\title{
Cytogenetic studies of human gametes, zygotes and preembryos
}

Citation for published version (APA):

Pieters, M. H. E. C. (1991). Cytogenetic studies of human gametes, zygotes and preembryos. [Doctoral Thesis, Maastricht University]. Rijksuniversiteit Limburg. https://doi.org/10.26481/dis.19911121mp

Document status and date:

Published: 01/01/1991

DOI:

10.26481/dis.19911121mp

Document Version:

Publisher's PDF, also known as Version of record

\section{Please check the document version of this publication:}

- A submitted manuscript is the version of the article upon submission and before peer-review. There can be important differences between the submitted version and the official published version of record.

People interested in the research are advised to contact the author for the final version of the publication, or visit the DOI to the publisher's website.

- The final author version and the galley proof are versions of the publication after peer review.

- The final published version features the final layout of the paper including the volume, issue and page numbers.

Link to publication

\footnotetext{
General rights rights.

- You may freely distribute the URL identifying the publication in the public portal. please follow below link for the End User Agreement:

www.umlib.nl/taverne-license

Take down policy

If you believe that this document breaches copyright please contact us at:

repository@maastrichtuniversity.nl

providing details and we will investigate your claim.
}

Copyright and moral rights for the publications made accessible in the public portal are retained by the authors and/or other copyright owners and it is a condition of accessing publications that users recognise and abide by the legal requirements associated with these

- Users may download and print one copy of any publication from the public portal for the purpose of private study or research.

- You may not further distribute the material or use it for any profit-making activity or commercial gain

If the publication is distributed under the terms of Article $25 \mathrm{fa}$ of the Dutch Copyright Act, indicated by the "Taverne" license above, 


\section{Cytogenetic studies of human}

\section{gametes, zygotes and preembryos}


$\div$ 


\section{Cytogenetic studies of human gametes, zygotes and preembryos}

\section{PROEFSCHRIFT}

ter verkrijging van de graad van doctor aan de Rijksuniversiteit Limburg te Maastricht, op gezag van de Rector Magnificus, Prof. Mr. M.J. Cohen volgens het besluit van het College van Dekanen, in het openbaar te verdedigen op donderdag, 21 november 1991 om 16.00 uur

door

Mathieu Hubertus Egidius Cornelus Pieters 


\section{Promotores:}

Prof. Dr. J.P.M. Geraedts

Prof. Dr. J.L.H. Evers

\section{Beoordelingscommissie:}

Prof. Dr. P.J. Brombacher, RL (voorzitter)

Prof. Dr. J.W. Arends, RL

Prof. Dr. J. Drukker, RL

Mw. Prof. Dr. C. Heyting, LUW

Prof. Dr. G.H. Zeilmaker, EUR

Pieters, Mathieu Hubertus Egidius Cornelus

Cytogenetic studies of human gametes, zygotes and preembryos / Mathieu Hubertus Egidius Comelus Pieters. -

Mastricht: Datawyse. - Ill.

Proefschrift Malastricht. - Met lit. opg. - Met

samenvatting in het Nederlands.

ISBN $90-529 \Perp 067-7$

NUGI 743

Trefw.: reproductieve genetica.

Druk: Datawyse Maastricht / Krips Repro Meppel

The study presented in this thesis was financially supported by the foundation for Medical and Health Research NWO (grant no. 900-504-067).

Het onderzoek waarop dit proefschrift is gebaseerd werd financieel gesteund door de Nederlandse organisatie voor Wetenschappelijk Onderzoek (subsidienr. 900-504067). 
Aan Lionne 



\section{CONTENTS}

Chapter I

General introduction

\section{Chapter II}

Cytogenetic analysis of in vitro fertilization (IVF) failures

\section{Chapter III}

Human gametes and zygotes studied by nonradioactive in situ hybridization

\section{Chapter IV}

Nonisotopic in situ hybridization as a method for nondisjunction studies in human spermatozoa

\section{Chapter V}

Immaturity and aneuploidy in human oocytes after different stimulation protocols

\section{Chapter VI}

Triploidy after in vitro fertilization:

cytogenetic analysis of human zygotes and embryos

\section{Chapter VII}

General discussion 


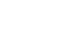
.

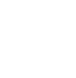

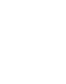

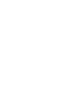

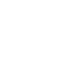

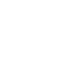

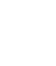

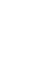

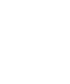
. . . . 
Chapter I

\section{General introduction}




\section{Introduction}

Of all human conceptions only $25 \%-30 \%$ progress successfully to delivery (Leridon, 1977). Early loss of pregnancy or fetal wastage may occur between fertilization and implantation, during the time of implantation, or after implantation at various stages of pregnancy. Only the latter are recognized as clinical abortions (Kline and Stein, 1985). Maternal infections, smoking, alcohol consumption, endocrine disorders, obstetric history, malformations of the reproductive system and (the lack of) immunological interactions between man and woman are bellieved to contribute to embryonic and fetal wastage (Edwards, 1986). However, chromosome abnormalities constitute the major cause of embryonic loss. In chromosome studies of spontaneous abortions abnormalities are encountered in about 50\% (Boue et al., 1975; Eiben et al., 1990). Both abortion rates and chromosome abnormalities are maternal age dependent. Age dependent abnormalities are a direct result of chromosomal nondisjunction during meiosis (Hook, 1981). Until 15 years ago, all events between ovulation and clinical pregnancy were hidden in a 'black box'. Thanks to the introduction of new reproductive techniques this area has become disclosed gradually and several windows of the 'box' have been opened. The development of in vitro fertilization (IVF) provided the opportunity to determine the frequency of chromosome abnormalities in human gametes and preembryos. With the birth of the world's first test-tube baby, Louise Brown, in 1978, a new era in the field of reproductive medicine commenced (Steptoe et al., 1980). From then onwards IVF and preembryotransfer have been developed into an established method for the treatment of infertility (Jones, 1986).

In the Netherlands 12 IVF centers are operational. Results of a prospective survey among five of these between august 1986 and june 1988 revealed that, whereas the rate of fertilization of human oocytes was relatively high $(\approx 65 \%)$, the rate of clinical pregnancies per transfer was only approximately $20 \%$, with an abortion rate of approximately $23 \%$ of the established clinical pregnancies (Haan, 1989). Compared to the 'in vivo' situation, IVF procedures, might give a higher incidence of embryonic failuire to implant or to develop beyond the preimplantation stage, because of the inherent asynchrony between transferred preembryos and endometrium (Lenton et al., 1988). One factor responsible for the failure to implant or for early developmental arrest may be the presence of lethal chromosome abnormalities. Theoretically, IVF is the procedure of choice to address the problem of chromosome abnormalities in human gametes, zygotes and preembryos. In the Netherlands however, because

\footnotetext{
'In this general introduction the words preembryo and embryo have the following meaning; preembryo: the early developmental stages between zygote and implantation.

embryo: the subsequent developmental stages of the inner cell mass of the preembryo after implantation
} 
of ethical and legal restrictions, human preembryos will only originate ir. the framework of infertility treatment, and therefore will hardly ever become available for investigation. For that reason in the present study only zygotes and preembryos were used which were not suitable for transfer to the uterus.

\section{Meiosis \& Gametogenesis}

Since sexual reproduction involves the combination of two gametes, without cell division leading to a reduced chromosome number in the oocytes and spermatozoa, the chromosome number of the offspring would be twice that of the parents.

During the meiotic process the diploid chromosome number $(2 \mathrm{n})$, as seen in somatic cells, is reduced to the haploid chromosome number (n) which is present in the germ cells. Meiosis can be divided in a first and second meiotic division, each with its own characteristics. For the process of chromosome division the spindle apparatus, consisting of contracting tubuli, is responsible. During the prophase of the first division, homologous chromosomes become arranged in pairs. During this phase the mechanism of crossing-over results in new combinations (recombination) of genes when exchanges take place between the nonsister chromatids of the homologous chromosomes. At the end of the first meiotic division (meiosis I) the homologous chromosomes migrate to opposite ends of the dividing nucleus, reducing the chromosome number from $2 \mathrm{n}$ to $\mathrm{n}$. "The second step is called meiosis II, at the end of which the centromeres are divided and the chromatids migrate to opposite poles. Because of the random combination of chromosomes and the crossing-over each of the meiotic products has a unique combination of genes (Figure 1 ).

During the process of gametogenesis (formation of the oocytes and the spermatozoa) not only the chromosome number is reduced from $2 n$ to $n$ but the germ cells undergo their maturation as well. During spermatogenesis (from the time of sexual maturity onwards), spermatogonia both divide as stem cells and give rise to more specialized cells (spermatocytes) by a series of mitoses. Each primary spermatocyte undergoing meiosis results in four unique spermatids which mature, without further division, into spermatozoa. In contrast to spermatogenesis, the process of oogenesis does not result in four mature gametes but only in one oocyte. In females, primary oocytes are resting in the prophase of meiosis 1 which is only completed at the time of ovulation. One of the daughter haploid chromosome sets is extruded and becomes the first polar body. The second meiotic division, which in the normal situation is only completed when the secondary oocyte is penetrated by a spermatozoon, results in the extrusion of the second polar body (Figure 2). 


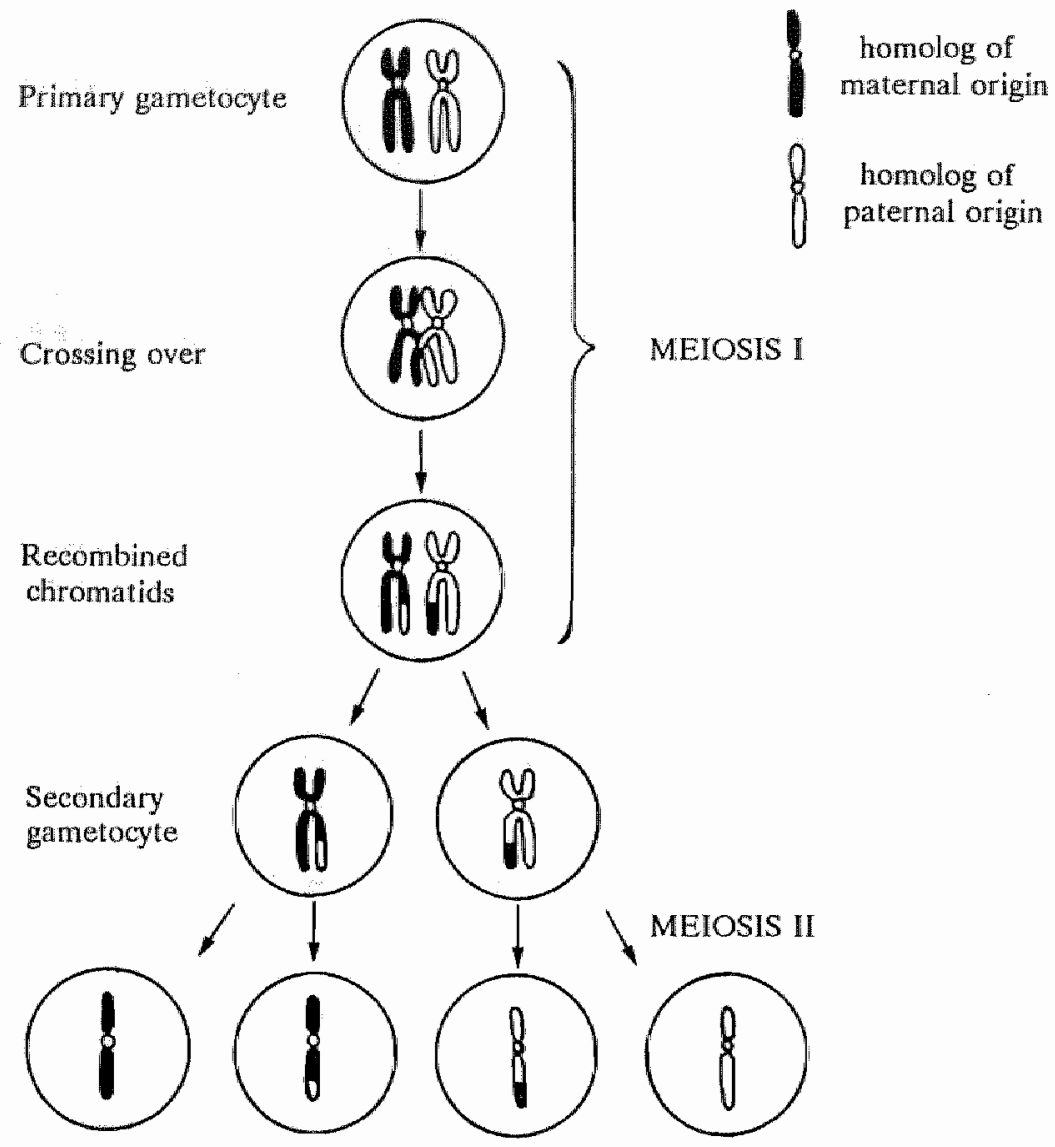

Figure 1. Schematic representation of chromosomal behavior during meiosis. One crossover between the long arms of one chromatid of each homologous chromosome is illustrated. 


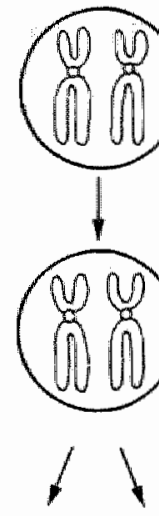

Primary gametocyte

\section{MEIOSIS I}
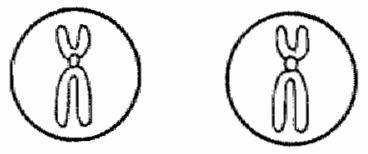

Secondary gametocyte

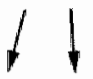<smiles>C1CC2=C3CCCC(C1)C3CC2</smiles><smiles>C1CCC2CCCCC2CC1</smiles><smiles>C1CC2CCC1C2</smiles>

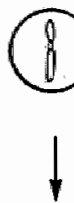

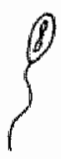<smiles>[I-][C@H]1C[In]1</smiles>

MEIOSIS II

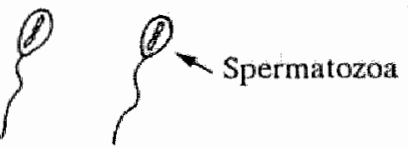

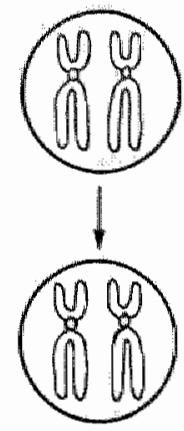
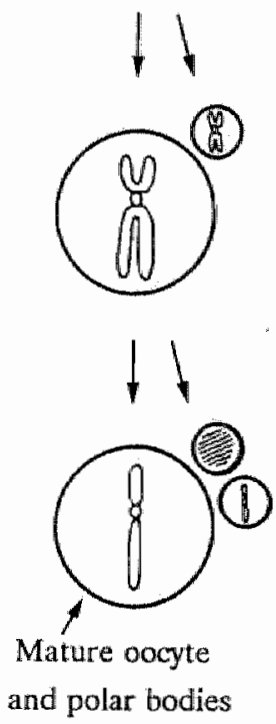

Figure 2. Outline of chromosomal behavior and distribution during gametogenesis.

\section{Fertilization and early development}

Fertilization can be defined as a process that begins with the fusion of the sperm and oocyte membranes and ends with the formation of the diploid zygote (Kline and Stein, 1985). Immediately after oocyte and sperm fusion the cortical granule reaction occurs and causes alterations in the chemical structure of the oocyte and its zona pellucida, and prevents polyspermy (Longo, 1989). During in vitro fertilization a strict 
sequence of events can be recognized. After entering the secondary oocyte, the sperm head rounds up and the nuclear material is decondensed to form the paternal pronucleus. Meanwhile, the second meiotic division of the oocyte is completed, resulting in two daughter nuclei which form the maternal pronucleus and the second polar body respectively. Soon after oocyte penetration by a spermatozoon, DNA synthesis starts and each chromosome consisting of a single chromatid is replicated. Both pronuclei approach one another and lose their membranes. Not more than 3-4 hours after pronuclei disappearance the maternal and paternal genomes form a common metaphase plate with the restored diploid chromosome number. The combined 46 chromosomes divide and migrate to opposite poles to form two daughter cells. This division is the first of a series of cleavage divisions which forms the start of preimplantation development (Figure 3).

\section{In vitro fertilization}

IVF, initially developed for women with tubal blockage, has also been proven suitable for the treatment of several other types of infertility also (Jones, 1986; Thatcher and DeCherney, 1989). In contrast to what is suggested by the name in vitro fertilization, it is not only the fertilization which takes place in vitro, but the early cleavage divisions of the preembryo as well. Thanks to IVF our knowledge of normal and abnormal events of fertilization and early preimplantation development (and of factors influencing these events) has expanded enormously.

There are as many different treatment modalities as there exist IVF centers. Therefore, only a general review of the IVF procedures is given here. After a short period of performing IVF in natural cycles, most centers have developed stimulation protocols to induce multiple follicular development, that are now more or less routine. The growth of follicles is monitored by ultrasound, and as additional parameters, serum or urine estrogen levels may be measured. Final maturation of the dominant follicles and ovulation is induced by the injection of human chorionic gonadotropin. Oocyte retrieval is performed 34 hours later, after which oocytes are allowed to mature for another 5 hours. In the mean time the semen of the partner is treated with a washing procedure to remove seminal plasma. By one of several available techniques a suspension of the most motile spermatozoa is obtained. Approximately 50,000 motile spermatozoa are added to each oocyte. After an incubation of 18-20 hours, investigation of the oocytes takes place to determine the number of pronuclei. Oocytes showing two pronuclei are cultured in fresh medium until preembryo transfer. Ongoing pregnancies have been achieved following preembryo transfer at different stages after fertilization varying from the 2-cell stage up to the blastocyst stage (Edwards and Steptoe, 1983; Trounson, 1983; Bolton et al., 1991). In our 
program up to four preembryos are transferred 40-44 hours after insemination, usually at the two- to four-cell stage. Supernumary preembryos are frozen.

A.

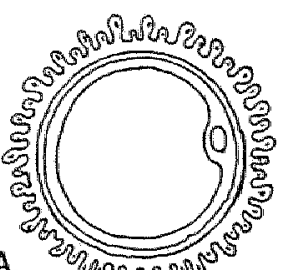

A.

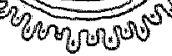

E.

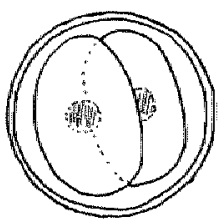

B.

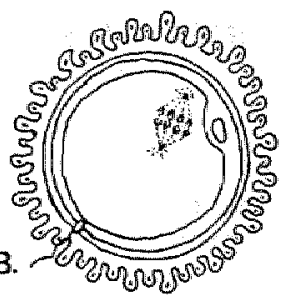

F.

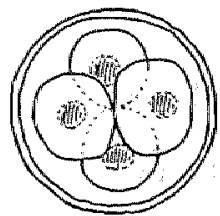

C.

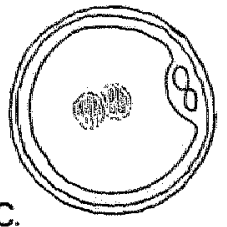

G.

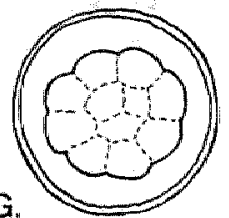

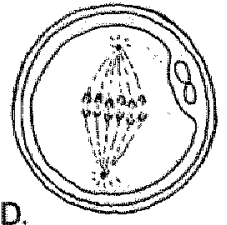

$\mathrm{H}$.

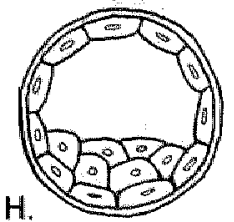

1.

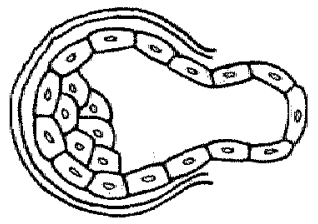

J.

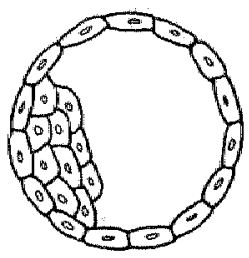

Figure 3. Drawings illustrating fertilization and early preimplantation development. A. Human oocyte surrounded by a corona radiata, first polar body is extruded. B. Sperm penetration and completion of second meiotic division. C. After sperm penetration two pronuclei appear and a second polar body is extruded. D. Syngamy of maternal and paternal genome. The first mitotic spindle of a diploid zygote is formed. E. Preembyo showing two blastomeres (two-cell). F. Four-cell preembryo. G. A ball of 16 - 32 cells called the morula. H. A cavity is formed and the morula is converting into a blastocyst. Inner cell mass clearly distinguishable from the trophectoderm cells. I. Preembryo cells bulging out of the zona pellucida, the process is called hatching. J. 'Hatched' preembryo just before implantation in the uterus. 


\section{Fertilization abnormalities}

Normal fertilization requires the occurrence, in a fixed sequence, of a number of delicate steps between sperm penetration and the first cleavage division. Under in vitro conditions the first signs of abnormal fertilization may be perceived at the time that the pronuclei should appear. If the number of pronuclei differs from two, a fertilization abnormality is likely.

Although the female gamete is brought together in close contact with high numbers of sperm cells in culture dishes, the process of fertilization does not result in a $100 \%$ success rate. IVF offers the opportunity to study fertilization failures. In theory, some of the fertilization failures may be due to a failure of the sperm cell to penetrate the oocyte. Other fertilization failures may be due to the absence of second polar body extrusion after spermpenetration. Meiosis II does not proceed beyond metaphase and no pronuclei will be observed in these cases. In case of normal pronuclear appearance, cleavage arrest may occur because of asynchronic development of parental nuclei.

Whereas non-fertilization is a main problem in IVF, the penetration and fertilization by more than one spermatozoon may occur as well. Regarding fertilization a remarkable difference exists between 'in vivo conditions' and 'in vitro conditions'. Whereas in the in vivo situation only a few sperms will reach the oocyte at the end of the female genital tract (Ahlgren, 1975), under laboratory conditions about 50,000 spermatozoa surround the oocyte. The development of polypronuclear (polyploid) zygotes varies between $2 \%$ and $9 \%$ of all inseminated oocytes (Mahadevan and Trounson, 1984; Al-Hasani et al., 1984; Macas et al., 1988). The number of pronuclei observed gives an indication of the number of gamete nuclei present in the zygote. Triploidy may be caused by a number of mechanisms. In certain instances the occurrence of triploidy may be explained by a delay in the cortical granule reaction or a breach in the zona pellucida allowing more than one spermatozoon to penetrate the oocyte (Kola and Trounson, 1989). In case of oocyte penetration by two sperms, dispermy, the zygote nucleus becomes triploid and contains three haploid chromosome sets instead of two. Another mechanism for the occurrence of triploidy is the combination of a normal haploid gamete with a diploid gamete, resulting from non-reduction during maternal or paternal meiosis. No systematic studies are available of the parental origin of triploidy in vitro. In abortion material, dispermy has been shown to play the most important role, whereas the additional chromosome complement is of maternal origin in a minority only (Jacobs et al., 1978). 


\section{Chromosomal abnormalities}

Chromosomal abnormalities are divided into those characterized by numerical changes (deviations from the normal number) and those characterized by structural changes (abnormalities of chromosome morphology). Numerical chromosome abnormalities involve the loss or gain of one or more chromosomes (aneuploidy) or even sometimes the gain of a whole chromosome set (polyploidy). The origin of polyploidy has been discussed in the paragraph on fertilization abnormalities. In the human, aneuploid and polyploid cells are frequently found in tissues from abortuses and stillbirths (Boué et al., 1975; Eiben et al., 1990). Whereas polyploidy is most frequently seen as a fertilization abnormality (occurring at the time of spermpenetration), aneuploidy is a chromosomal abnormality arising at the time of gametogenesis. As mentioned before, gametes contain a haploid chromosome set after meiotic division. Occasionally, during the reduction division a failure of chromosome separation (disjunction) may occur. If non-disjunction takes place, two homologous chromosomes migrate together towards the same pole. This division abnormality can take place during meiosis I and/or II (Figures 4 and 5). If the resulting gamete (containing one extra chromosome) unites

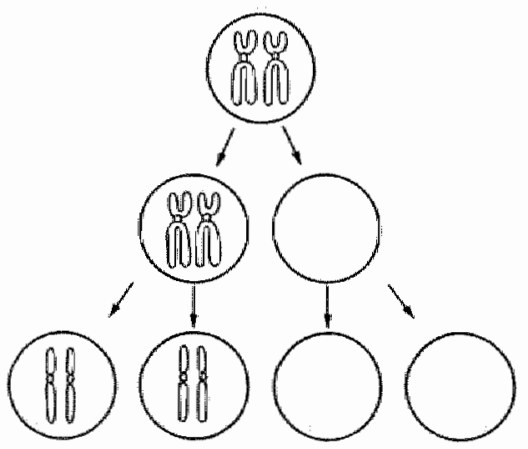

A. disomic gametes.

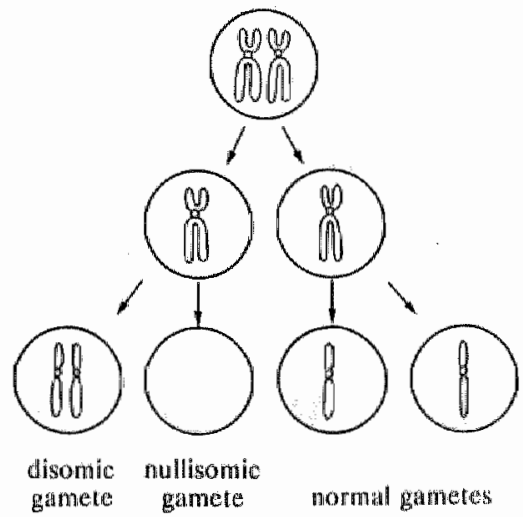

Figure 4. Diagrams illustrating nondisjunction. A: Nondisjunction at meiosis I; B: Nondisjunction at meiosis II.

with a normal gamete the result will be a zygote which is trisomic for that particular chromosome. The best known example is trisomy 21, causing Down's syndrome. As a counterpart to the cell with the extra chromosome, another cell will lack that particular chromosome. In case of fertilization of the latter with a normal gamete the zygote will be monosomic for that chromosome. Monosomy, with the exception of $45, \mathrm{X} 0$, appears to be lethal in the human. Although a relationship has been shown between maternal age (and therefore age of the oocytes) and 
the occurrence of non-disjunction, numerical chromosome abnormalities may also be found in spermatozoa. Another source of numerical abnormalities is anaphase lagging, a situation in which one or more chromosome(s) are not included in the daughter cell(s). Structurally abnormal chromosomes with numbers of centromeres not equal to one (i.e., either acentric or dicentric) are usually eliminated by this mechanism.

Stable structural abnormalities may result from two or more breaks in the DNA strands of one or more chromosomes leading to deletions, inversions and translocations.
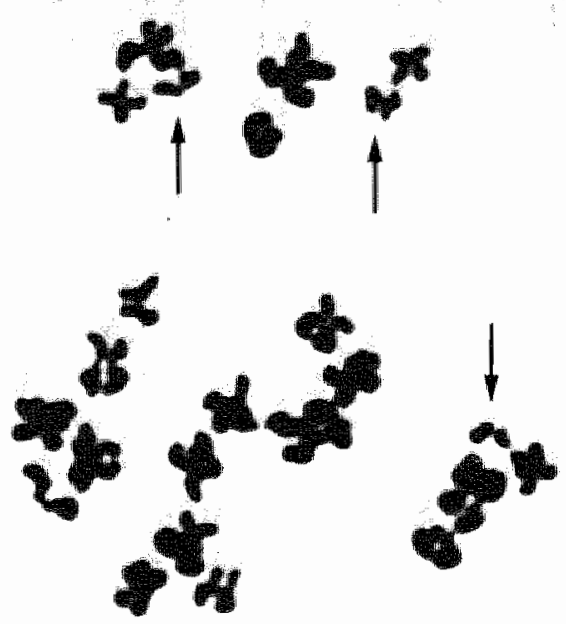

Figure 5. Metaphase II chromosome. set of a human oocyte. Nondisjunction occurred in the first meiosis resulting in an extra Ggroup chromosome (see arrows). 


\section{Cytogenetic techniques}

In 1966 Tarkowski introduced an air-drying method for chromosome preparations from mouse oocytes. Fortunately, unfertilized oocytes are 'arrested' in metaphase II and chromosome spreads may be obtained rather easily. Since no nuclear membrane is present at metaphase, the chromosomes are free to 'swim' around. Treating cells with a hypotonic solution will increase the size of the 'swimming pool' and after fixation successful chromosome spreads may be obtained. After the oocytes are incubated in the hypotonic solution, a microdrop of this solution containing the oocyte is placed on a grease-free slide. Thereafter a few drops of fixative are added. With some modifications this rather simple method has been adopted by many investigators. Somatic cells only very rarely expose metaphase spreads (mitosis chromosomes) when fixed without pretreatment. The same holds for preembryos.

Colchicine has the property of preventing the formation of the spindle and arresting mitosis at the metaphase stage (Blakeslee and Avery, 1937). At this stage the chromosomes are contracted maximally and defined most clearly. Also zygotes and preembryos can be treated in this way to obtain metaphase spreads.

The original chromosome classification was devised in 1960 at a meeting of cytogeneticists in Denver, Colorado (ISCN, 1985). This 'Denver classification" distinguishes seven chromosome groups, identified by the letters $A$ through $G_{x}$ on the basis of their overall length and centromere position. With more advanced staining methods the chromosomes can be identified individually. There exist essentially four different staining techniques, named after the method Q- (quinacrine), G- (Giemsa), R(reverse) and $\mathrm{C}$ - (centromere) banding method. Each technique requires the treatment of the chromosome spreads before staining with a different regimen. Metaphase II chromosomes of human oocytes are strongly condensed and less suitable for either of the four staining techniques. Without pretreatment, oocyte chromosomes are uniformely stained and can be classified in groups A-G according to the Denver chromosome classification. Human preembryos can also be stained with the dystamicin/DAPI method (Schweizer et al., 1978) to obtain specific chromosome staining. In this way chromosomes $1,9,15,16$, and the $Y$-chromosome may be distinguished.

The recent introduction of DNA techniques in cytogenetic analysis gives the opportunity to investigate chromosomes not only in metaphase spreads but in interphase nuclei as well. In situ hybridization allows identifying specific parts of the genome known as target DNA. Chemically modified or labeled chromosome specific probes (pieces of DNA strands) are hybridized with the target DNA. Following their hybridization onto target DNA sequences, these probes can be visualized in different ways immunocytochemically using fluorochromes as reporter molecules (Figure 6). Whether it is possible (using chromosome specific 
DNA probes and in situ hybridization techniques) to evaluate the chromosomal content of cells involved in in vitro fertilization, solely on the basis of interphase nuclei, was one of the scopes of this thesis.

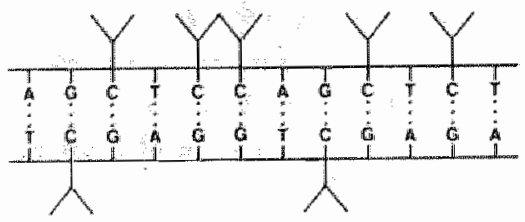

modified DNA $=$ probe

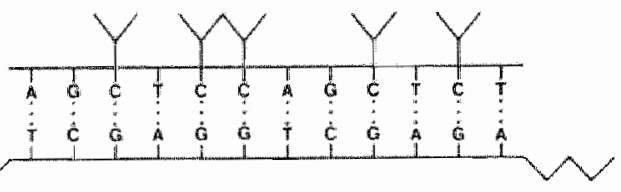

hybrid of probe and target DNA

FITC conjugated goat-anti-mouse IgG

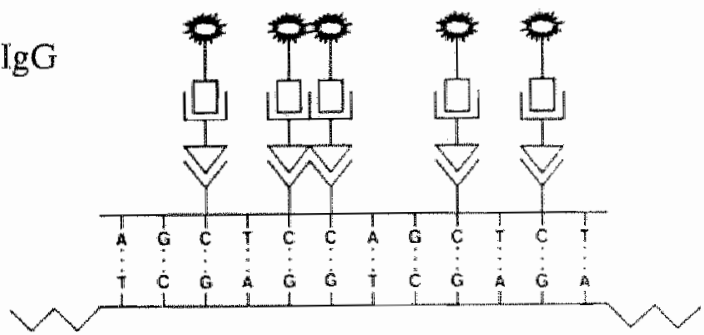

mouse monoclonal anti-modified-DNA

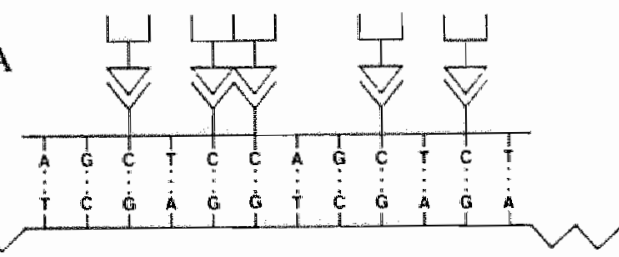

Figure 6. Scheme for hybridization and immunocytochemical detection of target DNA. 


\section{Aims of this study}

This study was initiated to examine oocytes at the time of in vitro fertilization and during their subsequent development and was especially focussed on abnormalities, i.e., unfertilized oocytes and other IVF failures. The aims of this study were:

1. To study sperm penetration, aspects of fertilization and chromosome condensation in human oocytes considered to be unfertilized in an IVF program (Chapter II).

2. To develop a method of fluorescence in situ hybridization to study gametes, zygotes, and preembryos as an alternative method for chromosomal studies (Chapter III).

3. To study chromosomal non-disjunction in spermatozoa of a series of normal partners of women with an indication for in vitro fertilization, using ISH (Chapter IV).

4. To compare the influence of different stimulation protocols on the maturity of unfertilized oocytes and to compare the aneuploidy ratios of these oocytes (Chapter V).

5. To study the ploidy of preembryos resulting from tripronuclear zygotes. The attention is not only focused on triploidy but especially on the cleavage divisions resulting in mosaicism (Chapter VI).

\section{References}

Ahlgren M: Sperm transport to and survival in the human fallopian tube. Gynecol Invest 6:206-214, 1975

Al-Hasani S, Ven van de $\mathbf{H}$, Diedrich $\mathbf{K}$, Hamerich $U$, Lehmann $F$, Krebs D: Polyploidien bei der In-vitro-fertilisation menschlicher Eizellen: Häufigkeit und mögliche Ursachen. Geburtsh u Frauenheilk 44:395-399, 1984

Blakeslee AF, Avery AG: Methods of inducing doubling of chromosomes in plants. J Hered 28:392-411, 1937

Bolton VN, Wren ME, Parsons JH: Pregnancies after in vitro fertilization and transfer of human blastocyst. Fertil Steril 55:830-832, 1991

Boué J, Boue A, Lazar P: Retrospective and prospective epidemiological studies of 1500 karyotyped spontaneous human abortions. Teratology, 12:11-26, 1975

Edwards RG and Steptoe PC: Current status of in vitro fertilisation and implantation of human embryos. Lancet 2:1265-1269, 1983

Edwards RG: Causes of early embryonic loss in human pregnancy. Human Reprod $1: 185-198,1986$ 
Eiben B, Bartels 1, Bâlur-Porseh S, Borgmann $\mathrm{S}$, Gatz G, Gellert $\mathrm{G}$, Goebel R, Hammans $W_{\text {, Hentemann }} \mathbf{M}_{\text {, Osmers }} \mathbf{R}$, Rauskolb $\mathbf{R}$, Hansmann I: Cytogenetic analysis of 750 spontaneous abortions with the direct-preparation method of chorionic villi and its implications for studying genetic causes of pregnancy wastage. Am J Hum Crenet, 47:656-663, 1990

Haan GHMG: Effekten en kosten van in vitro fertilisatie. Een prospektieve multicenter studie. Thesis, Maastricht, 1989

Hook EB: Rates of chromosome abnormalities at different maternal ages. Obstet Gynaecol 58: 282-285, 1981

ISCN: An International System for Human Cytogenetic Nomenclature, Harnden DC, Klinger HP (eds); Published in collaboration with Cytogenet Cell Genet. Karger, Basel (1985); also in Birth Defects: Original Article Series, Vol 21, No 1 (March of Dimes Birth Defects Foundation, New York 1985)

Jacobs PA, Angell RR, Buchanan IM, Hassold TJ, Matsuyama AM, Manuel B: The origin of human triploids. Ann Hum Genet (Lond.) 42:49-57, 1978

Jones HW jr: The infertile couple. In: Fishel S, Symonds EM (eds) In vitro fertilisation. Past-present-future. IRL press, Oxford Washington DC, pp 17-26, 1986

Kline J, Stein Z: Very early pregnancy. In Dixon RL (ed) Reproductive toxicology. Rawen Press, New York, pp 251-265, 1985

Lenton EA, Osborn J, Colman C, Fothergill D: Premenstrual pregnancy loss. A significant contribution to the low pregnancy rates following in vitro fertilization. Ann NY Acad Sci 541:498-509, 1988

Leridon H: Human Fertility. University of Chicago press, Chicago, 1977

Longo FJ: Egg cortical architecture. In: Schatten H, Schatten G (eds) The cell biology of fertilization. Academic press, San Diego, California pp 105-138, 1989

Macas E, Suchanek E, Grizelji V, Puharic I, Simunic V: Chromosomal preparations of human triploid zygotes and embryos fertilized in vitro. Eur J Obstet Gynecol \& Reprod Biol 29:299-304, 1988

Mahadevan MM, Trounson AO: The influence of seminal characteristics on the success rate of human in vitro fertilization. Fertil Steril 42:400-405, 1984

Schmiady H, Kentenich H, Stauber M: Chromosome studies of human in vitro fertilization (IVF) failures. In: Obe $G$, Basler A (eds) Cytogenetics. Basic and applied aspects. Springer Verlag, Berlin Heidelberg, pp 184-197, 1987

Schweizer D, Ambros P, Andrle M: Modification of DAPI banding on human chromosomes by prestaining with a DNA-binding olipeptide antibiotic, dystamicin A. Exp Cell Res 111:327-332, 1978

Steptoe PC, Edwards RG, Purdy J: Clinical aspects of pregnancies established with cleaving embryos grown in vitro. $\mathrm{Br} \mathbf{J}$ Obstet Gynaecol, 87:757-768, 1980 
Tarkowski AK: An air-drying method for chromosome preparations from mouse eggs. Cytogenetics 5:394-400, 1966

Thatcher SS, DeCherney AH: A critical assessment of the indications for in vitro fertilization and embryo transfer. Human Reprod 4, suppl..11-16, 1989

Trounson A: Factors controlling normal embryo development and implantation of human oocytes fertilized in vitro. In: Beier HM, Lindner HR (eds) Fertilization of the human egg in vitro: biological basis and clinical applications. Springer-Veriag, Berlin Heidelberg New York, pp 233-246, 1983 



\section{Chapter II}

\section{Cytogenetic analysis of in vitro fertilization (IVF) failures}

M.H.E.C. Pieters, ${ }^{1}$ J.P.M. Geraedts, ${ }^{1}$ J.C.M. Dumoulin, ${ }^{1,2}$ J.L.H. Evers, ${ }^{2}$ M. Bras, ${ }^{1,2}$ F.H.A.C. Kornips, ${ }^{1}$ and P.P.C.A. Menheere ${ }^{3}$

1. Department of Genetics and Cell Biology, University of Limburg, Maastricht, The Netherlands.

2. Department of Obstetrics and Gynaecology,

3. Department of Clinical Chemistry, Academic Hospital Maastricht, The Netherlands.

Human Genetics 81, 367-370, 1989. 


\section{Summary}

Cytogenetic studies were carried out on 150 oocytes obtained in a human in vitro fertilization (IVF) program. Although all cells lacked signs of fertilization at light microscopy, $46(30.7 \%)$ appeared to show cytological evidence of fertilization. At least one-third of these cells (with development arrested before first cleavage) had chromosomal aberrations. An aneuploidy rate of $35 \%$ was found in unfertilized oocytes. The results of this study explain some of the fertilization failures and of the failures of post-fertilization development.

\section{Introduction}

The incidence of chromosome aberrations in spontaneous human abortions is well documented (Boue et al. 1975; Hassold et al. 1980). This contrasts with the lack of data on chromosomal abnormalities in human gametes and in zygotes or preembryos. The use of zona-free hamster oocytes has made possible the determination of spermatozoal chromosome abnormalities (Martin et al. 1983; Kamiguchi and Mikamo 1986), and with the introduction and development of IVF treatment, it has become possible to study human oocytes. However, the results of the first studies were not consistent; data on chromosomal abnormalities varied from $11 \%$ (Spielmann et al. 1985) to $65.4 \%$ (Wramsby and Fredga 1987). Since only few preembryos implant in the uterus after fertilization in vitro (Rogers et al. 1986a), it may be expected that selection against aneuploid conceptuses takes place during the preimplantation and early postimplantation period. Here we report the results of a study of human oocytes considered to be unfertilized. Attention was focused upon the various chromosome condensation stages and upon the occurrence of aneuploidy and polyploidy.

\section{Materials and methods}

Material for this study was obtained from a series of 157 patients, in whom IVF was carried out for the following indications: tubal pathology (97), male infertility (15), unexplained infertility (25), anti-sperm-antibodies (7), cervical hostility (5), and endometriosis (8). Clomiphenecitrate and human menopausal gonadotropin (HMG) were used to induce superovulation. Follicle growth was monitored by ultrasound and by determination of serum $17-\beta$-estradiol $\left(E_{2}\right)$ from day 8 onwards until a mean diameter of the dominant follicle of $16 \mathrm{~mm}$ was reached. Laparoscopic or ultrasound-guided oocyte retrieval was performed 32-34 $\mathrm{h}$ after human chorionic gonadotropin (HCG) injection.

Whittingham's T6 medium supplemented with $15 \%$ patient serum was 
used during preincubation and insemination of the oocytes. The oocytes were usually preincubated for $5 \mathrm{~h}$ and about 50000 motile sperm were added to the oocyte in $1 \mathrm{ml}$ medium in a 4-well multidish (Nunc). About $20 \mathrm{~h}$ after insemination the cumulus cells were mechanically removed, and the oocytes were examined for the presence of pronuclei and transferred to fresh medium. Culture was continued for another 20-24 h. Embryo transfer was performed 40-44 h after insemination.

Cytogenetic analysis was performed on oocytes that were considered to be unfertilized because they did not exhibit pronuclei $20-24 \mathrm{~h}$ after insemination and, in addition, did not cleave within $48 \mathrm{~h}$. Chromosome preparation of the oocytes was performed according to a modification of the air-drying technique of Tarkowski (1966). The oocyte was placed in a hypotonic (1\%) sodium-citrate solution for about 15 minutes. Subsequently the oocyte was placed in a microdrop of the same solution on a grease-free slide. Most of the solution was carefully removed. Gradual fixation was done in three steps: first a drop of $\pm 100 \%$ methanol and rapidly after this, a drop of an acetic acid/methanol $(\mathrm{v}: \mathrm{v}=1: 5)$ solution, and finally a drop of an acetic acid/methanol $(v: v=1: 3)$ solution were placed on the oocyte. The slide was dried and preparations were stained in a $10 \%$ Giemsa solution. Chromosomes of human sperm and of metaphase II-arrested oocytes were identified as described by Plachot et al. (1987), and polar body chromosomes were identified as described by Wramsby and Liedholm (1984).

\section{Results}

The in vitro fertilization treatment of 157 patients resulted in 752 oocytes, $406(54.0 \%)$ of which were fertilized (including the multipronuclear zygotes). Cytogenetic analyses were attempted on 285 oocytes showing no pronuclei or cleavage, 150 of which $(52.6 \%)$ were informative. The results obtained for the several indication groups for IVF are not reported separately since individual groups were too small to allow for statistical testing. 


\section{Fertilized oocytes}

Findings from all 150 oocytes of the IVF failures are summarized in Table 1. Forty six $(30.7 \%)$ showed findings inconsistent with the original interpretation that they were unfertilized. Seven oocytes showed one set of mitotic chromosomes, varying in number between 15 and 48 . According to the mitotic aspect, these oocytes must have been fertilized, but further development was arrested before first cleavage. We have no explanation for the finding of six oocytes showing two to four highly spread and weakly stained oocyte interphase nuclei, clearly different from interphase nuclei of corona cells, which are smaller and have a more intense aspect. In 27 cytologic preparations, oocyte metaphase II (MF II) chromosomes were found besides one or more sets of condensating chromosomes. Of these oocytes 17 showed one grossly haploid MF II chromosome set and one set of condensating sperm chromosomes. Figure 1 shows these chromosomes in early, mid, or late prophase. Ten oocytes considered to be unfertilized appeared to be polyploid (6.7\%). Eight of these were triploid: either one extra maternal (6) or paternal (2) set of chromosomes was found. The remaining two were tetraploid: on the basis of the chromosome morphology and of the presence of a clearly recognizable set of polar body chromosomes, all extra sets were presumed to be of paternal origin (Figure 2). Six preparations did not show enough detail for appropriate analysis, but the number and aspect of the chromosomes indicated that they most probably were derived from fertilized oocytes.

\section{Unfertilized oocytes}

Because of the possibility of artificial chromosome loss, highly dispersed, hypohaploid (i.e., containing less than 23 chromosomes) metaphases were placed in the category "grossly haploid", as were the metaphases that had too many overlapping chromosomes. In the group of 104 unfertilized oocytes, $65(62.5 \%)$ were categorized grossly haploid. Of these oocytes 28 $(26.9 \%)$ were countable. Ten unfertilized oocytes showed a grossly diploid number of chromosomes. Because of the meiotic aspect of the chromosomes, retention of the first polar body had to be presumed, and therefore these cells were in fact primary oocytes. 
Table 1. Findings in 150 IVF failures. See text for explanation

Fertilized

metaphase nucleus

interphase nuclei

gamete nuclei ( 1 secondary oocyte +1 sperm)

gamete nuclei (1 secondary oocyte +2 sperms)

gamete nuclei (1 primary oocyte +1 sperm)

gamete nuclei ( 1 secondary oocyte +3 sperms)

unclassifiable

Unfertilized

grossly ${ }^{a}$ haploid secondary oocyte

aneuploid $(>23, \mathrm{X})$ secondary oocyte

grossly diploid (primary oocyte)

a could not be counted exactly

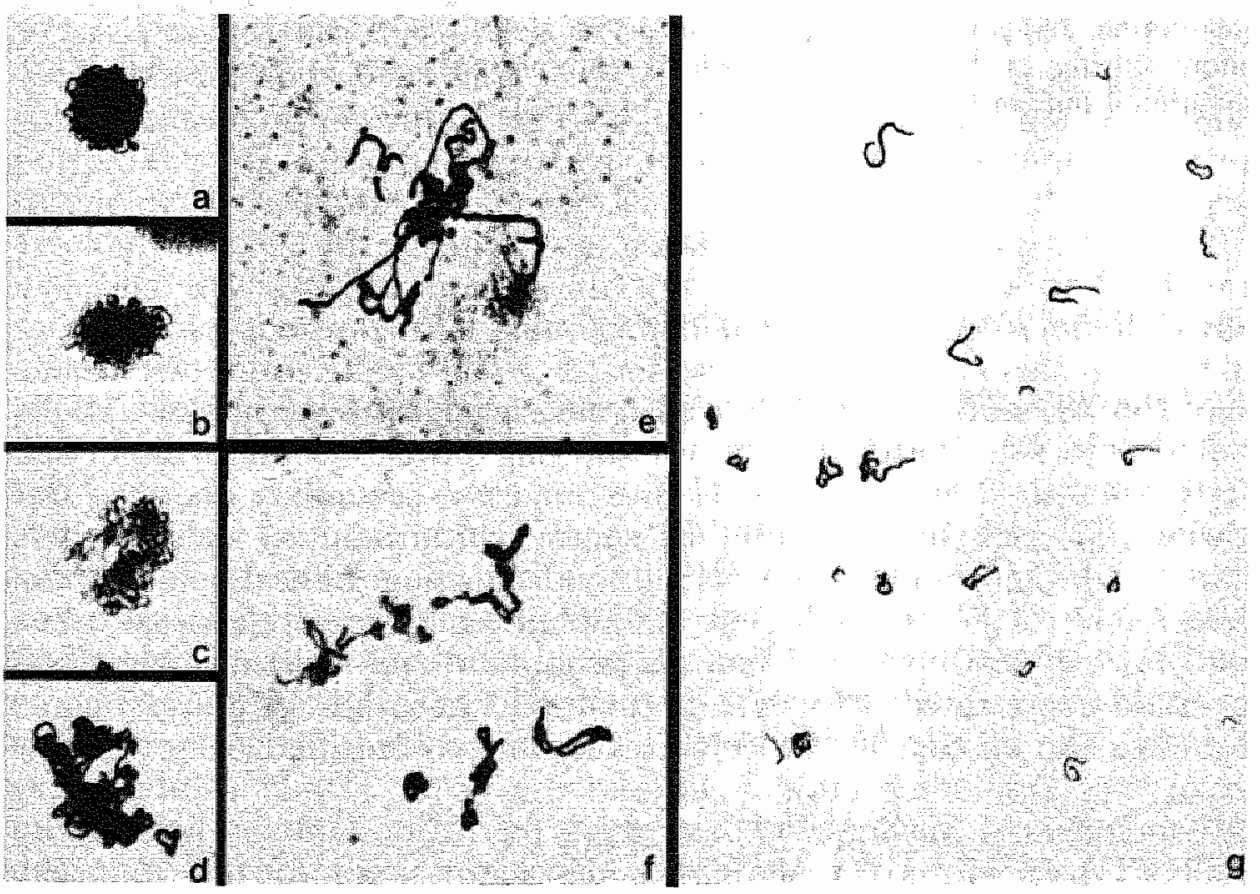

Figure 1 a-g. Condensating human sperm chromosomes in: a-d early; e,f mid; and $\mathbf{g}$ late prophase. 


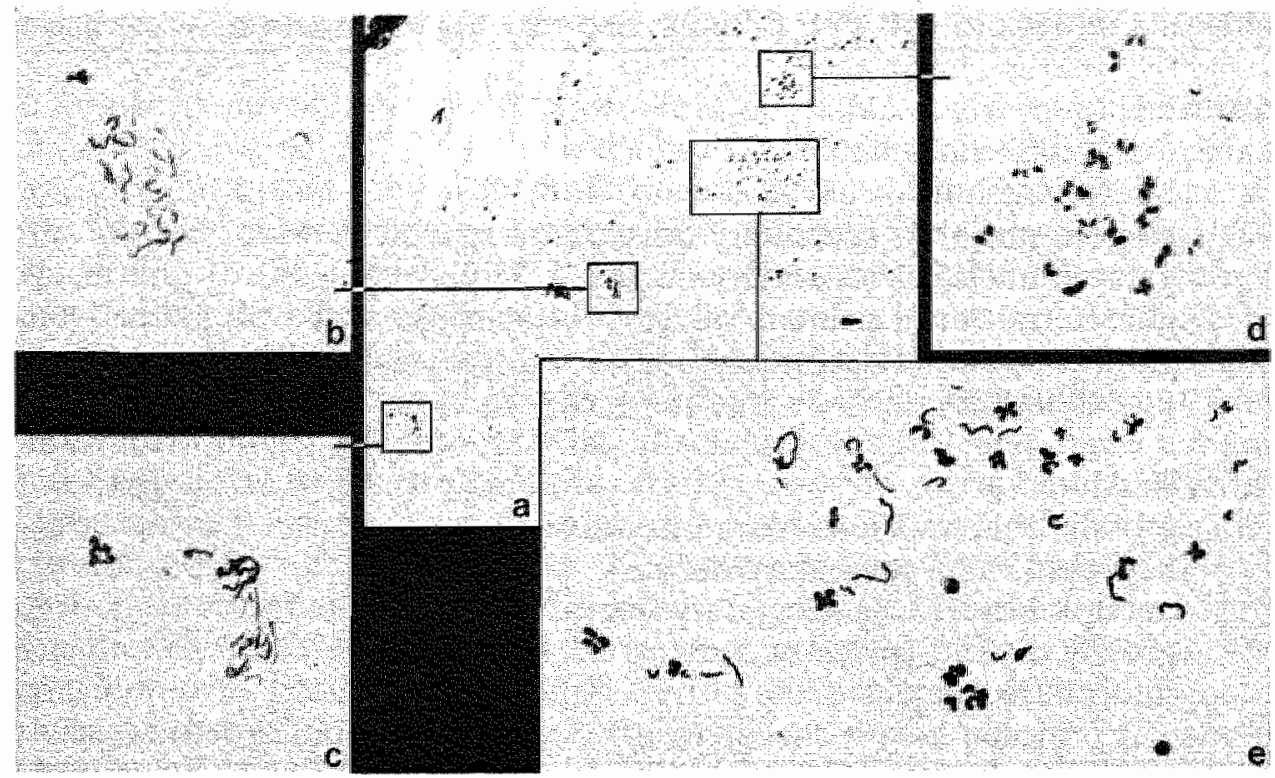

Figure 2. A human oocyte penetrated by three spermatozoa: a overall picture; b,c condensating human sperm chromosomes; d polar body chromosomes; and e random mixing of human oocyte MF II chromosomes $(23, X)$ and a set of 22 condensated human sperm chromosomes.

\section{Numerical and structural abnormalities}

Six of the 28 analyzable unfertilized cases showed a hyperhaploid MF II chromosome set. Within the group showing proof of fertilization, one oocyte showed 48 mitotic chromosomes, and two secondary oocytes (also showing one set of condensating sperm chromosomes) were hyperhaploid. Chromosomes involved in nondisjunction either belonged to group $\mathrm{C}, \mathrm{D}$, or $\mathrm{G}$ or could not be identified. Chromatid breaks were found in 9 of 150 oocytes. From all penetrated spermatozoa only three sets could be counted: two were normal, and one showed only 22 chromosomes. The missing chromosome could not be identified. 


\section{Discussion}

As shown in earlier studies, the chromosomes of male and female gametes have quite different aspects in developmentally arrested zygotes. Male and female genomes can be identified on the basis of chromosome condensation. The process leading to condensation of human sperm chromosomes has been described by Schmiady et al. (1986). In "prophasing" sperm cells, chromosomes condense into single chromatids, which are usually as long as mitotic chromosomes (Schmiady and Sperling 1981). When syngamy does not occur, human sperm chromosomes can be seen as single chromatids, whereas metaphase II-arrested oocytes show chromosomes with double chromatids (Santaló et al. 1986; Plachot et al. 1987).

Faillure of postfertilization development was present in 46 of 150 oocytes $(30.7 \%)$. Fertilization in oocytes considered to be unfertilized has also been found by other investigators. In one study, Mettler and Michelmann (1985) showed that 15 of 49 undivided oocytes were diploid and three were polyploid $(36 \%)$, which agrees with our figure of $30.7 \%$. Plachot et al. (1987) showed sperm chromosomes in 7 of $26(27 \%)$ primary oocytes and in 19 of $125(15.2 \%)$ secondary oocytes. Also these figures compare well with those found in our study: 6 of $16(37.5 \%)$ primary oocytes and 17 of $110(15.4 \%)$ secondary oocytes showed one set of condensating sperm chromosomes. Plachot et al. (1987) also observed a double set of sperm chromosomes in 5 of 151 oocytes (3.3\%). In this evaluation polyploidy was caused four times by fertilization with more than one sperm or with a diploid sperm. This constitutes $2.7 \%$ of all oocytes. Triploidy in this investigation was caused six of eight times by an extra maternal set. This contrasts with the results from studies on human spontaneous abortions that showed that triploidy is caused by diandry in almost two-thirds of all cases, as reflected by the presence of an extra paternal set of chromosomes (Meulenbroek and Geraedts 1982; Uchida and Freeman 1985).

When single cells are dealt with, it is not possible to ascertain that chromosomes are not being lost. The question of reliability of the number of chromosomes is one of the most important questions in analyzing oocyte metaphases. At this time it is not clear whether the finding of less than 23 chromosomes is real or an artifact. The reliability of finding $23 \mathrm{MF}$ II specific chromosomes can be documented by karyotyping: loss of chromosomes is unlikely if all the groups A-G (Denver classification) (ISCN 1985) are present. Chromosome loss due to the preparation method might be prevented by applying a technique that does not disrupt the cytoplasmic membrane (Wramsby and Liedholm 1984). However, a disadvantage of such a technique is the poor quality of chromosome spreading, which at this moment is the most common cause of analytical difficulties. With 6 hyperhaploid metaphases in a total number of 28 countable unfertilized oocytes $(21.4 \%)$, the total percentage 
of aneuploidy can be calculated assuming that each hyperhaploid cell has a hypohaploid cell as a counterpart. The (maximum) number of abnormalities is then $(6+6): 34=35.3 \%$. Most probably the real percentage of aneuploidy is in between the observed and the calculated figures. The latter rate is comparable to the rates of $32 \%$ and $48 \%$ published by Plachot et al. (1987) and by Wramsby et al. (1987), respectively. Of the 46 oocytes showing signs of fertilization, at least one third was abnormal: 6 [twice the number (3) of hyperhaploid cells] were aneuploid, and 10 were polyploid.

The results of our investigation explain some of the failures of IVF. From a large series of IVF treatments (Rogers et al. 1986b) it is known that on the average only $60 \%$ of the oocytes show signs of fertilization, i.e., pronuclei and/or cleavage. Since it is clear that almost one-third of apparently unfertilized oocytes are abnormal, it is suggested that many failures result from selection against aneuploid and polyploid conceptuses at the time of or shortly after fertilization. Information on the fertilization rate and repeated cytologic proof of fertilization in supposedly unfertilized oocytes may have prognostic value for individual patients.

\section{Acknowledgements}

The authors wish to thank Francis van der Lubbe for her excellent photography. This investigation has been supported by the foundation for Medical and Health Research Medigon (grant no. 900-504-067).

\section{References}

Boué J, Boué A, Lazar P (1975) Retrospective and prospective epidemiological studies of 1500 karyotyped spontaneous human abortions. Teratology 12:11-26

Hassold T, Chen N, Funkhauser J, Jooss T, Manuel B, Matsuura J, Wilson C, Yamane JA, Jacobs PA (1980) A cytogenetic study of 1000 spontaneous abortions. Ann Hum Genet 44:151-178

ISCN (1985) An International System for Human Cytogenetic Nomenclature, Harnden DG and Klinger HP (eds); published in collaboration with Cytogenetic Cell Genet (Karger, Basel 1985)

Kamiguchi Y, Mikamo K (1986) An improved, efficient method for analyzing human sperm chromosomes using zona-free hamster ova. Am J Hum Genet 38:724740

Martin RH, Balkan W, Burns K, Rademaker AW, Lin CC, Rudd NL (1983) The chromosome constitution of 1000 human spermatozoa. Hum Genet 63:305-309 
Mettler L, Mïchelmann HW (1985) Chromosome studies of early human embryos: proof of fertilization in uncleaved human oocytes. Ann NY Acad SC 442:458-465

Mealenbroek GHM, Geraedts JPM (1982) Parental origin of chromosome abnormalities in spontaneous abortions. Hum Genet 62:129-133

Plachot M, de Grouchy J, Junca AM, Mandelbaum J, Turleau C, Couillin P, Cohen J, Salat-Baroux J (1987) From oocyte to embryo: a model, deduced from in vitro fertilization, for natural selection against chromosome abnormalities. Ann Génét (Paris) 30:22-32

Rogers PWA, Milne BJ, Trounson AO (1986a) A model to show human uterine receptivity and embryo viability following ovarian stimulation for in vitro fertilization. J In Vitro Fert Embryo Transfer 3:93-98

Rogers P, Molloy D, Healy D, McBain J, Howlett D, Bourne H, Thomas H, Wood C, Johnstion I, Trounson A (1986b) Cross-over trial of superovulation protocols from two major in vitro fertilization centers. Fertil Steril 46:424-431

Santal6 J, Estop AM, Egozcue J (1986) The chromosome complement of firstcleavage mouse embryos after in vitro fertilization. J In Vitro Fert Embryo Transfer 3:99-105

Schmiady H, Sperling K (1981) Length of human prematurely condensed chromosomes during $\mathrm{G}_{0}$ and $\mathrm{G}_{1}$ phase. Exp Cell Res 134:461-465

Schmiady $H$, Sperling $K$, Kentenich $H$, Stauber $M$ (1986) Prematurely condensed human sperm chromosomes after in vitro fertilization (IVF). Hum Genet 74:441443

Spielmann H, Krüger C, Stauber M, Vogel R (1985) Abnormal chromosome behavior in human oocytes which remained unfertilized during human in vitro fertilization. J In Vitro Fert Embryo Transfer 2:138-142

Tarkowski AK (1966) An air-drying method for chromosome preparation from mouse eggs. Cytogenetics 5:394-400

Uchida IA, Freeman VCP (1985) Triploidy and chromosomes. Am J Obstet Gynecol 151:65-69

Wramsby H, Fredga K (1987) Chromosome analysis of human oocytes failing to cleave after insemination in vitro. Hum Reprod 2:137-142

Wramsby H, Liedholm P (1984) A gradual fixation method for chromosomal preparations of human oocytes. Fertil Steril 41:736-738

Wramsby $H$, Fredga $K$, Liedholm P (1987) Chromosome analysis of human oocytes recovered from preovulatory follicles in stimulated cycles. $N$ Engl $J$ Med 316:121124 


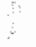




\section{Human gametes and zygotes studied by nonradioactive in situ hybridization}

M.H.E.C. Pieters, ${ }^{1}$ J.P.M. Geraedts, ${ }^{1}$ H. Meyer, ${ }^{1}$ J.C.M. Dumoulin, ${ }^{1,2}$ J.L.H. Evers, ${ }^{2}$ R.J.E. Jongbloed, ${ }^{1}$ P.M. Nederlof, ${ }^{3}$ and S. van der Flier ${ }^{3}$

1. Department of Genetics and Cell Biology, University of Limburg, Maastricht,

2. Department of Obstetrics and Gynaecology, Academic Hospital Maastricht,

3. Department of Cytochemistry and Cytometry, Sylvius Laboratory, Leiden University, Leiden (The Netherlands)

Cytogenetics Cell Genetics 53, 15-19, 1990. 


\section{Abstract}

A nonradioactive in situ hybridization technique was applied to human gametes and abnormally fertilized or developed zygotes. Using haptenized chromosome-specific probes, visualization was obtained using immunocytochemistry to achieve a fluorescent stain on specific hybrids. Using a chromosome 1-specific DNA probe, almost all spermatozoa gave a positive result, i.e., one hybridization signal per cell could be observed. Furthermore, it was possible to identify sperm cells with two spots, suggesting nondisjunction. Two cleavage arrested embryos from different patients showed both: two brightly fluorescent spots and two weaker spots with the same DNA probe. Using a Y-specific DNA probe the percentages of positive spermatozoa from the normal males ranged between $48.1 \%$ and $49.1 \%$. In an embryo with four grossly haploid chromosome sets, three fluorescent spots were obtained with the Yspecific DNA probe, indicating the penetration of three spermatozoa.

\section{Introduction}

Since the introduction of in situ hybridization (Gall and Pardue, 1969; John et al., 1969), the technique has been used for the localization of DNA sequences in interphase and metaphase nuclei from many different cell types. In the seventies, the first methods were developed to overcome the disadvantages of the original autoradiographic method, notably, the low resolution and the long exposure times needed. This resulted in the use of biotinylated DNA probes (Langer et al., 1981) and fluorescence visualization of the DNA-DNA hybrids (Manuelidis et al., 1982). Advantages of the latter method are the use of nonisotopically labeled probes and a signal that can be generated in a few hours.

Recent in situ hybridization studies (using chromosome-specific DNA probes) have demonstrated the applicability of this technique in prenatal diagnosis (Cremer et al., 1986) and in the detection of numerical and structural chromosomal abnormalities in tumor cell lines (Cremer et al., 1988; Nederlof et al., 1989).

Aneuploidy studies of human spermatozoa were first performed by using differential staining techniques (Geraedts and Pearson, 1974) followed by penetration studies of zona-free hamster oocytes (Rudak et al., 1978) and autoradiographic in situ hybridization (Joseph et al., 1984). Studies of human oocytes and zygotes became possible with the introduction and development of in vitro fertilization (IVF) treatment. These cell types, however, have hardly been studied by nonradioactive in situ hybridization techniques.

This report presents the results of a nonisotopic hybridization method on human oocytes, spermatozoa, and abnormally fertilized or developed zygotes. 


\section{Cells}

Human spermatozoa from healthy donors were washed several times, resulting in a small sperm pellet which was fixed in three changes of methanol : acetic acid (3:1). Sperm cell suspensions were dropped onto clean dry slides after which the preparations were air-dried.

Unfertilized human oocytes and cleavage arrested preembryos (IVF failures) were prepared using a modification of Tarkowski's air-drying technique (Pieters et al., 1989).

Multipronuclear zygotes were incubated for $24 \mathrm{~h}$ in $1 \mathrm{ml}$ culture medium (Whittingham's T6 medium supplemented with $15 \%$ patient serum) with Colcemid to arrest cleavage at metaphase. The preparation and fixation technique was the same as for the human oocytes.

Labeling of DNA probes and visualization of the specific hybrids

The Chemiprobe kit (FMC BioProducts, Amstelstad bv., Zwanenburg) is a system for nonradioactive labeling of DNA probes. The labeling is based on a transamination reaction, resulting in a sulfone group on the cytosine moieties. Labeling was performed according to the manufacturer's instructions. Following their hybridization onto target DNA sequences, these probes can be visualized immunocytochemically using fluorochromes as reporter molecules. The sulfonated DNA probe was purified by desalting on a small column (in a $1 \mathrm{ml}$ syringe) of Sephadex G75. Visualization of the hybridized DNA was carried out by binding a specific mouse monoclonal antibody to the labeled DNA hybrid, followed by a second immunocytochemical reaction with an immunoglobulin conjugate (anti-mouse IgG fluorescein isothiocyanate [FITC] conjugate, Sigma), which binds at the location of the primary immune reaction, giving a bright fluorescent spot. 


\section{Prehybridization treatment}

To remove the excess of acetic acid (from the fixatives) still present on the glass slides, the preparations were washed in $2 \times$ SSC and dehydrated through an ethanol (70-90-100\%) series followed by air-drying.

To make sperm nuclei accessible to the probes, slides were incubated in $50 \mathrm{mM}$ dithiothreitol (DTT) in $0,1 \mathrm{M}$ Tris-HCl buffer, pH 8,0 or $25 \mathrm{mM}$ DTT in $0.1 \%$ trypsin (Difco) at room temperature for $10-20 \mathrm{~min}$, washed twice in $2 \times \mathrm{SSC}$, and finally dehydrated through an ethanol series and air-dried (Jones et al., 1987).

Human oocytes and abnormally fertilized or developed zygotes were treated with RNase $(100 \mu \mathrm{g} / \mathrm{ml}$ in $2 \times$ SSC) under a coverslip for $1 \mathrm{~h}$ at $37^{\circ} \mathrm{C}$ in a moist chamber, washed in 2 changes of $2 \times \mathrm{SSC}$ at room temperature $10 \mathrm{~min}$ each, followed by dehydration in an ethanol series. After washing the slides once for $7.5 \mathrm{~min}$ in a buffer solution $(20 \mathrm{mM}$ Tris $-\mathrm{HCl}, 2 \mathrm{mM} \mathrm{CaCl}, \mathrm{pH} 7.4$ at $37^{\circ} \mathrm{C}$ ) they were treated with proteinase $\mathrm{K}(0.1 \mu \mathrm{g} / \mathrm{ml})$ in the same buffer for $7.5 \mathrm{~min}$ at $37^{\circ} \mathrm{C}$. After washing twice in PBS or Dulbecco A (Sigma), $50 \mathrm{mM} \mathrm{MgCl}_{2}$, slides were refixed for 10 min in the same buffer containing $4 \%$ formaldehyde. Finally, slides were washed in PBS and dehydrated in an ethanol series and air-dried (Hopman et al., 1986).

\section{DNA probes}

The DNA probe (pUC 1.77), specific for the centromeric region of chromosome 1 and showing some cross-hybridization with the centromeric region of chromosome 9 (Cremer et al., 1988), represents a $1.77-\mathrm{kb}$ cloned Eco RI fragment of human satellite III DNA (Cooke and Hindley, 1979) and was a generous gift of Howard Cooke. The Amprobe RPN $1305 \mathrm{X}$ (Amersham) was used as a human Y-chromosome-specific DNA probe. It recognizes a highly repetitive (2,000 times) sequence of $2.47 \mathrm{~kb}$ on the distal region of the long arm of the $\mathrm{Y}$-chromosome (Cooke et al., 1982). In the experiments, the full plasmid was used, but before labeling, the average fragment length was reduced to \pm 500 bp by sonication.

\section{Hybridization}

Denaturation of probe and target DNA on the slides was performed simultaneously. Five to ten microliters of labeled probe $(5-10 \mathrm{ng} / \mu \mathrm{l}$ in a hybridization mixture of $60 \%$ deionized formamide, $2 \times$ SSC) were applied to the slide, covered with a $18 \times 18 \mathrm{~mm}$ coverslip and incubated on a $80^{\circ} \mathrm{C}$ hot plate for $2-5$ min. The slides were then immediately transferred to a moist chamber for hybridization overnight at $37^{\circ} \mathrm{C}$.

Posthybridization steps were the same for all cell types. Following hybrid- 
ization, the slides were washed twice with $60 \%$ formamide, $2 \times$ SSC followed by two washes in $2 \times \mathrm{SSC}, 0.05 \%$ Tween $20,10 \mathrm{~min}$ each, at room temperature.

To prevent nonspecific immune reactions, blocking was performed with $5 \%$ normal human serum (NHS) in PBS $(75 \mu$ l under a coverslip for 45 min in a moist chamber at $37^{\circ} \mathrm{C}$ ). After blocking, slides were washed twice in $2 \times \mathrm{SSC}, 0.05 \%$ Tween 20 and once in PBS, $10 \mathrm{~min}$ each, at room temperature. Slides were incubated with $75 \mu \mathrm{l}$ of mouse monoclonal antiserum diluted 1:100 in PBS containing $5 \%$ NHS for $45 \mathrm{~min}$ in a moist chamber at $37^{\circ} \mathrm{C}$. Washing was performed as described above, twice in $2 \times$ SSC, $0.05 \%$ Tween 20 and once in PBS, 10 min each at room temperature. Subsequently $75 \mu \mathrm{ll}$ of goat anti-mouse IgG FITC conjugated in the same buffer (1:100 dilution) was put on the slides under a coverslip after which the preparations were incubated for 45 min in a moist chamber at $37^{\circ} \mathrm{C}$ ). Subsequent washing and ethanol dehydration were as described above.

Counterstaining of cells was performed with DAPI $(0.5 \mu \mathrm{g} / \mathrm{ml}$, Sigma). The slides were examined with a Leitz fluorescence microscope $(1,000 \mathrm{x})$. The FITC was excited at $450-490 \mathrm{~nm}$ and hybrids appeared as yellowgreen spots, while the rest of the cell or chromosomes appeared red.

\section{Results}

Slide preparations from ejaculated human spermatozoa showed variable results. Without pretreatment, the sperm heads remained morphologically unaltered after in situ hybridization and showed no fluorescent staining at all. To make sperm nuclei accessible for the in situ hybridization technique, swelling by DTT treatment proved to be necessary. Duration of DTT treatment seemed to be of importance since both morphologically unaltered (DTT treatment of less than $10 \mathrm{~min}$ ) and overtreated sperm heads (DTT treatment more than $20 \mathrm{~min}$ ) gave no analyzable results. Unaltered sperm heads showed no staining at all while the extremely swollen sperm heads were destroyed by the procedure and staining was observed everywhere on the morphologically indistinct patches of sperm head material. Only DTT treatment of $10-15$ min gave spermatozoa with good hybridization signals. The numbers of accessible sperm cells varied from less than $40 \%$ to over $60 \%$ and were not only different between donors but also between the slides from the same donor.

After performing in situ hybridization with the chromosome-1 specific DNA probe, bright fluorescent spots could be observed in all nuclei of accessible spermatozoa. Twenty-three out of $3,000(0.8 \%$, range $0.6-1.1 \%)$ screened sperm heads showed two spots of similar intensity, strongly suggesting disomy of these sperms.

Using the Y-specific probe, it was possible to distinguish two classes of sperm cells, with and without a fluorescent spot. It might be presumed 
that the method determines whether or not sperms are carrying a $Y$ chromosome, since out of 1,524 accessible sperm heads, 741 (48.6\%, range 48.1-49.1\%) showed a fluorescent spot (Fig. 1).

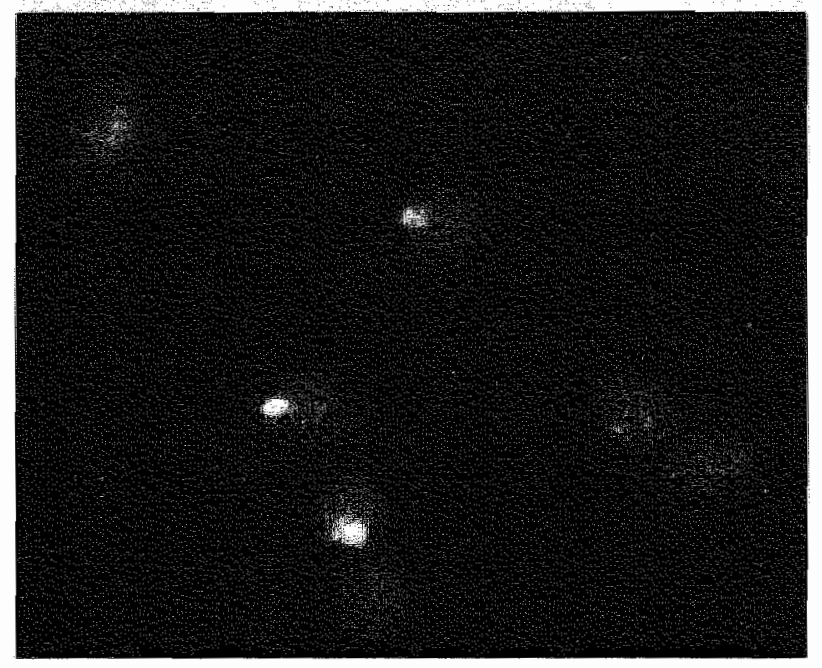

Figure 1. Human spermatozoa. Half the number of cells are positive after hybridization with a Yspecific DNA probe

Using the chromosome 1-specific probe on human oocytes, a hybridization signal was observed in seven out of twelve cases (Fig 2). The size and intensity of the staining of the hybrid was variable from a very bright fluorescent spot to a small one. From the seven oocytes with a positive hybridization signal, three showed a bright fluorescent spot while the remaining four showed a minor spot.

Four cytologic preparations of cleavage arrested human preembryos showed three (1 preembryo), four (2), and eight (1) highly spread interphase nuclei in phasecontrast micro-scopy. In situ hybridization on these slides was performed using the chromosome 1-specific probe. Two preembryos were lost from the preparation during the denaturation procedure. One of the preparations with four highly spread interphase nuclei showed two bright fluorescent spots and two weaker signals in two of the nuclei (Fig. 3). The preparation with eight interphase nuclei showed comparable results. These findings strongly suggested the presence of two copies of chromosome 1 and two minor binding sides which are known to be on chromosome 9.

Two zygotes showing three pronuclei and two zygotes with four pronuclei were studied in the same way. After hybridization with the chromosome 1 specific probe, a triploid embryo showed three spots proving that three copies of chromosome 1 were present. A preparation made from one human zygote with four pronuclei 20 hours after in vitro insemination showed four more or less haploid metaphase nuclei in phase contrast microscopy. Performing in situ hybridization with the $\mathrm{Y}$-specific probe, 
three out of four metaphases were found to be strongly positive (Fig. 4). In the remaining two preparations no hybridization signals were found.

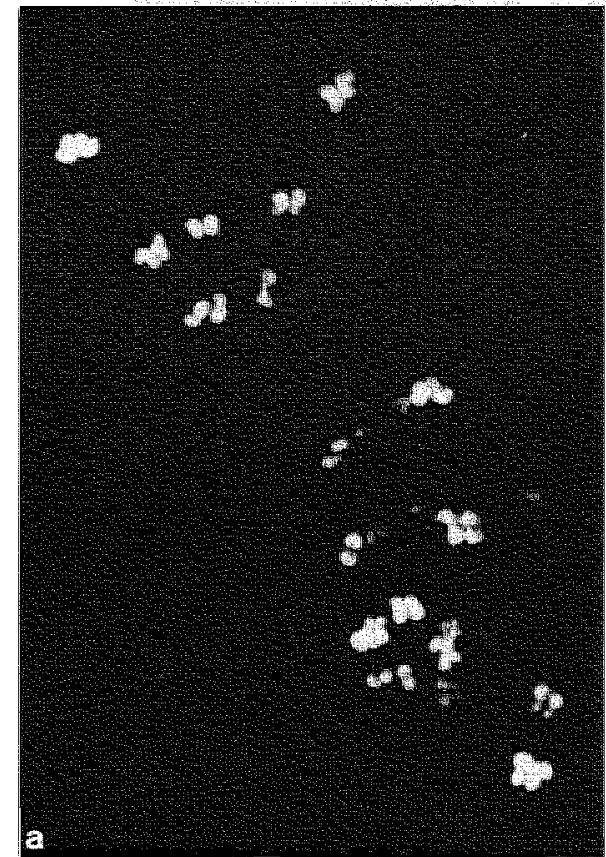

Figure 2. In situ hybridization of clone pUC 1.77 to human oocyte metaphase II chromosomes. Shown are DAPI counterstaining (a) and the same spread with one fluorescent (FITC) spot on the centromeric region of the largest meiotic chromosome (b).

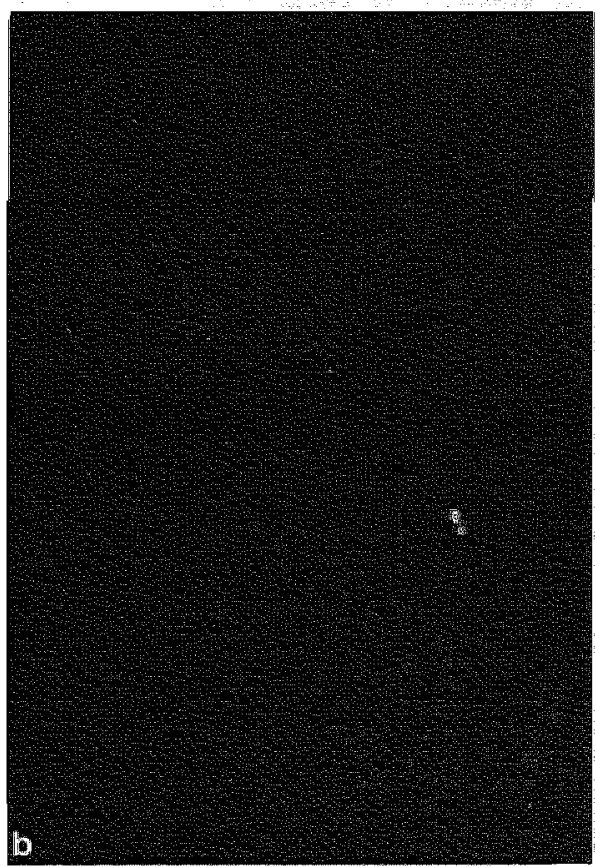



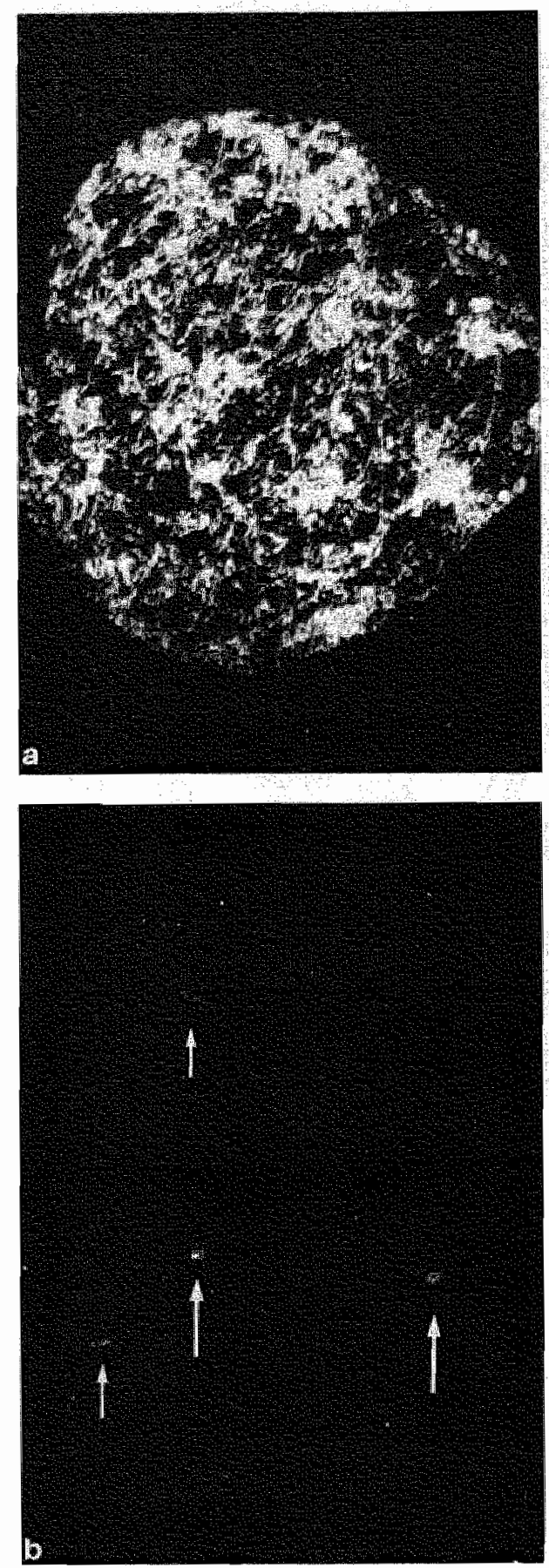

Figure 3. In situ hybridization of the chromosome 1-specific DNA probe to a highly spread interphase nucleus of a cleavage arrested preembryo. Shown are DAPI counterstaining (a) and the same nucleus with two bright fluorescent spots (large arrows) and two minor spots, probably derived from chromosome No 9 (small arrows) (b). 

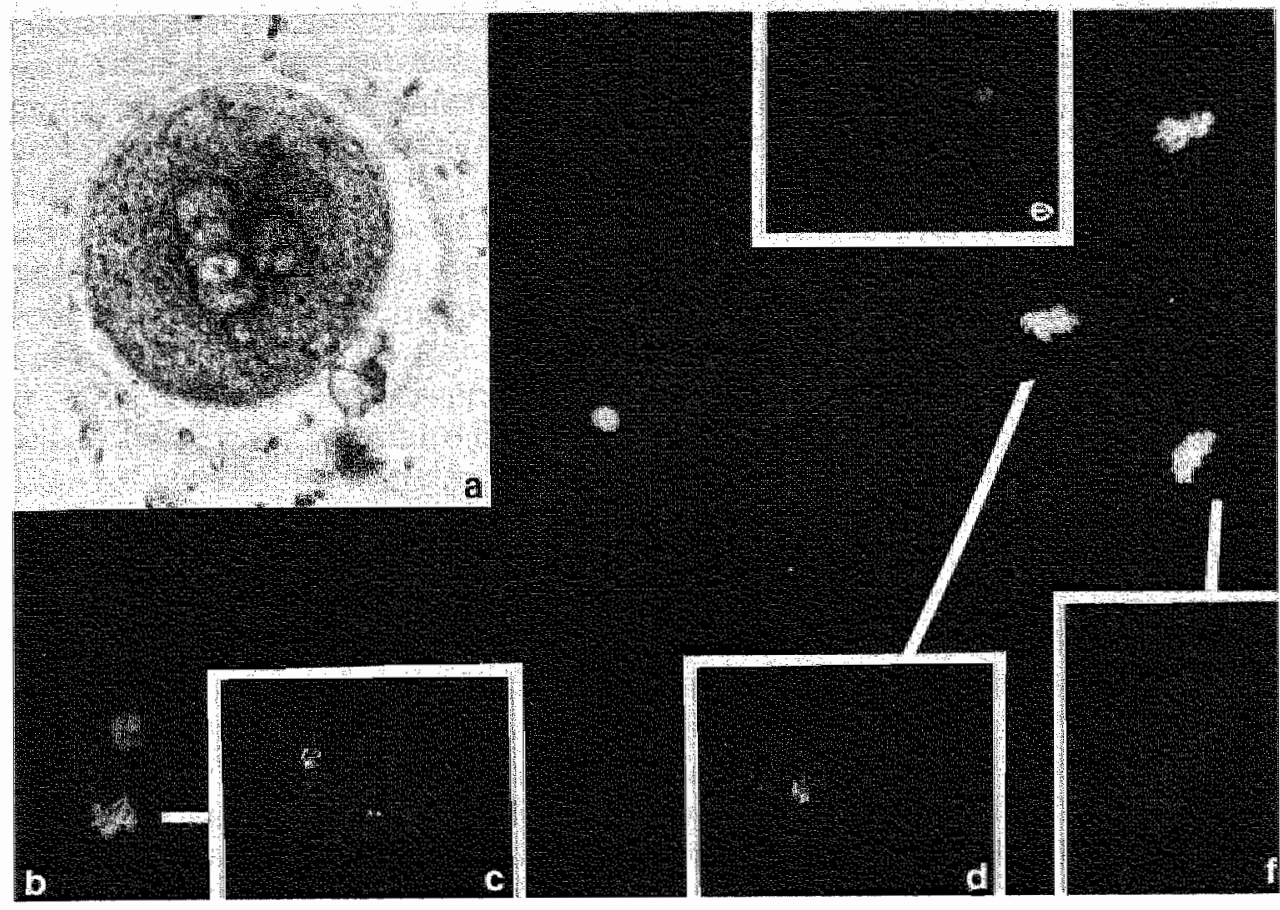

Figure 4. (a) Human zygote with four pronuclei 20 hours after in vitro fertilization (phase contrast). (b) Cytologic preparation of the same zygote showing four grossly haploid chromosome sets, overall picture with DAPI counterstaining. (c,d,e) In situ hybridization with the $\mathrm{Y}$-specific DNA probe resulting in a bright fluorescent spot in three metaphases and (I) a haploid chromosome set showing no positive hybridization.

\section{Discussion}

Nonisotopic methods for in situ hybridization can overcome the major disadvantages of autoradiographical detection since it is not necessary to use radioisotopes and the signal can be generated in a few hours. In situ hybridization techniques to study the chromosome content of human sperms have been applied in only very few studies (Joseph et al., 1984; Burns et al., 1985). Using an autoradiographic hybridization method with exposure times of 7-90 days, Joseph et al. (1984) could visualize hybridization of chromosome-specific probes in nuclei of human testicular sperms.

With Chemiprobe labeling and in situ hybridization procedure it was possible to obtain results within 24 hours. Positive results of hybridization, showing minimal background noise, were found in all cell 
types. After hybridization of probe to ejaculated human sperm cells, almost all accessible spermatozoa showed a fluorescent spot with the chromosome 1-specific DNA probe. Two chromosome 1-specific spots were found in $0.8 \%$, which is about twice the frequency observed by Joseph et al. (1984), who reported $0.35 \%$. It is unlikely that this presumed disomy for chromosome 1 is caused by cross-hybridization with chromosome 9 because the sizes of the spots were almost identical, whereas a chromosome 9 spot is much smaller. Furthermore, if chromosome 9 would be visible in sperm, double spots should with lower intensities should also be found. Hybridization with the Y-specific DNA probe showed a fluorescent spot in $48.6 \%$ of the human sperm cells. This result is comparable to those of other investigations (Geraedts and Pearson, 1974; Rudak et al,, 1978; Joseph et al., 1984). For the in situ hybridization on human spermatozoa it is clear that the accessibility of the sperm cells is one of the main problems. Sperm at different stages of maturation (as in ejaculated sperm) are differentially condensed (Bedford et $a l_{.}, 1972$ ) and thus may show varying levels of hybridization relative to the accessibility of the target DNA for hybridization. Only by the use of testicular sperm were Joseph et al. (1984) successful, while in our study analyzable results were obtained on ejaculated spermatozoa. Only very small aliquots of sperm suspensions are needed, which means that we now have a reliable method to control sperm selection techniques for the separation of $\mathrm{X}$ - and $\mathrm{Y}$-bearing spermatozoa.

The in situ hybridization technique using a chromosome 1-specific probe on female gametes was not easy to perform. Only about half the number of oocytes showed a bright fluorescent spot. The condensation grade of meiotic chromosomes is extremely high and it is probably for that reason that single stranded DNA is difficult to obtain and only a few hybrids can be formed, giving a much weaker signal. The findings of variable fluorescent spots (both in intensity and size) can also be explained by the distribution of constitutive heterochromatin in the population. Chromosome 1 polymorphisms show a wide variation in constitutive heterochromatin, to which probe pUC 1.77 hybridizes. The difficulty of in situ hybridization on meiotic chromosomes from oocytes might be reflected by the fact that no other reports are known to us, indicating similar difficulties being encountered by others.

To study the suitability for human preembryos, the described method was performed on abnormally developed (cleavage arrested, fragmented) preembryos. Finding two bright spots and two minor signals in extremely spread interphase nuclei of two different preembryos can be interpreted as follows. The chromosome 1-specific DNA probe is of the satellite III DNA type and additional copies of related sequences are located elsewhere in the genome but produce a much weaker signal (Cremer et al., 1988). In our study, not all nuclei showed fluorescent spots, and, from West et al. (1988) it is clear that a certain number (3-6) of nuclei are necessary to obtain reliable results. Early cleavage stages of preembryos 
have large nuclei with relatively diffuse DNA strands (West et all, 1988) and, since it is known that the denaturation of the in situ hybridization procedure leads to loss of DNA up to $40 \%$ (Raap et all, 1986), our preliminary results are encouraging. Denaturation is likely to be the most critical moment of the procedure since only the slides which were heat denaturated for three minutes at $80^{\circ} \mathrm{C}$ gave a positive result. The nuclei on the other two slides were denaturated for five minutes at the same temperature and thereby probably destroyed.

Three out of four grossly haploid metaphases from a multipronuclear zygote showed a fluorescent spot after hybridization with the Y-specific DNA probe which means that at least three of four nuclei were contributed by the father. At this moment it is not clear whether the remaining two multipronuclear zygotes were false negatives or were penetrated by $\mathrm{X}$-bearing sperms. False negative results (in oocytes or in zygotes) might result from a remaining zona pellucida (Jones et al., 1987).

With the described method, preimplantation sexing of cells from human preembryos is in theory possible. However, its utility after the recent introduction of a fast polymerase chain reaction method (Handyside et al., 1989) is in doubt. In situ hybridization techniques seem more useful to study the distribution of chromosomes in a large number of cells, i.e., to study the sex chromosomes in spermatozoa and the influence of separation methods.

\section{Acknowledgements}

The authors wish to thank Marijke Bras, Wiel Debie and Frank Kornips for their technical assistance and Francis van der Lubbe for her excellent photography. This investigation has been supported by the foundation for Medical and Health Research Medigon (grant no. 900-504-067).

\section{References}

Bedford JM, Cooper GW, Calvin HI: Post meiotic changes in the nucleus and membranes of mammalian spermatozoa, in Beatty RA, Gluecksohn-Waelsch $\mathrm{S}$ (eds): The genetics of the spermatozoan, pp 69-89. (Edinburgh, New York 1972)

Burns J, Chan VTW, Jonasson JA, Fleming KA, Taylor S, McGee JO'D: Sensitive system for visualising biotinylated DNA probes hybridised in situ: rapid sex determination of intact cells. J Clin Pathol 38:1085-1092 (1985)

Cooke HJ, Hindley J: Cloning of human satellite III DNA: different components are on different chromosomes. Nucl Acids Res 6:3177-3197 (1979) 
Cooke HJ, Schmidlke J, Gosden JR: Characterisation of a human $Y$ chromosome repeated sequence and related sequences in higher primates. Chromosoma 87:491$502(1982)$

Cremer T, Landegent J, Brückner A, Scholl HP, Schardin M, Hager HD, Devilee P, Pearson P, van der Ploeg $M_{\text {* }}$. Detection of chromosome aberrations in the human interphase nucleus by visualization of specific target DNAs with radioactive and non-radioactive in situ hybridization techniques: diagnosis of trisomy 18 with probe Li.84. Hum Genet 74:346-352 (1986)

Cremer T, Tesin D, Hopman AHN, Manuelidis L: Rapid interphase and metaphase assessment of specific chromosomal changes in neuroectodermall tumor cells by in situ hybridization with chemically modified DNA probes. Exp Cell Res 176:199-220 (1988)

Gall JG, Pardue ML: Formation and detection of RNA-DNA hybrid molecules in cytological preparations. Proc Natl Acad Sci USA 63:378-383 (1969)

Geraedts JPM, Pearson PL: Chromosomes in human spermatozoa, in Pearson PL, Lewis KR (eds): Chromosomes Today, proceedings of the Leiden chromosome conference, pp 23-32 (John Wiley and Sons, New York 1974)

Handyside AH, Penketh RJA, Winston RML, Pattinson JK, Delhanty JDA, Tuddenham EGD: Biopsy of human preimplantation embryos and sexing by DNA amplification. Lancet i:347-349 (1989)

Hopman AHN, Wiegant J, Raap AK, Landegent JE, van der Ploeg M, van Duijn P: Bi-color detection of two target DNAs by non-radioactive in situ hybridization. Histochemistry 85:1-4 (1986)

John H, Birnstiel ML, Jones KW: RNA-DNA hybrids at the cytological level. Nature (Lond.) 223:578-582 (1969)

Jones KW, Singh L, Edwards RG: The use of probes for the $Y$ chromosome in pre-implantation embryo cells. Hum Reprod 2:439-445 (1987)

Joseph AM, Gosden JR, Chandley AC: Estimation of aneuploidy levels in human spermatozoa using chromosome specific probes and in situ hybridisation. Hum Genet 66:234-238 (1984)

Langer PR, Waldrop AA, Ward DC: Enzymatic synthesis of biotin-labeled polynucleotides: novel nucleic acid affinity probes. Proc Natl Acad Sci USA 78:6633$6637(1981)$

Manuelidis L, Langer-Safer PR, Ward DC: High-resolution mapping of satellite DNA using biotin-labeled DNA probes. J Cell Biol 95:619-625 (1982)

Nederlof PM, van der Flier S, Raap AK, Tanke HJ, van der PLoeg M, Kornips F, Geraedts JPM: Detection of chromosome aberrations in interphase tumor nuclei by non-radioactive in situ hybridization. Cancer Genet Cytogenet 42:87-98 (1989) 
Pieters MHEC, Geraedts JPM, Dumoulin JCM, Evers JLH, Bras M, Kornips FHAC, Menheere PPCA: Cytogenetic analysis of in vitro fertilization (IVF) failures. Hum Genet 81:367-370 (1989)

Raap AK, Marijnen JGJ, Vrolijk J, van der Ploeg M: Denaturation, renaturation, and loss of DNA during in situ hybridization procedures. Cytometry 7:235-242 (1986)

Rudak E, Jacobs PA, Yanagimachi R: Direct analysis of the chromosome constitution of human spermatozoa. Nature 274:911-913 (1978)

West JD, Gosden JR, Angell RR, West KM, Glasier AF, Thatcher SS, Baird DT: Sexing whole human pre-embryos by in situ hybridization with a $\mathrm{Y}$-chromosome specific DNA probe. Hum Reprod 3:1010-1019 (1988) 


\section{Nonisotopic in situ hybridization as a method for nondisjunction studies in human spermatozoa}

E. Coonen, ${ }^{1}$ M.H.E.C. Pieters, ${ }^{1}$ J.C.M. Dumoulin, ${ }^{2}$ H. Meyer, J.L.H. Evers, ${ }^{2}$ F.C.S. Ramaekers, ${ }^{1}$ J.P.M. Geraedts ${ }^{1}$

1. Department of Genetics/Molecular Cell Biology, University of Limburg,

2. Department of Obstetrics/Gynaecology, Academic Hospital Maastricht, The Netherlands.

Molecular Reproduction and Development 28, 18-22, 1991. 


\section{Abstract}

Human spermatozoa were studied with a nonradioactive in situ hybridization method. Using a chemically modified DNA probe and immunocytochemical reactions for visualization, it was possible to obtain hybridization signals in 31 of 32 semen samples. Positive hybridization reactions, depending on cell accessibility, varied from $40 \%$ to over $90 \%$ for the different samples. Using a chromosome 1-specific DNA probe, disomy for this chromosome was found in $0.67 \%$ of all accessible sperm cells.

\section{Introduction}

Since its first introduction in 1969 (Gall and Pardue, 1969; John et al., 1969), the in situ hybridization (ISH) technique has been used to localize specific (i.e., target) DNA sequences in interphase and metaphase nuclei from many different cell types. Because of the poor microscopic resolution and the long exposure time needed, radiolabeled probes were replaced by biotinylated probes (Langer et al., 1981) and autoradiography by fluorescence visualization of the formed (DNA-DNA) hybrids (Manuelidis et al, 1982). Aneuploidy studies of human spermatozoa have been performed in different ways, but only few ISH results have been described. Negative ISH (Joseph et al., 1984) might have resulted from nonaccessibility of the spermatozoa, which is influenced by nucleus condensation and disulphide links between nucleoprotein chains in nuclear chromatin (Bedford et al., 1972). From both studies mentioned above, treatment with dithiotreitol (DTT) proved to be necessary. Successful attempts of ISH on ejaculated spermatozoa were reported by Burns et al. (1985) and Jones et al. (1987), who studied in situ hybridization with $\mathrm{Y}$ chromosome-specific probes in somatic cells and preimplantation embryonic cells, respectively.

The present paper summarizes the results of a nonisotopic ISH method that was carried out on semen samples from a series of normal partners of in vitro fertilization (IVF) patients. Although there is considerable heterogeneity between and within semen samples the method used gives reproducible nonradioactive ISH results (Pieters et al., 1990). 


\section{Materials and methods}

Material used for this study was obtained from a series of 32 normal healthy men who participated in an IVF program for nonmale indications. Spermatozoa were washed three times (in PBS), and the remaining sperm pellet was fixed in a small volume of methanol:glacial acetic acid (3:1). Sperm cells were diluted until the concentration was approximately 150 cells per microscopic field of view (magnification $\mathrm{x}$ 400). Following final dilution in fixative the sperm cell suspension was dropped onto clean dry slides and air dried.

Labeling of DNA probes and visualization of the specific hybrids.

Labeling of DNA probes was performed with the Chemiprobe kit (FMC BioProducts, Amstelstad bv. Zwanenburg). This procedure is based on a transamination reaction resulting in a sulfone group on the cytosine moieties (Budowsky et al., 1972). To visualize the labeled (DNA-DNA) hybrids, a specific mouse monoclonal antiserum was used. This was followed by a second immunocytochemical reaction with an immunoglobulin conjugate (antimouse IgG fluorescein isothyocyanate, Sigma) giving a bright fluorescent spot at the site of the primary immune reaction.

\section{Prehybridization treatment.}

Slides were washed in $2 \times$ SSC to remove the remainders of fixative and dehydrated through an ethanol series (70\%-90\%-100\%) and air dried. To make sperm nuclei accessible to the probes slides were incubated for 5-20 min in $25 \mathrm{mM}$ DTT in $0.1 \%$ trypsin (Difco). After incubation with DTT, slides were washed twice in $2 \times$ SSC and again dehydrated through an ethanol series and air dried (Jones et al., 1987).

\section{Hybridization}

For the experiments described in this paper, the DNA probe pUC 1.77, specific for the centromeric region of chromosome 1, was used. The probe represents a $1.77 \mathrm{~kb}$ cloned $E$ co RI fragment of human satellite III DNA (Cooke and Hindley, 1979) and was a generous gift of Howard Cooke.

Before denaturation $5 \mu \mathrm{l}$ of labeled probe $(5 \mathrm{ng} / \mu \mathrm{l}$ in a hybridization mixture of $60 \%$ formamide in $2 \times$ SSC) was applied to the slide and covered with a $18 \times 18 \mathrm{~mm}$ coverslip. Probe and target DNA on the slides were denatured simultaneously for $5 \mathrm{~min}$ on a $80^{\circ} \mathrm{C}$ hot plate, after 
which the slides were transferred immediately to a $37^{\circ} \mathrm{C}$ moist chamber for overnight hybridization.

\section{Posthybridization treatment.}

Posthybridization treatment and visualization of the target DNAs was performed as described previously (Pieters et al., 1990). Counterstaining of cells was performed with propidium iodide $(\mathrm{PI} ; 1 \mu \mathrm{g} / \mathrm{ml})$.

\section{Microscopic examination.}

The slides were examined with a Leitz fluorescence microscope (magnification $x$ 1,000). Positive hybridization signals appeared as yellow-green spots, whereas the rest of the spermatozoa appeared red. To establish the percentage of positive cells 1,000 sperms were scored after at random selection. To obtain information on disomic and diploid cells, 1,000 positive sperm were screened for the presence of more than one hybridization spot. Sperm heads showing clear size differences were assumed to be diploid.

\section{Results}

Slide preparations from ejaculated human spermatozoa of 32 healthy men with normal semen parameters (Table 1) were investigated.

Table 1. Semen parameters of 32 investigated men

Parameter

Volume $(\mathrm{ml})$

Conc. $\left(\times 10^{6} / \mathrm{ml}\right)$

Percent motile

MNSD $^{a}$
Mean

4.1

114

45

38.7
Range

$0.8-9.5$

20-300

30-75

7.2-145.6

${ }^{a}$ MNSD, motile normal sperm density (Glazener et al., 1987) 
Duration of DTT treatment appeared to be an important factor for successful in situ hybridization and had to be determined for each individual. On every semen sample a time series $(5-10-15 \mathrm{~min}$ ) was performed, and, on the basis of the visible result (Fig. 1), the best DTT time was chosen. Optimization of the treatment duration was obtained by a second time series starting with the DTT time from the first series plus or minus 1,2, and $3 \mathrm{~min}$. Results are summarized in Figure 2. Omission of pretreatment left the spermheads morphologically unaltered, and no
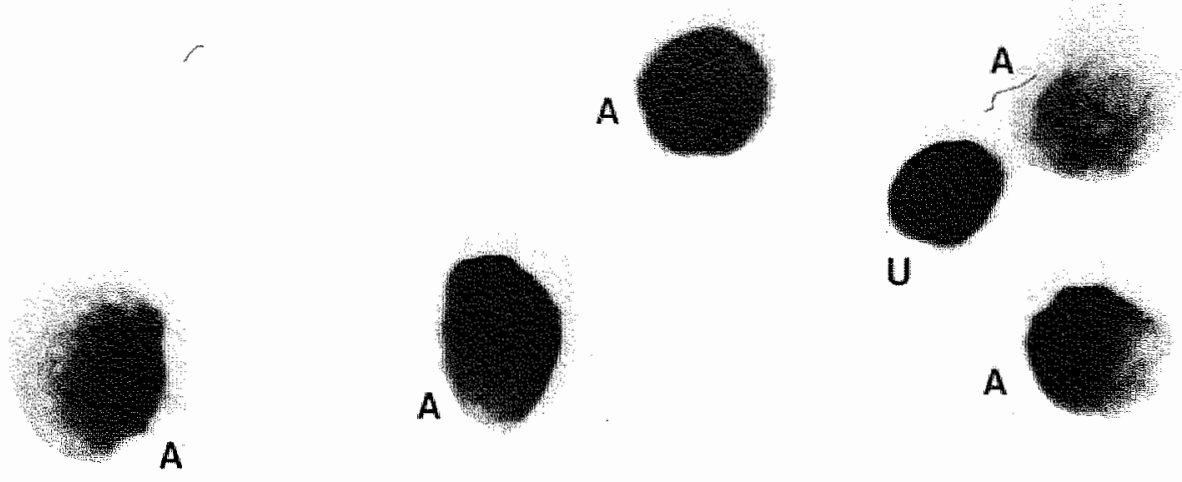

A

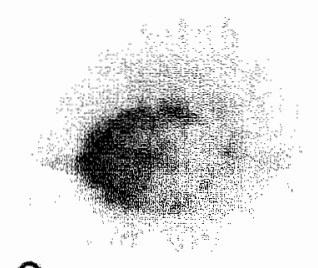

0

Figure 1. Morphology of human spermatozoa after DTT treatment. A, accessible; $\mathbf{U}$, undertreatment; $\mathbf{O}$, overtreatment.

fluorescent signal (as a reflection of a successful ISH) could be observed. Overtreatment with DTT caused lysis of spermatozoa, and after ISH only fluorescent grains could be observed, which were scattered all over the morphologically indistinct sperm heads. Therefore, the optimal DTT time was a compromise between the number of unaltered cells (undertreatment) and the number of destroyed spermatozoa (overtreatment). Only DTT treatment between 6 and 19 min gave analyzable results (Fig. 3A). One of the 32 cases investigated showed no positive signs of hybridization (Table 2). The percentages of spermatozoa with fluorescent spots calculated on the basis of the total number of analyzable spermatozoa varied from $40 \%$ to $90 \%$ for the different semen samples. 


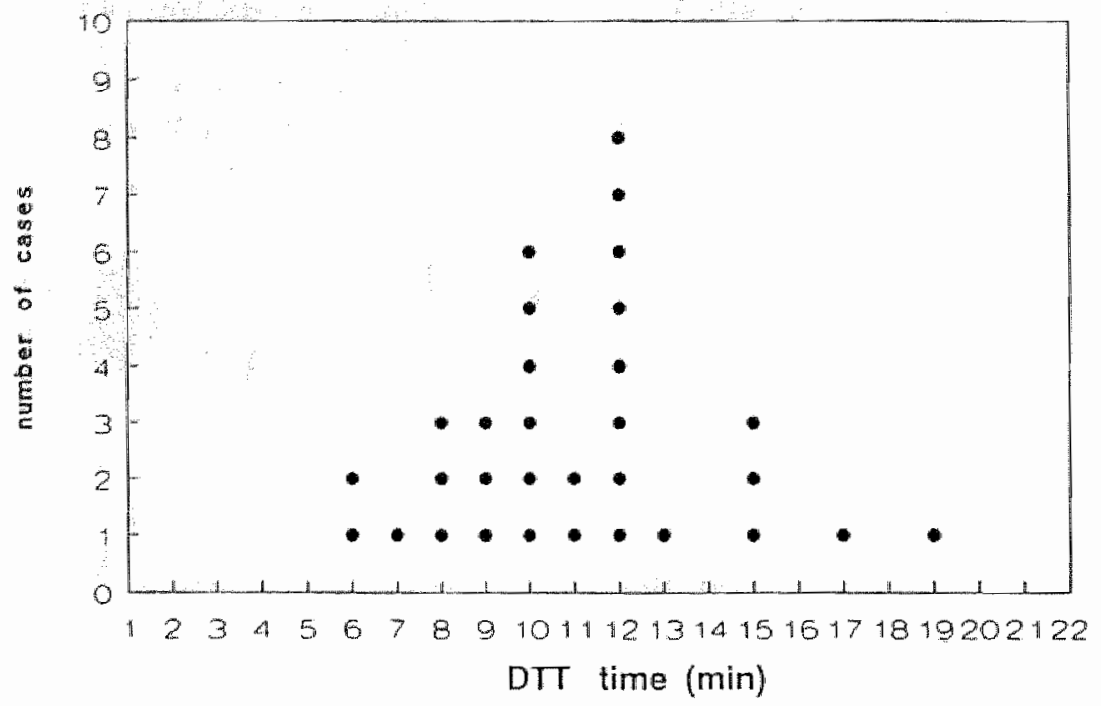

Figure 2. Distribution of DTT time among cases $(\bullet)$.

The real percentages of positively stained spermatozoa in relation to the total number of accessible spermatozoa are underestimated because spermatozoa that were morphologically unaltered or destroyed were regarded as negatively stained. More than one in situ hybridization signal of roughly equal size and intensity was interpreted as resulting from nondisjunction. A mean of $0.67 \%$ (range $0.2-1.3 \%$ ) of all successfully hybridized spermatozoa showed two fluorescent spots, whereas the volume of the sperm head appeared normal, indicating disomy for chromosome 1 (Fig. 3B). No spermatozoa with more than two spots were found. A mean of $0.33 \%$ (range $0.0-0.6 \%$ ) of all spermatozoa counted showed two fluorescent spots, and the volume of the spermhead was clearly increased, probably indicating diploid sperm cells (Fig. 3C).

To detect intraindividual differences, the homogeneity of the results was evaluated with the $x^{2}$ method. For the percentages of positive cells and disomy and diploidy cells, the respective means were used as expectations. The summated $x^{2}$ values were $39.0,3.3$, and 2.4 respectively $(\mathrm{df}=30$ ). This means that the data can be regarded as homogeneous. 

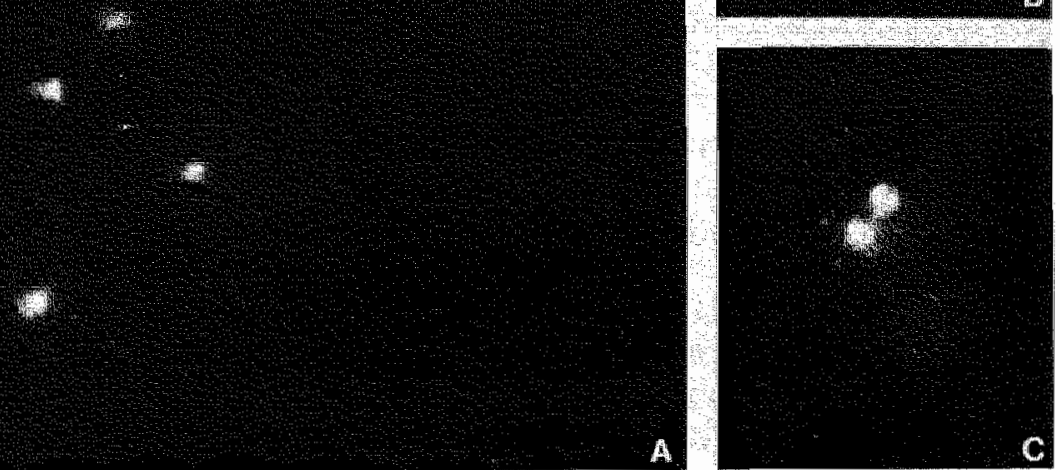

Figure 3. Human spermatozoa after in situ hybridization with pUC 1.77. A: One fluorescent spot in every sperm cell. B: Two spots in a normal sperm, indicating disomy. C: Two spots in a large sperm cell, indicating diploidy. 
Table 2. ISH scores of 32 men investigated

Percentage of

Subject
Aneuploidy(\%)

\section{Disomy Diploidy}

\begin{tabular}{llll}
01 & 63 & 1.0 & 0.3 \\
02 & 63 & 0.6 & 0.3 \\
03 & 61 & 0.9 & 0.3 \\
04 & 59 & 0.9 & 0.2 \\
05 & 76 & 0.6 & 0.3 \\
06 & 89 & 0.9 & 0.3 \\
07 & 64 & 0.8 & 0.3 \\
08 & 71 & 0.6 & 0.6 \\
09 & 65 & 0.4 & 0.2 \\
10 & 59 & 0.5 & 0.2 \\
11 & 64 & 0.4 & 0.6 \\
12 & 39 & 0.9 & 0.3 \\
13 & & & \\
14 & & 0.2 & 0.2 \\
15 & 64 & 0.6 & 0.2 \\
16 & 73 & 0.3 & 0.3 \\
17 & 60 & 0.8 & 0.5 \\
18 & 57 & 0.3 & 0.6 \\
19 & 62 & 0.6 & 0.6 \\
20 & 64 & 0.8 & 0.4 \\
21 & 80 & 0.8 & 0.0 \\
22 & 70 & 1.3 & 0.0 \\
23 & 65 & 0.2 & 0.5 \\
24 & 62 & 1.2 & 0.3 \\
25 & 76 & 0.8 & 0.3 \\
26 & 57 & 0.5 & 0.5 \\
27 & 60 & 0.6 & 0.2 \\
28 & 70 & 0.5 & 0.3 \\
29 & 55 & 0.9 & 0.3 \\
30 & 67 & 0.9 & 0.6 \\
31 & 56 & 0.5 & 0.3 \\
32 & 52 & 0.6 & 0.3 \\
Average & 64 & 0.67 & 0.33 \\
& 64 & & \\
\hline
\end{tabular}

${ }^{a}$ No ISH could be achieved. 


\section{Discussion}

The total procedure takes only about $24 \mathrm{hr}$ whereas an autoradiographical method can take between 1 week and 3 months (Joseph et al., 1984). Therefore, the nonisotopic ISH method presented here provides a reasonable alternative to overcome one of the major disadvantages of autoradiographical detection. Furthermore, it is of great advantage that the use of radioisotopes is prevented. Only recently was it possible to perform ISH on ejaculated spermatozoa (Guttenbach and Schmid, 1990). Previous attempts were unsuccessful, probably because of the difficulty of making the sperm cells accessible for the DNA probes without destroying them completely. Bedford et al. (1972) stated that, while in the epididymis, human spermatozoa undergo chemical changes in the nucleus and surface membrane. The stabilization of the nuclear chromatin by establishment of $-\mathrm{S}-\mathrm{S}$ - crosslinks between the nucleoprotein chains influences the accessibility. By treating the spermatozoa with DTT, the covalent disulphide links in the nuclear chromatin are reduced, providing a way for the DNA probes to contact the target DNA. Using the chromosome 1 -specific probe, fluorescent signals could be generated in $40-90 \%$ of the counted spermatozoa. The variation in relative frequency of positively stained spermatozoa can be explained by the fact that sperm nuclei in the human ejaculate are at different stages of maturation and stability, which is reflected in a variable accessibility of the cells to the DNA probes. In cases of a low percentage of positively stained sperm cells, increasing the DTT treatment time did not result in a higher percentage of accessible sperm cells. The optimal time appeared to be variable, probably due to the biological heterogeneity of the ejaculated sperm samples. We have no explanation for the one case that remained negative. False negative results might be caused by an undertreatment (less than $6 \mathrm{~min}$.) or an overtreatment (more than $19 \mathrm{~min}$.) of the spermatozoa with DTT prior to hybridization. Under- or overtreatment in the negative case is unlikely since the sperm cells showed the same morphological features as those on the preparations with positive results. The proportion of nullisomic spermatozoa cannot be established directly, since the majority of cells will show no hybridization for methodological reasons. However, it might be assumed that there is an equal proportion of nullisomic and disomic sperms. No relation could be found between the individual optimal DTT treatment time and the semen parameters summarized in Table 1. Blocking aspecific immune reactions proved to be important in preventing false-positive results. Since it is possible to discriminate between spermatozoa with one or two (and more) spots, an indication is given of the percentage of aneuploidy in a semen sample. Two chromosome 1-specific spots (disomy) were observed in $0.67 \%$ of the sperm cells, which is about twice as high as was reported by Joseph et al. (1984) for chromosome $1(0.35 \%)$ and Guttenbach and Schmid (1990) for the Y-chromosome $(0.27 \%)$. The mean percentage of diploid sperm 
cells was $0.33 \%$. This was based on the assumption that it is possible to establish the ploidy level from the head size, as indicated by Joseph et al. (1984). Individual aneuploidy levels did not differ significantly from the mean. The aneuploidy findings in this study are slightly higher than most results reported in other studies. Although false-positive results, due to artefact staining, can not be excluded, an explanation could be the unselected sperm cell analysis.

Different investigations of human spermatozoa have revealed aneuploidy for chromosome 1 from $2 \%$ with less specific staining of heterochromatin (Geraedts and Pearson, 1973) to less than 0.1\% in sperm penetrated zona-free hamster oocytes (Brandriff et al., 1986; Martin and Rademaker, 1990). Chromosome 1 disomic sperm are capable of oocyte penetration in vitro (Watt et al., 1987). It remains to be determined whether all aneuploid sperm cells are able to fertilize in vitro as well as in vivo.

\section{Acknowledgements}

The authors wish to thank Marijke Bras, Roselie Jongbloed and Wiel Debie for their technical assistance and Francis van der Lubbe for her excellent photography. This investigation has been supported by the foundation for Medical and Health Research Medigon (grant no. 900.504.067)

\section{References}

Bedford JM, Cooper GW, Calvin HI (1972): Post meiotic changes in the nucleus and membranes of mammalian spermatozoa, in Beatty RA, Gluecksohn-Waelsch S (eds): The genetics of the spermatozoan, pp 69-89. (Edinburgh, New York).

Brandriff B, Gordon L, Ashworth LK, Watchmaker G, Carrano AV (1986): Detection of chromosomal abnormalities in human sperm. In Ramel C, Lambert B, Magnisson $\mathfrak{J}$ (eds): "Genetic Toxicology of Environmental Chemicals. Part B: Genetic Effects and Applied Mutagenesis." New York: Alan R. Liss, Inc.. p 469.

Budowsky EI, Sverdlov ED, Monastyrskaya GS (1972): New method of selective and rapid modification of the cytidine residues. FEBS letters 25:201-204.

Burns J, Chan VTW, Jonasson JA, Fleming KA, Taylor S, McGee JO'D (1985): Sensitive system for visualising biotinylated DNA probes hybridised in situ: rapid sex determination of intact cells. J Clin Pathol 38:1085-1092.

Cooke HJ, Hindley J (1979): Cloning of human satellite III DNA: different components are on different chromosomes. Nucl Acids Res, 6:3177-3197.

Gall JG, Pardue ML (1969): Formation and detection of RNA-DNA hybrid molecules in cytological preparations. Proc Natl Acad Sci USA 63:378-383. 
Geraedts JPM, Pearson PL (1973): Specific staining of the human chromosome No. 1 chromosome in spermalozoa. Humangenetik 20:171-173.

Glazener CMA, Kelly NJ, Jane M, Weir A, David JSE, Cornes JS, Hull MGR (1987): The diagnosis of male infertility - prospective time-specific study of conception rates related to seminal analysis and post-coital sperm - mucus penetration and survival in otherwise unexplained infertility. Hum Reprod $2: 665$ 671.

Guttenbach M, Schmid M (1990): Determination of $\mathrm{Y}$ chromosome aneuploidy in human sperm nuclei by nonradioactive in situ hybridization. Am J Hum Genet 46:553-558.

John H, Birnstiel ML, Jones KW (1969): RNA-DNA hybrids at the cytological level. Nature (Lond.) 223:578-582.

Jones KW, Singh L, Edwards RG (1987): The use of probes for the $\mathrm{Y}$ chromosome in pre-implantation embryo cells. Hum Reprod 2:439-445.

Joseph AM, Gosden JR, Chandley AC (1984): Estimation of aneuploidy levels in human spermatozoa using chromosome specific probes and in situ hybridisation. Hum Genet 66:234-238.

Langer PR, Waldrop AA, Ward DC (1981): Enzymatic synthesis of biotin-labeled polynucleotides: novel nucleic acid affinity probes. Proc Natl Acad Sci USA 78:6633-6637.

Manuelidis L, Langer-Safer PR, Ward DC (1982): High-resolution mapping of satellite DNA using biotin-labelled DNA probes. J Cell Biol 95:619-625.

Martin RH, Rademaker A (1990): The frequency of aneuploidy among individual chromosomes in 6821 human sperm chromosome complements. Cytogenet Cell Genet 53:103-107.

Pieters MHEC, Geraedts JPM, Meyer H, Dumoulin JCM, Evers JLH, Jongbloed RJE, Nederlof PM, wan der Flier $\mathbf{S}$ (1990): Human gametes and zygotes studied by non-radioactive in situ hybridization. Cytogenet Cell Genet 53:15-19.

Watt JL, Templeton AA, Messinis I, Bell L, Cunningham P, Ducan RO (1987):

Trisony 1 in an eight ell human pre-embryo. J Med Genet 24:60-64. 



\section{Immaturity and aneuploidy in human oocytes after different stimulation protocols}

M.H.E.C. Pieters, ${ }^{1}$ J.C.M. Dumoulin, ${ }^{2}$ C.M. Engelhart, ${ }^{2}$ M. Bras, J.L.H. Evers, ${ }^{2}$ J.P.M. Geraedts ${ }^{1}$

1. Department of Genetics and Cell Biology, University of Limburg, Maastricht

2. Department of Obstetrics and Gynaecology, Academic Hospital Maastricht, The Netherlands.

Fertility \& Sterility 56, 306-310, 1991. 


\section{Abstract}

Objective: To study immaturity and aneuploidy in human oocytes after two different stimulation protocols.

Design: Retrospective.

Setting: Outpatient IVF clinic/laboratory.

Patients: One hundred forty-three patients of whom 65 were stimulated with clomiphene citrate (CC)/ human menopausal gonadotropin (hMG) and 78 were stimulated with gonadotropin-releasing hormone agonist (GnRH-a)/hMG. Only patients with at least one oocyte unfertilized were included in this study.

Results: Stimulation with $\mathrm{GnRH}-\mathrm{a} / \mathrm{hMG}$, as compared to $\mathrm{CC} / \mathrm{hMG}$ stimulation, resulted in larger numbers of oocytes $(P<0.00001)$, a higher fertilization rate $(P<0.02)$, and oocyte retrieval at a later average cycle day $(\dot{P}<0.000005)$. Cytogenetic findings of immaturity were observed in $33.9 \%$ of unfertilized oocytes after CC/hMG stimulation, compared to only $17.8 \%$ after $\mathrm{GnRH}-\mathrm{a} / \mathrm{hMG}$ stimulation $(P<0.0005)$. Aneuploidy findings were the same for both groups.

Conclusion: In GnRH-a/hMG stimulation, oocytes approach the normal day of ovulation more closely. This may allow for better oocyte maturation and higher fertilization and pregnancy rates.

\section{Introduction}

Using morphologic characteristics of the cumulus-corona cell complex, it is possible to estimate oocyte maturity. Although not as reliable as the presence of a polar body (reflecting completion of the first meiotic division), this maturity score of oocytes gives a fair correlation with fertilization rate in vitro. From several studies, it is clear that fertilization and implantation rates are influenced by hormonal stimulation protocols used to induce multiple follicle maturation., With the introduction of cytogenetic analysis of in vitro fertilization (IVF) failures, it has become possible not only to observe chromosomal abnormalities in human oocytes but also to determine some of the causes of early developmental arrest responsible for preimplantation loss. Immaturity of the oocytes may be reflected by the presence of oocyte diploidy, which is assumed to be a representation of the failure of polar body extrusion, ${ }^{6}$ and/or prematurely condensed sperm chromosomes, indicating sperm penetration of oocytes with immature cytoplasm.? Therefore, we decided to investigate the possibility that these features are caused by the hormonal stimulation protocol. The influence of the two most widely used hormonal stimulation protocols on the cytogenetic maturity of unfertilized oocytes was compared. At the same, time the two stimulation 
protocols were compared with respect to the aneuploidy ratios of the oocytes.

\section{Materials and methods}

\section{Patients and protocols}

Of all couples undergoing IVF and embryo transfer (ET) for a variety of infertility problems (Table 1) between February 1988 and September 1990,143 couples with at least one oocyte unfertilized were included in this study. Clomiphene citrate (CC, Clomid; Gist-Brocades B.V Leiderdorp, The Netherlands), $50 \mathrm{mg} / \mathrm{d}$ orally, from day 3 through day 7 of the menstrual cycle (protocoll $I, n=65$ ), or the gonadotropin-releasing hormone agonist (GnRH-a) busereline acetate (Suprefact; Hoechst B.V., Amsterdam, The Netherlands), $400 \mu \mathrm{g}$ t.i.d. intranasally (protocol II, $\mathrm{n}=$ 78), were used, in combination with human menopausal gonadotropin (hMG, Humegon; Organon, Oss, The Netherlands), tailored to the individual patient's needs, to stimulate multiple follicular development. In group II GnRH-a was started on day 21 of the cycle preceding IVF. Human chorionic gonadotropin (hCG, Pregnyl; Organon) 10,000 U intramuscularly was given as soon as the dominant follicle was judged to be mature $(>16 \mathrm{~mm}$ in case of $\mathrm{CC} / \mathrm{hMG},>18 \mathrm{~mm}$ in case of GnRH$\mathrm{a} / \mathrm{hMG}$ ) to induce final follicle and oocyte maturation and ovulation. Follicle growth was monitored by ultrasound and by daily determinations of serum $17 B$-estradiol $\left(\mathrm{E}_{2}\right)$ levels. Premature luteinization was excluded by daily serum luteinizing hormone (LH) determinations. Ultrasoundguided oocyte-retrieval was performed 32 to 34 hours after hCG administration. As soon as the oocytes were obtained they were transported to the laboratory, as was an ejaculate of the partner, which was produced 2 to 3 hours after ovum pick-up. Whittingham's T6 medium $^{8}$ supplemented with $10 \%$ inactivated maternal serum was used during preincubation and insemination of the oocytes. All oocytes studied were judged mature by the morphological aspect of the oocyte-cumuluscorona complex. The oocytes were routinely preincubated for 5 hours, and about 50,000 motile spermatozoa were added to each oocyte in $1 \mathrm{~mL}$ of medium in a four-well Multidish (Nunc; Life Technics BV., Breda, The Netherlands). About 20 hours after insemination, the cumulus cells were removed mechanically, and the oocytes were examined for the presence of pronuclei and transferred to fresh medium. Culture was continued for another 20 to 24 hours. Oocytes showing two or more pronuclei were considered to be fertilized. Embryo transfer, with embryos resulting from zygotes with two pronuclei, was performed 40 to 44 hours after insemination. 
Table 1. Infertility factors in CC/hMG- and $\mathrm{GnRH}$-a/hMG-stimulated cycles

Cause of infertility

$\mathrm{CC} / \mathrm{hMG}$

GnRH-a/hMG

Tubal infertility

35

Unexplained infertility

Endometriosis

Male infertility

Immunologic infertility

Other indications

Total

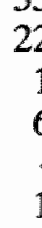

65
42

20

4

5

2

5

$78^{\mathrm{b}}$

ather indications: polycystic ovary syndrome, oocyte donation (donor), ovulation disorder.

${ }^{b}$ The distribution of infertility factors does not differ significantly between the two groups, i.e., neither the composition of the groups ( $P=$ $0.29)$ nor the proportion of male infertility $(P=0.75)$.

\section{Cytogenetic analysis}

Cytogenetic analysis was performed on oocytes that were considered to be unfertilized because of the absence of pronuclei 18 to 20 hours after insemination and that showed in addition no cleavage within 48 hours (IVF failures). Chromosome preparation of the oocytes was performed according to the method of Tarkowski ${ }^{9}$ with some modifications. ${ }^{10}$ The oocyte was placed in a hypotonic (1\%) sodium-citrate solution for about 15 minutes. Gradual fixation was done in three steps: first, a drop of \pm $100 \%$ methanol was placed on the oocyte, and rapidly after this, a drop of an acetic acid/methanol (vol:vol $=1: 5$ ) solution, and finally a drop of an acetic acid/methanol (vol:vol $=1: 3$ ) solution were added. The slide was dried, and preparations were stained in a $10 \%$ Giemsa solution. Oocyte chromosomes and sperm chromosomes were identified as described before.10 Chromosome numbers were determined by two independent investigators. Metaphase spreads leading to different opinions about the chromosome number or containing a chromosome number which could not be estimated accurately by both observers were scored on the basis of the ploidy. Oocytes were interpreted as immature if cytologic preparations showed an arrested metaphase I or when beside oocyte metaphase chromosomes (metaphase I or metaphase II) prematurely condensed sperm chromosomes were found. 
Statistics

Standard statistical analyses (Student's $t$-test and $x^{2}$ test) were done. A Pvalue $<0.05$ was accepted as indicating statistical significance.

\section{Results}

In this study, 143 couples undergoing IVF were included because they had at least one oocyte unfertilized. The numbers of oocytes retrieved, fertilized, and analyzed for both stimulation protocols are shown in Table 2. In CC/hMG-stimulated cycles, a mean of 6.8 oocytes were obtained (range 2 to 14) whereas in $\mathrm{GnRH}$-a/hMG-stimulated cycles a significantly higher $(P<0.00001)$ mean of 11.3 oocytes was retrieved (range 2 to 30 ). Oocyte maturity was scored on the basis of the degree of compactness of the cumulus-corona cell complex; no difference was found between the two study groups. For both stimulation protocols the day of oocyte retrieval was recorded. Because of the possibility of a spontaneous LH surge, CC/hMG-stimulated patients had been punctured earlier in their cycle (mean of cycle day $13.0 \pm 1.4$ ) than patients stimulated with GnRH-a/hMG (mean of day $14.2 \pm 1.6, P<0.000005$ ). The clinical pregnancy rates (PRs) for $\mathrm{CC} / \mathrm{hMG}$ and $\mathrm{GnRH}$-a/hMG stimulation were $18.5 \%$ and $25.6 \%$, respectively.

\section{Fertilization-penetration rates}

Fertilization rates for the $\mathrm{CC} / \mathrm{hMG}$ and $\mathrm{GnRH}-\mathrm{a} / \mathrm{hMG}$ groups were $53.4 \%$ and $60.4 \%$, respectively. By adding the number of fertilized oocytes to the number of sperm-penetrated oocytes, estimates of total sperm penetration numbers were obtained. For $\mathrm{CC} / \mathrm{hMG}$ stimulation the actual sperm penetration rate was $[(237+51) \div 444]=64.9 \%$, whereas for GnRH-a/hMG stimulation the penetration rate was $[(533+43) \div 882]=$ $65.3 \%$. 
Table 2. Fertilization and aneuploidy findings for both stimulation protocols ${ }^{\mathrm{a}}$

CC/hMG

GnRH-a/hMG

No. of patients

Total no. of oocytes

Mean no. of oocytes per patient

Fertilized oocytes

Analyzed oocytes

Haploid ( $n=23$ chromosomes)

Hyperhaploid ( $\mathrm{n}>23$ chromosomes)

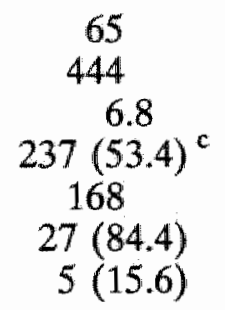

78

882

$11.3^{\mathrm{b}}$

$533(60.4)^{\mathrm{d}}$

264

$46(85.2)$

$8(14.8)$

a Only patients with at least one oocyte unfertilized were included.

b Mean number of oocytes retrieved was significantly higher in

GnRH-a /hMG-stimulated cycles $(P<0.00001)$.

Values in parentheses are percents.

Number of fertilized oocytes was significantly higher in

GnRH-a/hMG-stimulated cycles $(P<0.02)$.

Immaturity findings in relation to stimulation protocol

Features of sperm penetration and/or a metaphase I chromosome number in unfertilized human oocytes were assessed to estimate the frequency of oocyte immaturity obtained with the respective stimulation protocols (Table 3). For the CC/hMG protocol, 57 of 168 (33.9\%) analyzable preparations were found to be immature. For the GnRHa/hMG protocol, 47 of $264(17.8 \%)$ were immature $(P<0.0005)$.

Immaturity findings in relation to day of menstrual cycle

Cytogenetic findings in IVF failures on menstrual cycle day 12,13 , and 14 showed immaturity in $36.9 \%, 22.4 \%$, and $18.3 \%$ of the oocytes, respectively. Comparison of immaturity findings on day 12,13 , and 14 for both stimulation protocols revealed GnRH-a/hMG stimulation to yield lower immaturity percentages, although the difference reached the level of significance on day 14 only $(P<0.02)$. Actual preparation numbers and $P$-values are given in Table 4 . Because of insufficient numbers, immaturity findings before day 12 and after day 14 were not included in this table. 
Analyzable preparations

Metaphase I

Metaphase I + sperm chromosomes

Metaphase II + sperm ( 1 polar body)

Metaphase II + sperm ( 2 polar bodies)

Metaphase II

Other findings ${ }^{b}$

168

6

6

$31+57^{2}$

14

99

12
264

47

2

$32+47$

$9 \mathrm{~J}$

188

29

a Total of immaturity findings was significantly higher in CC/hMGstimulated cycles $(P<0.0005)$.

${ }^{b}$ Other cytogenetic findings: interphase nuclei, profasing chromosomes, mitotic chromosomes.

Table 4. Cytogenetic immaturity findings in IVF failures related to stimulation protocol and day of menstrual cycle

$\begin{array}{cccc}\mathrm{CC} / \mathrm{hMG} & \begin{array}{c}\text { GnRH-a/hMG } \\ \text { immaturity } / \text { total }\end{array} & P \text { - values } & \text { Total immaturity/ } \\ \text { immaturity } / \text { total }^{\mathrm{b}} & & \text { total }\end{array}$

Cycle day

$\begin{array}{rrrcr}12 & 22 / 54(40.7) & 9 / 30(30.0) & \mathrm{NS}^{\mathrm{c}} & 31 / 84(36.9) \\ 13 & 13 / 42(31.0) & 13 / 74(17.6) & \mathrm{NS} & 26 / 116(22.4)^{\mathrm{d}} \\ 14 & 14 / 47(29.8) & 7 / 68(10.3) & <0.02 & 21 / 115(18.3)^{\mathrm{e}} \\ & & & & \end{array}$

Total of immaturity findings.

b Total of cytogenetic preparations. Values in parentheses are percents.

NS, not significant.

'Immaturity findings were significantly more observed in oocytes retrieved on day 12 compared with day $13(P<0.05)$.

${ }^{\mathrm{C}}$ Immaturity findings were significantly more observed in oocytes retrieved on day 12 compared with day $14(P<0.01)$. 


\section{Aneuploidy}

To avoid confusion of oocyte chromosomes with decondensing sperm chromosomes, only oocytes showing no signs of sperm penetration were evaluated for their chromosome number. In this way the chromosome number of 86 oocytes was analyzable. Thirteen out of $86(15.1 \%)$ oocytes showed a hyperhaploid $(\mathrm{n}>23$ ) chromosome number. Presuming that each hyperhaploid cell has a hypohaploid counterpart, the calculated aneuploidy rate was $(13+13) \div 99=26.3 \%$. Comparison of aneuploidy rates between both stimulation protocols yielded no differences (Table 2). In CC/hMG stimulation, 5 of 32 (15.6\%) oocytes were hyperhaploid, giving a calculated aneuploidy ratio of $27 \%$, whereas in GnRH-a/hMGstimulated cycles 8 of $54(14.8 \%)$ oocytes were hyperhaploid, resulting in a calculated aneuploidy ratio of $25.8 \%$.

\section{Discussion}

Fertilization and implantation rates after embryo transfer are influenced by the preceding hormonal stimulation. In stimulation protocols used to induce multiple follicular development, the cohort of follicles ready to be recruited is expanded by adding follicles in early stages of development or by recruitment of follicles undergoing atresia." Because of abnormal cytoplasmic maturation, lower fertilization rates might be expected. ${ }^{12}$ The observation that in the present study the oocyte number and the fertilization rate were significantly higher in GnRH-a/hMG-stimulated cycles (Table 2) is in contrast with the previous finding that fertilization rate decreases as the number of oocytes retrieved increases. ${ }^{4}$ After assessment of actual sperm penetration rates, by summing fertilized and sperm penetrated oocytes, no difference was found between the stimulation protocols $(64.9 \%$ for $\mathrm{CC} / \mathrm{hMG}$ and $65.3 \%$ for $\mathrm{GnRH}-\mathrm{a} / \mathrm{hMG})$, indicating that sperm penetration was not different. Nevertheless, maturity of the oocytes can influence fertilization rates in human IVF programs. ${ }^{1.3}$ Oocyte maturity can be judged by the compactness of the cumulus-corona complex." The presence of a polar body, which is often difficult to determine under a light microscope, is probably the best assessment of oocyte maturity. ${ }^{2}$ Presence of a first polar body does not exclude cytoplasmic immaturity. Penetration of human oocytes arrested at metaphase II may occur without subsequent development of pronuclei. Cytoplasmic immaturity of the oocyte may impair the transformation of the sperm nucleus into a male pronucleus. Premature chromosome condensation in the sperm nucleus is induced instead. ${ }^{14}$ Cytoplasmic immaturity of the oocytes may be reflected in the presence of oocyte diploidy and/or prematurely condensed sperm chromosomes, ${ }^{5,6}$ Although all oocytes studied were judged mature by the morphological aspect of the oocyte-cumuluscorona complex, a significantly different $(P<0.0005)$ rate of oocyte 
cytoplasmic immaturity was found in CC/hMG-stimulated cycles (33.9\%) compared to GnRH-a/hMG-stimulated cycles (17.8\%) (Table 3). Because of the possibility of a spontaneous $\mathrm{LH}$ surge, oocytes were retrieved earlier in CC/hMG-stimulated cycles compared to GnRH-a/hMG stimulation, which might give an explanation for the higher ratio of immature oocytes in CC/hMG cycles. In GnRH-a/hMG-stimulated patients, oocyte retrieval and fertilization are performed closer to the day of ovulation in the spontaneous menstrual cycle ${ }^{15}$ (day 14), which may allow cytoplasmic maturity to reach its optimum. When maturity score was related to the day of the menstrual cycle, however, it became clear that it is not only the day of oocyte retrieval that is of importance in this respect. At days 12 and 13, immaturity rates were lower (although not significantly) in GnRH-a/hMG-stimulated cycles, and at day 14 the difference was even significant $(P<0.02)$. This indicates not only the stage of meiotic maturation to be of importance in stimulated cycles but cytoplasmic maturity as well.

Aneuploidy percentages can be calculated by taking into consideration all abnormal cells (i.e., hypohaploid and hyperhaploid chromosome numbers) and dividing their total number over the total number of cells scored. When this method is applied, it is not clear if the hypohaploid cellls are lacking one or more chromosomes as a result of nondisjunction, chromosome lagging during division, or preparation artifacts. Therefore, in our estimate of the aneuploidy percentage only the hyperhaploid cells were taken into consideration. It was assumed that hypohaploid cells arising from nondisjunction occured at an equal frequency. Data published about the frequency of chromosomal abnormalities in oocytes vary between $3 \%{ }^{16}$ and $65 \% .^{17}$ Aneuploidy findings in the present study are in between these two and are comparable with the findings from larger series as published by Pellestor and Sele ${ }^{18}$ and Plachot et al. ${ }^{19}$ who found $19 \%$ and $20 \%$, respectively. The use of two different hormonal stimulation protocols in the present study did not reveal different nondisjunction percentages. However, metaphase I chromosome sets (with or without sperm penetration) were found in $7.1 \%$ (12 of 168$)$ for $\mathrm{CC} / \mathrm{hMG}$ stimulation, as compared to only $2.3 \%$ (6 of 264) of the preparations of GnRH-a/hMG stimulation $(P<0.05$ ). When diploidy (reflecting nonpolar body extrusion) is seen as a sign of immaturity, this would be in line with the total immaturity findings in unfertilized oocytes.

We conclude that aneuploidy ratios are not influenced by hormonal stimulation. Maturity score, fertilization rate, and clinical PR are in favor of $\mathrm{GnRH}-\mathrm{a} / \mathrm{hMG}$ stimulation. This is probably caused by the fact that in the GnRH-a/hMG stimulation regimen oocytes are allowed to approach the normal day of ovulation, as seen in the spontaneous menstrual cycle, more closely. Indications for a negative influence of $\mathrm{GnRH}-\mathrm{a} / \mathrm{hMG}$ stimulation on follicle development were not found. 


\section{References}

1. Marrs RP, Salito H, Yee $\mathrm{B}_{\text {, Sato }} \mathrm{F}$, Brown J: Effect of variation of in witro culture techniques upon oocyte fertilization and embryo development in human in vitro fertilization procedures. Fertil Steril $41: 519,1984$

2. Veeck LLA Oocyte assessment and biological performance. Ann NY Acad Sci $541: 259,1988$

3. Testart J, Belaisch-Allart $\mathbf{J}$, Forman $\mathbf{R}$, Gazengel A, Strubb N, Hazout A, Frydman R: Influence of different stimulation treatments on oocyte characteristics and in-vitro fertilizing ability. Hum Reprod 4:192, 1989

4. Pellicer A, Ruiz A, Castellvi RM, Catalyud C, Ruiz M, Tarín JJ, Miró F, Bonilla-Musoles F: Is the retrieval of high number of oocytes desirable in patients treated with gonadotrophin-releasing hormone analogues (GnRH-a) and gonadotrophins? Hum Reprod 4:536, 1989

5. Plachot M, de Grouchy J, Junca AM, Mandelbaum J, Turleau C, Couillin $\mathbf{P}$, Cohen J, Salat-Baroux J: From oocyte to embryo: A model, deduced from in vitro fertilization, for natural selection against chromosome abnormalities. Ann Génét 30:22, 1987

6. Tarín JJ, Pellicer A: Consequences of high ovarian response to gonadotropins* a cytogenetic analysis of unfertilized human oocytes. Fertil Steril 54:665, 1990

7. Zenzes MT, de Geyter C, Bordt J, Schneíder HPG, Nieschlag E: Abnormalities of sperm chromosome condensation in the cytoplasm of immature oocytes. Hum Reprod 5:842, 1990

8. Quinn P, Warnes GM, Kerin JF, Kirby C: Culture factors in relation to the success of human in vitro fertilization and embryo transfer. Fertil Steril $41: 202$, 1984

9. Tarkowski AK: An air-drying method for chromosome preparation from mouse eggs. Cytogenetics 5:394, 1966

10. Pieters MHEC, Geraedts JPM, Dumoulin JCM, Evers JLH, Bras M, Kornips FHAC, Menheere PPCA: Cytogenetic analysis of in vitro fertilization (IVF) failures. Hum Genet 81:367, 1989

11. Pellicer A, Polan ML, De Cherney AH: Improved oocyte quality through improved ovulation induction. Ann NY Acad Sci 541:46, 1988

12. Badenas J, Santal6 J, Calafell JM, Estop AM, Egozcue J: Effect of the degree of maturation of mouse oocytes at fertilization: a source of chromosome imbalance. Gamete Res 24:205, 1989

13. Testart J, Lassalle B, Frydman R, Belaisch JC: A study of factors affecting the success of human fertilization in vitro. II. Influence of semen quality and oocyte maturity on fertilization and cleavage. Biol Reprod 28:425, 1983 
14. Schmiady H, Kentenich H: Premature chromosome condensation after in-vitro fertilization. Hum Reprod 4:689, 1989

15. Hamilton CJCM, Evers JLH, Tan FES, Hoogland HJ: The reliability of ovulation prediction by a single ultrasonographic follicle measurement. Hum Reprod 2:103, 1987

16. Jagiello G, Ducayen $M$, Fang J-S, Graffeo $J$ : Cytogenetic observations in mammalian oocytes. In Chromosomes Today, Vol 5, Edited by PL Pearson, KR Lewis. John Wiley and Sons, New York, 1974, p 43

17. Wramsby H, Fredga K: Chromosome analysis of human oocytes failing to cleave after insemination in vitro. Hum Reprod 5:137, 1987

18. Pellestor F, Sèle B: Assessment of aneuploidy in the human female by using cytogenetics of IVF failures. Am J Hum Genet 42:274, 1988

19. Plachot M, Junca AM, Mandelbaum J, de Grouchy J, Salat-Baroux J, Cohen J: Chromosome investigation in early life. I. Human oocytes recovered in an IVF programme. Hum Reprod 1:547, 1986 



\section{Triploidy after in vitro fertilization: cytogenetic analysis of human zygotes and embryos}

M.H.E.C. Pieters, ${ }^{1}$ J.C.M. Dumoulin, ${ }^{2}$ R.C.M. Ignoul-Vanvuchelen, M. Bras, ${ }^{2}$ J.L.H. Evers, J.P.M. Geraedts ${ }^{1}$

1. Department of Genetics and Cell Biology, University of Limburg, Maastricht, The Netherlands.

2. Department of Obstetrics and Gynaecology, Academic Hospital Maastricht, The Netherlands.

I In Vitro Fert Embryo Transfer, in press. 


\section{Abstract}

Tripronuclear zygotes obtained from a clinical IVF program were studied cytogenetically. Successful analysis was possible of 42 specimens at the zygote stage and 21 embryos after first or second cleavage division. In the majority of zygotes $(88 \%)$ the expected triploidy was confirmed, whereas only $14 \%$ of embryos had solely triploid cells. Therefore it is concluded that after tripolar cleavage division, many different types of mosaicism may originate from irregular chromosome distributions. Since the findings in individual blastomeres in embryos resulting from multipronuclear zygotes do not reflect the genetic content of the whole embryo, these embryos are less suitable in a model system for preimplantion diagnosis. The distribution of the sex chromosomal types (XXX, XXY, and $\mathrm{XYY}$ ) confirmed theoretical expectations. Since in abortion material or in liveborn triploidy cases the XYY karyotype is hardly ever observed, this indicates that most likely the $69, X Y Y$ karyotype has a very high embryonic mortality.

\section{Introduction}

Triploidy, a chromosomal abnormality leading to external and internal congenital malformations, is considered to be incompatible with life in the human species (1). It is suggested that triploidy should be considered a pathological entity with three clinical forms: early abortion, midtrimester abortion and the birth of triploid fetuses either alive or dead (2). As observed in early abortion material, in triploidy the additional haploid chromosome set mostly is paternal in origin. A less frequent mechanism for the origin of triploidy is the combination of a normal haploid gamete with a diploid gamete, resulting from non-reduction during meiosis (3). In certain instances the origin of triploidy can be explained by a delay in the cortical granule reaction or a breach in the zona pellucida allowing more than one spermatozoon to penetrate the oocyte (4). In vitro, too many active spermatozoa in the insemination droplet could be an additional factor predisposing to triploidy (5).

Despite the lethality of their chromosome complements, early preimplantation stages of triploid embryos can not be distinguished morphologically from those resulting from zygotes with two pronuclei (6). Therefore, in in vitro fertilization (IVF), identification of zygotes with more than two pronuclei is important and the resulting embryos should be excluded from embryo transfer (ET). Before the introduction of in vitro fertilization this chromosomal abnormality in humans could not be investigated in earlier material than spontaneous abortions. In vitro fertilization has provided a source of material for the study of triploid preimplantation embryos. The incidence of tripronuclear zygotes, in human IVF programs, varies between 2 and $9 \%$ (7-13). Although it has 
been demonstrated that zygotes showing three pronuclei are karyotypically indeed triploid (8), several studies of cleavage-stage embryos arising from tripronuclear zygotes revealed karyotypes being either diploid or triploid, or having severely abnormal chromosome complements, including mosaicism $(6,8)$. This study was intended to determine the ploidy of embryos resulting from tripronuclear zygotes. Since the majority of cases were not simply triploid, it was decided to study the zygotes themselves as well. Moreover, attention is focused on different explanations of chromosomal mosaicisms resulting after the first or second cleavage division. Furthermore, the usefulness of triploid embryos as a model for preimplantation diagnosis will be discussed.

\section{Materials and methods}

\section{Patients and stimulation protocols}

In the period of january 1988 until january 1991, 355 IVF cycles were performed for a variety of infertility problems. In this study, only cycles [304] with at least one oocyte fertilized were included.

All patients underwent pharmacologic enhancement of follicular recruitment with clomiphene citrate (CC, Clomid; Gist-Brocades B.V., Leiderdorp, The Netherlands) and/or human menopausal gonadotrophin (hMG, Humegon; Organon, Oss, The Netherlands), and received human chorionic gonadotrophin (hCG, Pregnyl; Organon, Oss, The Netherlands) to induce pre-ovulatory oocyte maturation and ovulation.

Study groups were devided according to their stimulation protocol. Group I received $50 \mathrm{mg} C \mathrm{C}$ starting between cycle day 3 and 7 , and hMG 150 IU i.m. daily from cycle day 6 till the mean of three perpendicular dimensions of the leading follicle was $16 \mathrm{~mm}$ or above. Patients in group II received hMG 225 IU i.m. daily from cycle day 3 , till the mean diameter of the leading follicle was $16 \mathrm{~mm}$ or above. Patients in group III received the same treatment schedule as patients in group 2, however, pituitary suppression was induced using a gonadotrophin-releasing hormone agonist (GnRH-a, Suprefact; Hoechst B.V., Amsterdam, The Netherlands), $3 \times 100 \mathrm{mg}$ q.i.d. In this group, stimulation of follicular development was continued till the mean diameter of the leading follicle reached at least $18 \mathrm{~mm}$, since no risk of premature luteinization existed. Follicular development was assessed by serum 17-B-estradiol assays, and serum luteinizing hormone (LH) levels were monitored to detect premature luteinization, both by radio-immunoassay techniques in blood samples collected daily. Vaginal ultrasound was used to measure follicle growth, and to determine the number of follicles. In each group hCG 10,000 IU i.m. were administered as soon as the maximum follicular diameter was reached. All ovum retrieval procedures were carried out by means of transvaginal ultrasound guided puncture, $34 \mathrm{~h}$ after hCG. Full 
details of the procedure have been given elsewhere (14). As soon as the oocytes were obtained they were transported to the laboratory. Semen was produced approximately $2 \mathrm{~h}$ after the ovum pick-up. Whittingham's T6 (15) medium supplemented with $10 \%$ inactivated maternal serum was used both for the culture of oocytes and embryos and for washing and incubation of the spermatozoa (16). The oocytes were preincubated for 5 $h$ and about 50,000 motile sperm were added to the oocyte in $1 \mathrm{ml}$ medium in a 4-well multidish (Nunc; Life Technics BV, Breda, The Netherlands). At $16-20 \mathrm{~h}$ after insemination the cumulus cells were removed mechanically and the oocytes were examined for the presence and number of pronuclei.

Zygotes showing more than two pronuclei were not used for embryo transfer. Informed consent was obtained from the patients to further investigate these zygotes. Tripronuclear zygotes were transferred (prior to pronuclear disappearance $[n=60]$, or after the first or second cleavage division $[\mathrm{n}=57]$ ) into $1 \mathrm{ml}$ culture medium containing $150 \mu \mathrm{l}$ colcemid (10 $\mu \mathrm{g} / \mathrm{ml}$ ) solution (Gibco, UK) for 24 hours to arrest cleavage at metaphase stage.

\section{Cytogenetic analysis}

Chromosome preparation of the zygotes and embryos was performed according to the air-drying method of Tarkowski (17) with some modifications (18). The zygote respectively embryo was placed in a hypotonic (1\%) sodium-citrate solution for about 10 minutes. Subsequently the zygote or embryo was placed in a microdrop of the same solution on a grease-free slide. Most of the solution was carefully removed. Gradual fixation was done in three steps: first, a drop of absolute methanol was added and rapidly after this, a drop of an acetic acid:methanol (v:v = $1: 5)$ solution, and finally a drop of an acetic acid:methanol (v:v $=1: 3$ ) solution. The slide was dried and preparations were stained in a $10 \%$ Giemsa solution. If spread sufficiently, the chromosomes of the tripronuclear zygotes were examined using trypsin/EDTA Giemsa banding (19) or dystamicin/DAPI banding technique (20) in order to determine the presence of a $\mathrm{Y}$ chromosome. Since it is clear from other studies that chromosome number and constitution of individual cells differ extremely after cleavage division, instead of using exact chromosome numbers ploidy levels of metaphases were assessed. To determine the type of mosaicism, embryos were scored on the basis of the scheme given in Figure 1. 

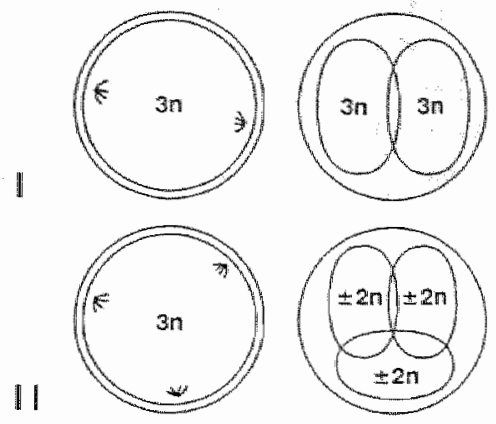

III

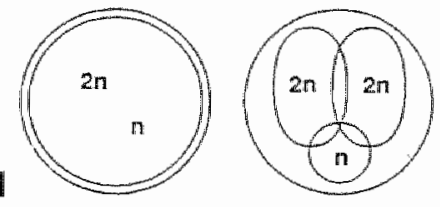

IV

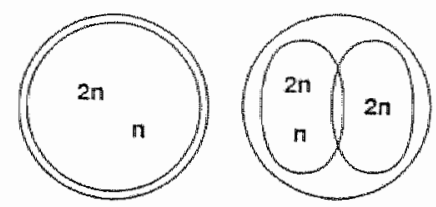

V

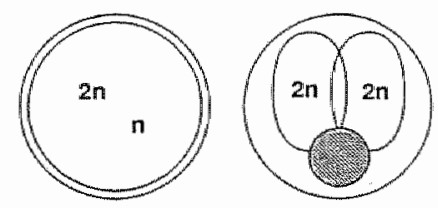

Figure 1. Classification of the chromosomal findings after cleavage division

I. All chromosomes gather on metaphase plate, division is regular and daughter cells are fully triploid (3n) (Ref.:4,6)

II. Movement of chromosomes on tripolar spindle is disorganized if division in 3-cell embryo occurs, metaphases will be approximately diploid but different in each individual cell $(3 \mathrm{x} \pm 2 \mathrm{n})(\mathbb{R e f}: 21,22)$

III. Extrusion of haploid nucleus leading to haploid and diploid mosaicism within one embryo $(\mathrm{n} / 2 \mathrm{n})(\operatorname{Ref}: 9,22)$

IV: Extrusion of haploid nucleus which is incorporated in one of the cells after first cleavage division. In the embryo diploid and triploid cells are found $(2 \mathrm{n} / 3 \mathrm{n})(\operatorname{Ref} .6)$

V. Extrusion and degeneration of haploid nucleus leading to a "normal" diploid embryo. Embryonic development depends on the nature of the extruded nucleus (Ref.:6)

\section{Statistics}

Statistical evaluation was performed using the $x^{2}$ test for the total group or the Student's $t$ - test for the values per individual patient.

\section{Results}

Clinical parameters as maternal age (table I), hormonal stimulation (table II), and cause of infertility (table III) were evaluated with respect to the incidence of triploidy. The investigated parameters only showed slight differences for the occurrence of triploidy in tubal pathology (92 
out of 1576) versus non-tubal pathology (41 out of 1069). The occurrence of triploidy was low in the group of male subfertility couples. Since numbers in this group were small no statistical test was performed. A significant difference $(P<0.001)$ was found with respect to the fertilization rates in favour of cycles with, as compared to cycles without tripronuclear zygotes (table IV).

Table I. Maternal age, fertilization rate*, and frequency of triploidy in IVF

\begin{tabular}{lccc}
$\begin{array}{l}\text { Maternal } \\
\text { age }\end{array}$ & $\begin{array}{c}\text { No. of } \\
\text { Cycles }\end{array}$ & $\begin{array}{l}\text { Fertilization } \\
\text { Rate }(\%)\end{array}$ & $\begin{array}{c}\text { p pronuclei } \\
(\%)\end{array}$ \\
\hline$\leq 35$ & 212 & $1391 / 1992(69.8)$ & $92(4.6)$ \\
$>35$ & 92 & $484 / 653(74.1)$ & $41(6.3)$
\end{tabular}

* fertilization rate $=$ two or more pronuclei at $18-20 \mathrm{~h}$ after insemination

Table II. Hormonal stimulation, fertilization rate*, and occurence of triploidy in IVF

\begin{tabular}{lccc}
$\begin{array}{l}\text { Hormonal } \\
\text { stimulation }\end{array}$ & $\begin{array}{c}\text { No. of } \\
\text { Cycles }\end{array}$ & $\begin{array}{l}\text { Fertilization } \\
\text { Rate(\%) }\end{array}$ & $\begin{array}{c}3 \text { pronuclei } \\
(\%)\end{array}$ \\
\hline hMG & 34 & $172 / 252(68.3)$ & $11(4.4)$ \\
CC/hMG & 87 & $382 / 543(70.3)$ & $24(4.4)$ \\
GnRH-a/hMG & 183 & $1321 / 1850(71.4)$ & $98(5.3)$
\end{tabular}

* fertilization rate $=$ two or more pronuclei at $18-20 \mathrm{~h}$ after insemination 
Table III. Indication for IVF, fertilization rate*, and incidence of triploidy in IVF

Indication

No. of

Cycles

Fertilization

Rate (\%)

3 pronuclei $(\%)$

Tubal

Unexplained

Endometriosis

Male

177

77

$1182 / 1576(75.0)$

$92(5.8)^{\mathrm{a}}$

Other *

* fertilization rate $=$ two or more pronuclei at $18-20 \mathrm{~h}$ after insemination

a $: P<0.05$ (Chi-square)

\# immunologic factors(7), ovulation disorders(7) and 'donor' (6)

Table IV. Fertilization in cycles with and without tripronuclear zygotes

No. of

Cycles

Fertilization

Rate $(\%)$

99 with 3PN

205 without $3 \mathrm{PN}$

$855 / 1072(79.8)$

$1020 / 1573(64.8)^{a}$

with 3PN: at least one tripronuclear zygote,

without 3PN:IVF cycles with fertilized oocytes but no tripronuclear zygote was found.

${ }^{\mathrm{a}}: P<0.001$ (Student T-test)

\section{Ploidy findings in embryos}

In 21 out of 57 embryos arrested after first or second cleavage division, ploidy levels of individual blastomeres could be determined. The tripronuclear zygotes had divided to 2-6 blastomeres. Sixteen embryos could not be analysed because they showed only interphase nuclei and/or prophasing chromosomes. Twenty embryos were not analyzable either because of fragmentation/degeneration [10] or preparation failure [10]. Results from ploidy analysis of individual cells and resulting mosaicism type are summarized in table V. Of 21 analyzable embryos only $3(14 \%)$ were completely triploid whereas $15(71 \%)$ showed variations in chromo- 
some number of individual cells which revealed non-overlapping metaphases from more or less haploid to tetraploid (mosaics). Mosaicisms classified as type II $( \pm 2 n)$ or III $(2 n / n)$ (Fig. 1) were observed in 6 and 5 cases respectively. A triploid/diploid mosaicism (type IV, Fig. 1) was found in 2 embryos. Three embryos showed only one metaphase plate which prevented ploidy analysis.

\section{Chromosomal analysis of tripronuclear zygotes}

Sixty tripronuclear zygotes were arrested before the first cleavage division. Preparation failure occurred in 10 cases, and 8 zygotes were not analyzable because of degeneration of chromosomes, interphase nuclei or prophasing chromosomes only found. In the majority $(37 / 42=88 \%)$ of the analyzable zygotes the triploidy could be confirmed. Sixteen zygotes showed three haploid metaphases, eight zygotes showed one diploid and one haploid metaphase, and 13 zygotes had a total chromosome number which was approximately triploid. In five zygotes a different ploidy from the expected triploidy was found: Two zygotes had a diploid chromosome number and three zygotes were (hyper)tetraploid. In 27 tripronuclear zygotes the exact chromosome number could be shown to vary from 60 to 71. In three cases it was possible to estimate the chromosome numbers from the three individual nuclei. One case revealed a $22, X,-E ; 23, X$ and a $25, \mathrm{X},+\mathrm{X},+\mathrm{B}$ karyogram (Fig. 2). Using dystamycin/DAPI staining it was possible to identify an extra chromosome 16 in a zygote with 70 chromosomes; nuclei were considered to be $24, X,+16 ; 23, X$ and $23, Y$ (Fig. 3). In 24 of the 35 triploid zygotes chromosome analysis could be performed using either DAPI or Giemsa banding technique. With respect to the sexchromosome constitution it was found that out of 24 triploid zygotes 11 $(46 \%)$ zygotes had one $Y$-chromosome and five zygotes $(21 \%)$ had two Y-chromosomes (Fig. 4). 
Table V. Ploidy of individual nuclei and classification of tripronuclear embryos with one or more metaphase

Code No. of Ploidy estimation of individual nuclei Classification $\begin{array}{llllllll}\text { Cells } & 1 & 2 & 3 & 4 & 5 & 6 & \text { type }\end{array}$

$119.50 \quad 3$

D D i

$122.30 \quad 3$

H D D

TE i i

$122.40 \quad 6$

$133.30 \quad 4$

$147.50 \quad 6$

D D $\mathrm{H}$

H D i

TR TR

$152.80 \quad 2$

D D

$\mathrm{H}$

TR TR

$164.40 \quad 2$

$167.40 \quad 6$

$171.40 \quad 2$

D D

D

D

D i

TR TR

$192.40 \quad 4$

D TR

D

D

$216.10 \quad 3$

D $p \quad p$

$228.11 \quad 3$

D $\mathrm{H} \quad \mathrm{H}$

$234.40 \quad 6$

$274.50 \quad 5$

$297.51 \quad 4$

D $\mathrm{H} \quad \mathrm{H}$

TR i

$297.52 \quad 4$

D TE i

$297.71 \quad 5$

$297.72 \quad 6$

D D

D

D $\quad$ D $\quad$ D

$308.50 \quad 4$

$375.20 \quad 5$

D D i

D D H

D TR i

i $\quad$ i i

II

III

N.A.

III

III

I

III

I

II

I

IV

N.A.

II

III

N.A.

II

II

II

III

IV

H (approximately haploid) $=<34$ chromosomes

$D$ (approximately diploid) $=34-58$ chromosomes

TR (approximately triploid) $=59-81$ chromosomes

TE (approximately tetraploid) $=\geq 82$ chromosomes

$i=$ interphase

$\mathrm{p}=$ prophase

N.A. = Not Analyzable

* see discussion 


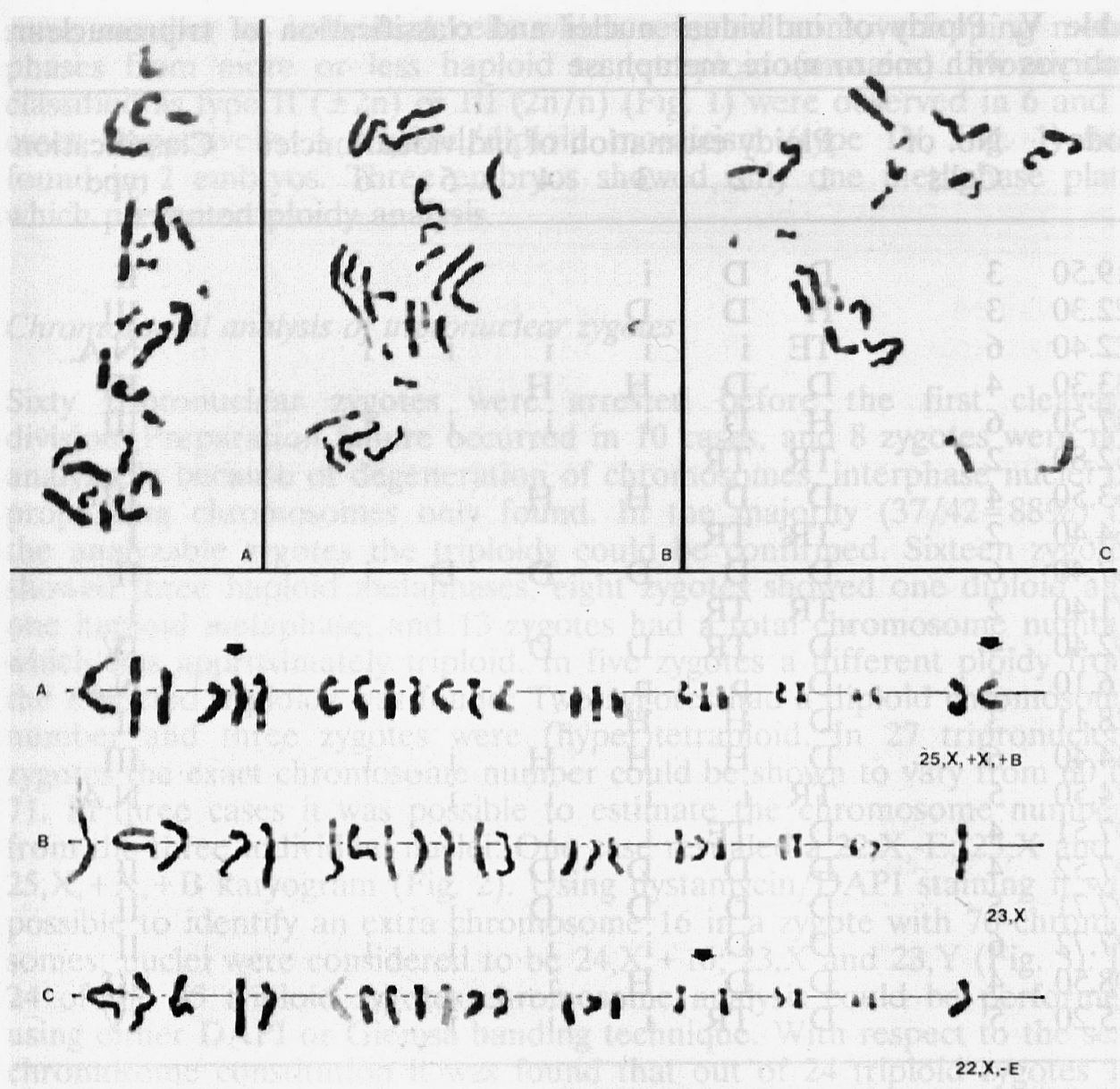

Figure 2. Three individual metaphases of a tripronuclear zygote (Giemsa-banding). A. $25, \mathrm{X},+\mathrm{X},+\mathrm{B}$; B. $23, \mathrm{X}$; C. $22, \mathrm{X},-\mathrm{E}$ 


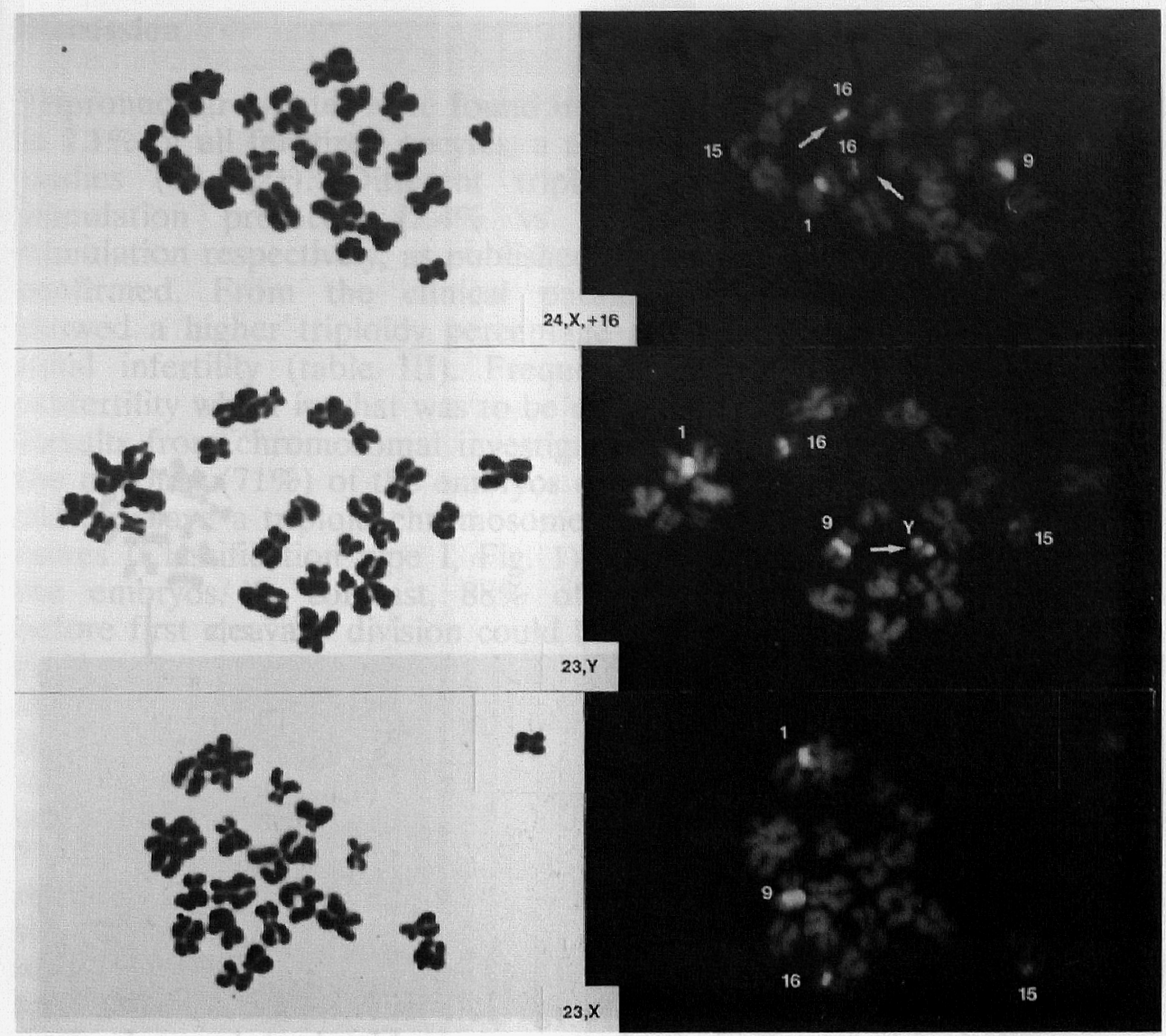

Figure 3. Three individual metaphases of a tripronuclear zygote (DAPI-banding). A. $24, \mathrm{X},+16$; B. $23, \mathrm{Y}$; C. $23, \mathrm{X}$ 


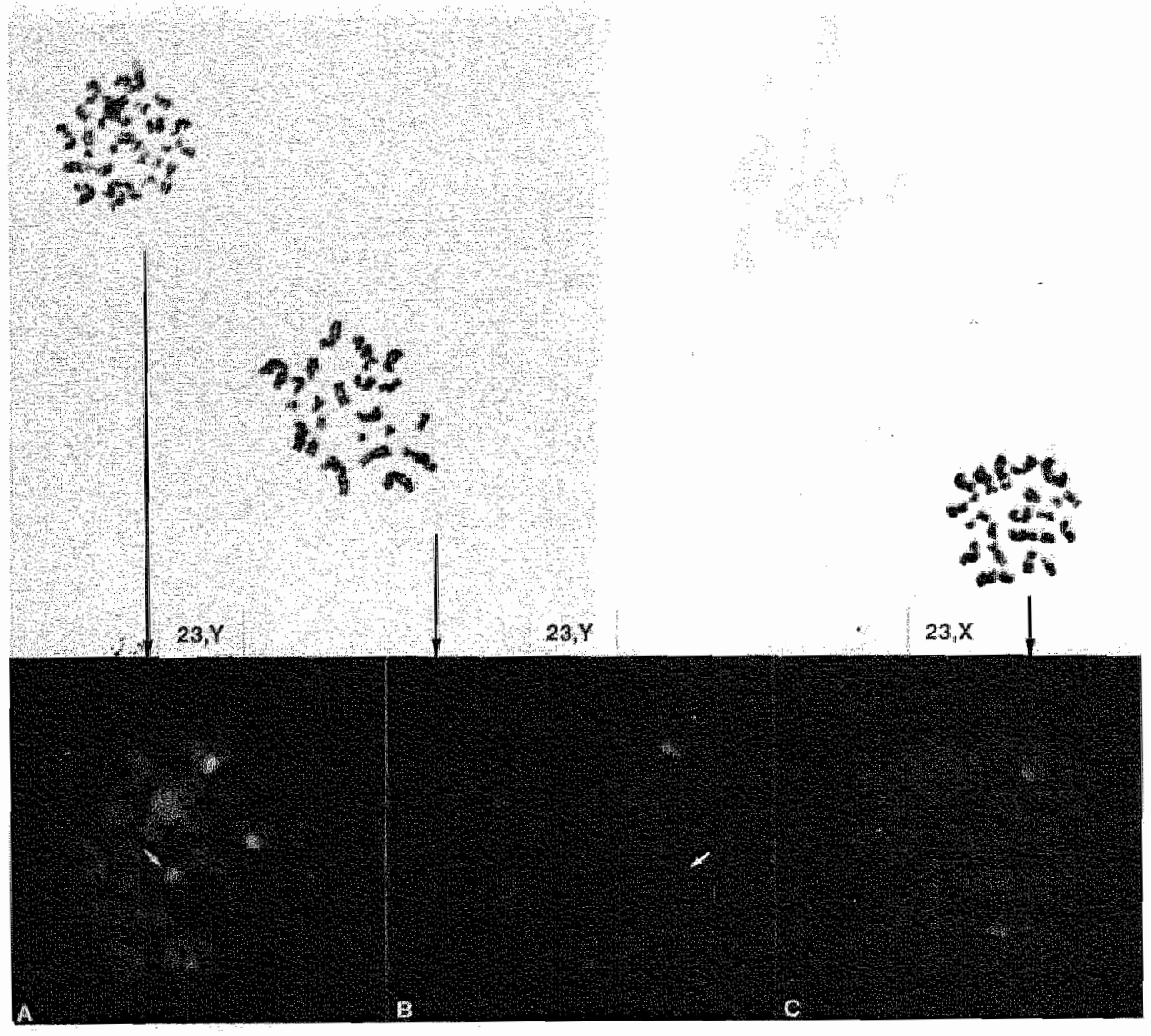

Figure 4. Three individual metaphases of a tripronuclear zygote (DAPI-banding). A. $23, \mathrm{Y}$; B. $23, \mathrm{Y}$; C. $23, \mathrm{X}$ 


\section{Discussion}

Tripronuclear zygotes were found in $5.0 \%$ of all inseminated oocytes, and in $7.1 \%$ of all fertilized oocytes, a result comparable to that of published studies $(10,11,21)$. Different triploidy rates for different hormonal stimulation protocols $[2.4 \%$ vs $7.0 \%$ in $\mathrm{hMG}$ and $\mathrm{LHRH} / \mathrm{hMG}$ stimulation respectively, as published by Plachot et al. (12)], could not be confirmed. From the clinical parameters evaluated tubal infertility showed a higher triploidy percentage $(P<0.05)$, as compared to nontubal infertility (table III). Frequency of triploidy was low in male subfertility which is what was to be expected in these patients.

Results from chromosomal investigation showed that the blastomeres of the majority $(71 \%)$ of the embryos developing from tripronuclear zygotes did not have a triploid chromosome complement. Triploidy in all blastomeres (Classification type I, Fig. 1) could only be confirmed in $14 \%$ of the embryos. In contrast, $88 \%$ of the tripronuclear zygotes arrested before first cleavage division could be confirmed as being triploid. These findings are comparable to those found in other studies $(11,22)$. As shown in table $\mathrm{V}$, different types of mosaicism were observed in embryos resulting from tripronuclear zygotes. Since 2-cell embryos only contained regular triploid cells and embryos immediately dividing in more than two cells show all kinds of numerical aberrations (Classification type II-III-IV, Fig. 1) this suggests that the critical period at which these anomalies arise must be in between the time of first spindle formation and the subsequent early cleavage division. In case of tripolar cleavage division, mosaicisms can be found because of irregular chromosome distribution. In the rat most of the first cleavage division spindles of dispermic zygotes were observed to be bipolar, a tripolar spindle was observed on one occasion (23). In sea-urchins, however, tripolar or multipolar cleavage occurs after fertilization by two or more spermatozoa (24). Whether bipolar or tripolar spindle formation in human zygotes depends on the number of penetrated spermatozoa is not yet clear.

In spite of all possible explanations, one type of mosaicism could not be classified according to the expectations based on previous studies (Fig. 1). In case 297.51 (Table V) an approximately diploid and an approximately tetraploid metaphase were found, next to two interphase nuclei. This type of mosaicism can either be caused by tripolar division of the metaphase plate and cytoplasm division in 2 cells, or nondivision of one of the approximately diploid cells after chromosome replication thereby duplicating its original chromosome number.

A multipronuclear zygote becoming a perfectly normal diploid embryo by selective nuclear loss during the first cleavage division (Classification type V, Fig. 1) as proposed by Rudak et al.(8) was not observed. However, eight one-cell zygotes showed one diploid metaphase and in addition one separated haploid metaphase. Development of diploid embryos requires the extrusion of a haploid nucleus. If, in case of dispermy, a male pro- 
nucleus is extruded a normal diploid genome will remain. If however the female pronucleus is extruded a hydatidiform mole may develop. In case of a digynic triploidy, extrusion of the paternal pronucleus will lead to a relatively good embryonic development but very poor development of the membranes and placenta in mice (25).

In spite of colcemid incubation, a considerable number [16] of the embryos showed interphase and/or prophasing chromosomes. Probably these embryos were already spontaneously arrested without colcemid influence. Embryos having significant numerical chromosome abnormalities will probably die shortly after a few mitotic divisions since disturbance in the distribution of chromosomes is evident. Pregnancy will rarely last long enough to be recognized, even as an abortion. The phenomenon of irregular chromosome distribution could be one of the first steps to the natural elimination of abnormal conceptuses (11). Tripronuclear zygotes developing beyond the implantation stage may be those showing regular triploidy, as ascertained in $1 \%-3 \%$ of clinically recognized conceptions (3).

Five out of 40 tripronuclear zygotes investigated in this study were not triploid whereas the zygote had been diagnosed as having three pronuclei. Three zygotes showed a tetra- or hypertetraploid chromosome number and two zygotes showed a diploid chromosome number. In case of diploidy it is asssumed that a cytoplasmic vacuole has been misjudged and interpreted as a pronucleus. Cytoplasmic vacuoles can have a pronuclear dimension and aspect and are therefore called pseudopronuclei (26). Tetraploidy in a tripronuclear zygote can either be caused by 1 ; one diploid and two haploid gamete nuclei or 2; penetration of a spermatozoon in the time of or after the colcemid incubation (in this way the fourth nucleus can escape detection). It is not clear whether diploid nuclei can be recognized by the dimensions of the pronucleus. Most probably, triploidy arising from one haploid and one diploid maternal or paternal nucleus will never be recognized in routine IVF procedures in which triploidy is only based on morphological aspects (i.e., observation of three pronuclei). Whether a failure in the second maternal meiosis can lead to an extra maternal pronucleus is unknown, if not, the observation of three pronuclei implies the penetration of two spermatozoa (dispermic).

Nine individual nuclei (three zygotes) were available for analysis and a numerical abnormality was found in three metaphases. Presuming that nuclei with 23 chromosomes were not pseudohaploid (i.e., one missing chromosome in a group together with an extra chromosome of the same group), one-third of the nuclei were abnormal which is in agreement with other studies (12). The finding of a chromosome number substantially less than the triploid number in 9 out of 27 zygotes is probably a result from the preparation.

Sex-chromosomal constitution was analysed either on the basis of Giemsa banding or on the finding of one or two Y-chromosomes after 
dystamicin/DAPI banding. As found by Jacobs et al. (3) it is assumed that in abortion material, the additional haploid set mostly derives from the father. $\mathrm{XXX}-\mathrm{XXY}$-, and $\mathrm{XYY}$-karyotypes might then be expected in $25 \%, 50 \%$ and $25 \%$ respectively. In WF it can not be proven whether tripronuclear zygotes are diandric or digynic. If male and female gametes have an equal chance to participate in triploidy then $\mathrm{XXX}, \mathrm{XXY}$, and $X Y Y$ constitution might be found in a $2: 3: 1$ ratio $(33-50-17 \%)$. Finding that five out of 24 zygotes showed two Y-chromosomes means that the observed rate of $21 \%$ is in between the calculated percentages 17 and 25 . Therefore we conclude that, in the present study of tripronuclear zygotes and resulting preimplantation embryos (in contrast to abortion material and liveborns), the triploid 69,XYY karyotype occurs as frequently as can be calculated on a theoretical basis. Either XYY is found in higher rates as a consequence of fertilization in vitro rather than in vivo, or, more likely, the $69, X Y Y$ karyotype has a very high embryonic mortality (8).

While the use of human embryos for experimental purposes continues to be restricted because of ethical reasons, embryos resulting from multipronuclear zygotes are used for the study of early preimplantation stages. In the zygotes it is possible to study the chromosomal content of the gametes which produce the embryos in vitro. As a model for preimplantion sex diagnosis triploid zygotes are perfect cells. However, sex assignement on the basis of analysis of individual blastomeres of triploid human embryos is unreliable since in a large proportion of cases random division results in individual cells having different chromosomal constitutions. Individual cells of tripronuclear embryos can be studied using new techniques as in situ hybridization and polymerase chain reaction. Nevertheless, it should be kept in mind that in these embryos single cells do not reflect the constitution of the whole embryo.

\section{Acknowledgements}

The authors wish to thank Francis van der Lubbe for her excellent photography. This investigation has been supported by the foundation for Medical and Health Research NWO (grant no. 900-504-067). 


\section{References}

1. Chatterjee MS, Tejani MA, Verma UL, Weiss RR: Prenatal diagnosis of triploidy Int J Gynaecol Obstet $1983 ; 21: 155-157$

2. Monrozies $X$, Monroxies $\mathbf{M}$, Parinaud $J$, Berrebi A: La triploidie. J Gynecol Obstet Bilol Reprod Paris 1986,15:893-900

3. Jacobs PA, Angell RR, Buchanan IM, Hassold TJ, Matsuyama AM, Manuel B: The origin of human triploids. Ann Hum Genet (Lond.) 1978:42:49-57

4. Kola I, Trounson A: Dispermic human fertilization: violation of expected cell behavior. In Schatten $\mathrm{H}$, Schatten $\mathrm{G}$ (Eds) The cell biology of fertilization. San Diego, Academic Press, 1989, pp 277-293

5. Edwards RG: The Case for studying human embryos and their constituent tissues in vitro. In Edwards RG, Purdy JM (Eds) Human conception in vitro. Proceedings of the first Bourn Hall meeting, London, Academic Press, 1982, pp $370-388$

6. Angell RR, Templeton AA, Messinis IE: Consequences of polyspermy in man. Cytogenet Cell Genet 1986;42:1-7

7. Mahadevan $\mathbf{M M}$, Trounson $\mathbf{A O}$ : The influence of seminal characteristics on the success rate of human in vitro fertilization. Fertil Steril $1984 ; 42: 400-405$

8. Rudak E, Dor J, Mashiach S, Nebel L, Goldman B: Chromosome analysis of multipronuclear human oocytes fertilized in vitro. Fertil Steril 1984;41:538-545

9. Michelmann HW, Bonhoff A, Mettler L: Chromosome analysis in polyploid human embryos. Hum Reprod 1986;1:243-246

10. Wentz CA, Repp JE, Maxson WS, Pittaway DE, Torbit CA: The problem of polyspermy in in vitro fertilization. Fertil Steril 1983;40:748-754

11. Macas E, Suchanek E, Grizelji V, Puharic I, Simunic V: Chromosomal preparations of human triploid zygotes and embryos fertilized in vitro. Eur I Obstet Gynecol \& Reprod Biol 1988;29:299-304

12. Plachot $M$, Veiga A, Montagut J, de Grouchy J, Calderon G, Lepretre S, Junca A-M, Santalo J, Carles E, Mandelbaum J, Barri P, Degoy J, Cohen J, Egozcue J, Sabatier JC, Salat-Baroux J: Are clinical and biological IVF parameters correlated with chromosomal disorders in early life: a multicentric study. Hum Reprod $1988 ; 3 ; 627-635$

13. Al-Hasani $S$, Ven van de $H$, Diedrich $K$, Hamerich $U$, Lehmann $F$, Krebs D: Polyploidien bei der In-vitro-fertilisation menschlicher Eizellen: Häufigkeit und mögliche Ursachen. Geburtsh u Frauenheilk 1984;44:395-399

14. Evers JLH, Falck Larsen J, Gnany GG, Sieck UV: Complications and problems in transvaginal sector scan-guided follicle aspiration. Fertil Steril 1988;49:278-282 
15. Quinn P, Warnes GM, Kerin JF, Kirby $\mathbf{C}$ : Culture factors in relation to the success of human in vitro fertilization and embryo transfer. Fertil Steril $1984 ; 41: 202-209$

16. Dumoulin JCM, Evers JLH, Offermans JPM, Bras M, Pieters MHEC, Geraedts JPM: Human in vitro fertilization using spermatozoa capacitated in hyperosmotic media. Gynecol Obstet Invest 1990;30:165-168

17. Tarkowski AK: An air-drying method for chromosome preparation from mouse eggs. Cytogenetics $1966 ; 5: 394-400$

18. Pieters MHEC, Geraedts JPM, Dumoulin JCM, Evers JLH, Bras M, Kornips FHAC, Menheere PPCA: Cytogenetic analysis of in vitro fertilization (IVF) failures. Hum Genet 1989;81:367-370

19. Seabright M: Rapid banding technique for human chromosomes. Lancet $1971 ; \mathrm{II}: 971-972$

20. Schweizer D, Ambros P, Andrle M: Modification of DAPI banding on human chromosomes by prestaining with a DNA-binding olipeptide antibiotic, dystamicin A. Exp Cell Res 1978;111:327-332

21. Plachot M, Mandelbaum J, Junca A, de Grouchy J, Salat-Baroux J, Cohen J: Cytogenetic analysis and developmental capacity of normal and abnormal embryos after IVF. Hum Reprod 1989;4:Suppl. 99-103

22. Kola I, Trounson A, Dawson G, Rogers P: Tripronuclear humam oocytes: altered cleavage patterns and subsequent karyotypic analysis of embryos. Biol Reprod 1987;37:395-401

23. Austin CR, Walton A: Fertilization. In Parkes AS (Ed) Marshall's physiology of reproduction. London, Longmans, 1960, pp 310-416

24. Wilson EB: The Cell in Development and hereditary. New York, Macmillan 1928, pp 916-979

25. Reik W: Genomic imprinting and genetic disorders in man. Hum Genet Dis $1989 ; 5: 331-336$

26. Van Blerkom J, Bell $\mathbf{H}$, Henry G: The occurence, recognition and developmental fate of pseudo-multipronuclear eggs after in-vitro fertilization of human oocytes. Hum Reprod 1987;2:217-225 


$$
\text { : }
$$

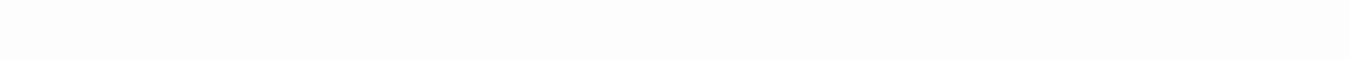
(1) (1) . .

(1) 
Chapter VII

General discussion 


\section{Introduction}

The introduction of IVF as a treatment modality for infertility has not only offered a fair chance of a pregnancy to patients who previously would have been unable to bear a child of their own, it also has disclosed exciting new areas of studying human reproduction. Whereas before 1978 the investigation of infertility was virtually restricted to counting sperms and testing tubal patency, IVF has shed new scientific light on the process which is crucial to human reproduction as such: fertilization. Especially fertilization failures have revealed some of the delicate mechanisms involved in the complex process of human gamete fusion and the subsequent preimplantation development. The aim of the present study was to increase our understanding of cytogenetic factors involved in these processes.

The study was designed to investigate sperm penetration, aspects of fertilization and chromosome condensation in human oocytes considered to be unfertilized after IVF treatment. In the mean time a method of fluorescence in situ hybridization was developed to study gametes, zygotes, and preembryos as an alternative method for chromosomal studies. A comparison was made between the influence of different stimulation protocols on the oocyte maturation and aneuploidy. Preembryos resulting from tripronuclear zygotes were studied regarding chromosomal mosaicism after cleavage divisions.

The findings of the present study should be interpreted within the framework of the IVF-treatment they were obtained from. The oocytes were collected after ovarian stimulation during pituitary suppression, and fertilization was achieved under in vitro conditions after pretreatment of the male and female gametes in the laboratory. Also, the patients did not form a representative sample of the general population, since they differed in several aspects, of which age was probably the most important one.

\section{Fertilization abnormalities}

Sperm penetration of oocytes may occur at any stage of oocyte maturation (Acosta et al., 1988). In IVF, cytogenetic analysis of the first and second metaphase stages may provide information on the nuclear maturity. After oocyte penetration, the process of sperm decondensation requires oocyte factors which are as yet not fully investigated. In IVF failures, sperm penetration without decondensation is frequently observed (Chapter II). It is thought to represent the permanent arrest of the oocytes at metaphase II stage with the persisting presence of cytoplasmic chromosome condensing factors (Schmiady et al., 1986). A certain degree of maturation of the oocyte cytoplasm is required for formation of the male pronucleus. Finding sperm chromosomes in oocytes which, in the 
routine laboratory examination, had been qualified as 'unfertilized" (i.e, no pronuclei and no cleavage), indicates fertilization arrest to have occurred after penetration of the oocyte by the spermatozoon. Maturation related oocyte factors may be responsible for this kind of defect. The ovulation induction protocol is of influence in this respect (Chapter V). Both, cytogenetic proven presence or absence of sperm penetration, may determine the prognosis for further treatment. Triploidy in IVF is found in about $5 \%$ (Chapter VI). Most probably, triploidy is more frequent after in vitro than after in vivo fertilization. In the latter situation the percentage is minimally about one. This figure is calculated as the product of the frequency of spontaneous abortions recognized and the frequency of triploidy among those (Dyban and Baranov, 1987). In studies of abortion material and liveborns, dispermy is demonstrated in two-thirds of all triploids. Even in IVF-failures (no pronuclei and no cleavage) triploidy may be found. Of all preparations showing a triploid chromosome number, $75 \%$ were found to be the result of a normal fertilization of an unreduced (diploid) oocyte. For that reason it is hypothesized that triploids resulting from unreduced oocytes are frequently eliminated spontaneously by cleavage arrest because of oocyte immaturity.

\section{Gamete abnormalities}

Chromosomal defects are among the most common causes of genetic disorders and are responsible for the largest proportion of miscarriages. Since reproduction involves the combination of male and female gametes, it is to be expected that most of the chromosomal defects may already be found in either of the gametes.

Oocyte preparation and analysis are technically difficult and strict criteria for analysis are lacking. In human oocytes chromosomal banding, to identify individual chromosomes, is seldomly successful. Such limitations in the karyotyping of metaphase II cells represent a serious obstacle in making an accurate diagnosis of specific aneuploidy or structural rearrangements. Up to now, most of the karyotypes reported in human oocytes have been based on conventionally stained chromosomes. The overall frequency of abnormalities in mature oocytes was recently reported to be $22.4 \%$ with a vast majority of numerical $(95 \%)$ over structural aberrations (5\%) (Pellestor, 1991). The low percentage of structural abnormalities could be explained by the difficulty to detect these abnormalities. Because of insufficient chromosome identification in oocytes, pseudohaploidy may also be missed. The use of two different hormonal stimulation protocols did not reveal different nondisjunction percentages (Chapter V). Chromosomal aberrations observed in human oocytes may contribute to abnormal preimplantation development in vitro (Macas et al., 1990). Aneuploidy is assumed to be responsible for a 
major portion of pregnancy wastage after IVF (Michaeli et al., 1990). Pregnancies achieved by IVF and resulting in blighted ova were karyotyped, the rate of aneuploidy was found to be $38 \%$ (Roesler et al, 1989). However, this percentage could be higher, since this study involved only 13 pregnancies. Furthermore, pregnancy wastage after IVF is normally not recognized and takes place at a stage earlier than blighted ovum.

Technical restrictions for analysis also hold through for human spermatozoa. In the past, chromosomal investigation of human spermatozoa was mainly possible by studying chromosomal polymorphisms in abortion material (Meulenbroek and Geraedts, 1982). A milestone in the analysis of spermatozoa was the introduction of a test using zona-free hamster ova (Rudak et al., 1978). Chromosomal analysis of spermatozoa penetrated in these hamster ova showed an overall aneuploidy percentage of about 4\% (Martin and Rademaker, 1990). However, it has to be noted that these results are obtained from spermatozoa capable of oocyte penetration and therefore aneuploidy score may be underestimated. With the introduction of in situ hybridization it has become possible to estimate chromosomal non-disjunction in unselected spermatozoa (Chapter IV). Until now this technique has been used in a few studies only and an overall percentage of the aneuploidy rate can not yet be given. However, an increasingly wide range of chromosome specific probes is becoming available and with improved preparation of nuclei it should be possible to obtain data for all chromosomes within the next few years.

\section{Technical developments}

Despite technical developments of analysis at the chromosome level it is clear that more insight at the DNA level may only be obtained by the further development and refinement of molecular techniques. During recent years important progress has been achieved by the introduction of fluorescent in situ hybridization (FISH) and the polymerase chain reaction (PCR).

PCR has enabled scientists to specifically amplify DNA sequences of interest over one-millionfold. However, this method is limited by the fact that small fragments of contaminating DNA sequences may interfere with the reliability of the diagnosis. Moreover, the diagnosis of numerical chromosome abnormalities via PCR techniques is unlikely. The PCR technique is a method to amplify the amount of a specific DNA sequence many times. Therefore it is ideal for the amplification and detection of differences at the DNA level. It cannot very easy be used for the detection of the difference between 2 and 3 DNA strands with the same sequence, since this quantitative difference disappears during an amplification which is more than a millionfold. 
The application of micromanipulative techniques at the zygote and preembryo level is still in the research phase but has already allowed for assisted fertilization and microbiopsy ( $\mathrm{Ng}$ et al,, 1990). To perform genetic diagnosis on human preembryos one or more representative cells should be obtained. Human preimplantation development in vitro is not adversely affected by biopsy at the 8-cell stage (Hardy et al., 1990). For an accurate diagnosis, it may be necessary to biopsy more than one cell from each embryo, possibly at the blastocyst stage. Moreover, trophectoderm biopsy has the advantage that only extra-embryonic cells are removed in contrast to a biopsy from a 4- to 8-cell embryo (Dokras et al., 1990). Whether biopsied blastocysts implant at a rate comparable to that of normal blastocysts is not yet known.

In IVF, induction of multiple follicle development has been introduced to allow the harvest of more than one mature oocyte. A related advantage, especially in the early days of IVF, when oocyte retrieval was performed laparoscopically under general anesthesia, was the reduced need for multiple retrievals. Replacement of more than one preembryo increases the risk of multiple pregnancy with accompanying complications. Fortunately, since the introduction of ultrasound guided transvaginal oocyte retrieval, the IVF procedures are less demanding. In an attempt to decrease the number of multiple gestations after IVF, efforts have been made to reduce the maximum number of preembryos replaced. Present day, laboratory techniques have allowed reducing the number of preembryos to be transferred from 4 to 3 , and recently even to 2 , thereby decreasing the number of quadruplets and triplets without affecting the eventual pregnancy rate (Huisman et al., 1991). A return to the natural cycle has been studied as a realistic alternative to ovarian hyperstimulation and pituitary suppression for IVF (Foulot et al., 1989). The benefit of natural cycles should also be taken into consideration when thinking about the clinical implications.

\section{Clinical implications}

The revolution in molecular genetics will provide medical science with sophisticated, more sensitive methods for prenatal genetic diagnosis. Assisted reproductive technology has provided access to the human preimplantation embryo. The combination of these two developments will allow for genetic diagnosis before implantation. The success of this method as a diagnostic discipline in medicine requires the development of techniques that will reliably and specifically predict genetic outcome.

Karyotype analysis is not practical because it is limited to metaphase and requires a large number of cells. In situ hybridization will allow analysis of chromosome numbers in single cells or in small numbers of cells. Although the technique needs further improvement before becoming clinically applicable, this thesis shows the potential use of fluorescent in 
situ hybridization as a tool for preimplantation diagnosis (Chapter III). The use of FISH and PCR techniques will not only allow for the detection of gene defects, but of the chromosomal abnormalities (numerical and structural) as well.

The advancement of prenatal diagnosis to the preimplantation period will enable fertile patients at genetic risk (who would otherwise have had to opt for prenatal diagnosis at 10 or 16 weeks pregnancy) to use assisted reproduction and have only those preembryos replaced that are not carrying genetic diseases.

\section{What next?}

1. For human oocytes a technique needs to be developed to decrease the condensation grade of metaphase II chromosomes. In this way chromosome banding becomes possible and both, specific aneuploidy and structural aberrations can be diagnosed more accurately.

2. In situ hybridization with new chromosome specific probes will allow to study chromosomal nondisjunction rates in unselected spermatozoa.

3. More research is needed to evaluate the real percentage of chromosomal abnormalities in normally fertilized zygotes and preembryos after IVF.

4. Information should be obtained on the origin of the extra nucleus in triploid zygotes after IVF.

5. Further studies are needed on the development of biopsied preembryos.

6. Further refinement of molecular techniques will offer more insight in the structure and composition of gametes and preembryos at the DNA level.

\section{References}

Acosta AA, Oehninger S, Morshedi M, Swanson RJ, Scott R, Irianni F: Assited reproduction in the diagnosis and treatment of the male factor. Obstet Gynecol Surv $44: 1-18,1988$

Dokras A, Sargent IL, Ross C, Gardner RL, Barlow DH: Trophectoderm biopsy in human blastocysts. Hum Reprod 5:821-825, 1990

Dyban AP, Baranov VS: Cytogenetics of Mammalian Embryonic Development. Clarendon Press, Oxford (1987) 
Foulot H, Ranoux C, Dubuisson J-B, Rambaud D, Aubriot F-X, Poirot C: In vitro fertilization without ovarian stimulation: a simplified protocol applied in 80 cycles. Fertil Steril 52:617-621, 1989

Hardy K, Martin KL, Leese HJ, Winston ML, Handyside AH: Human preimplantation development in vitro is not adversely affected by biopsy at the 8-cell stage. Hum Reprod 5:708-714, 1990

Huisman GJ, Roozenburg BJ, Verhoef A, Alberda ATh, Leerentveld RA, Zeilmaker GH: An attempt to reduce the incidence of multiple pregnancies following IVF treatment. Hum Reprod 6, supp. 1:405, 1991

Ma S, Kalousek DK, Zouves C, Ho Yuen B, Gomel V, Moon YS: Chromosome analysis of human oocytes failing to fertilize in vitro. Fertill Steril 51:992-997, 1989

Macas E, Floersheim Y, Hotz E, Imthurn B, Keller PJ, Walt H: Abnormal chromosomal arrangements in human oocytes. Hum Reprod 5:703-707, 1990

Martin RH, Rademaker A: The frequency of aneuploidy among individual chromosomes in 6,821 human sperm chromosome complements. Cytogenet Cell Genet 53: 103:107, 1990

Meulenbroek GHM, Geraedts JPM: Parental origin of chromosome abnormalities in spontaneous abortions. Hum Genet 62:129-133, 1982

Michaeli G, Fejgin M, Ghetler $\mathbf{Y}$, Nun IB, Beyth Y, Amiel A: Chromosomal analysis of unfertilized oocytes and morphologically abnormal preimplantation embryos from an in vitro fertilization program. J In Vitro Fert Embryo Transfer 7:341-346, 1990

Ng S-C, Bongso A, Sathananthan H, Ratnam SS: Micromanipulation: its relevance to human in vitro fertilization. Fertil Steril $53: 203-219,1990$

Pellestor F: Frequency and distribution of aneuploidy in human female gametes. Hum Genet 86:283-288, 1991

Roesler M, Wise L, Katayama KP: Karyotype analysis of blighted ova in pregnancies achieved by in vitro fertilization. Fertil Steril 51:1065-1066, 1989

Rudak E, Jacobs PA, Yanagimachi R: Direct analysis of the chromosome constitution of human spermatozoa. Nature $274 ; 911-913,1978$

Schmiady H, Sperling $K$, Kentenich H, Stauber M: Prematurely condensed human sperm chromosomes after in vitro fertilization. Hum Genet 74:441-443, 1986 

Since the introduction of IVF in clinical practice the knowledge about events of fertilization and early preimplantation development has expanded enormously.

Although the female gametes are brought in close contact with high numbers of sperm cells, the process of in vitro fertilization does not result in a $100 \%$ success rate. The first signs of abnormal fertilization may be perceived at the time that the pronuclei should appear. If the number of pronuclei differs from two, a fertilization abnormality is likely. Fertilization failures may be due to a failure of the sperm cell to penetrate the oocyte. Abnormalities may also be related to the postfertilization development. IVF failures offer the opportunity to study the chromosomal contents of male and female gametes.

The first study was designed to investigate aspects of sperm penetration, fertilization and chromosome condensation in 150 oocytes considered to be unfertilized after IVF. At phase contrast microscopical observation all cells lacked pronuclei and did not show cleavage division. However, after Tarkowski's preparation method, $46(30.7 \%)$ appeared to show cytological evidence of fertilization. At least one-third of these cells (with development arrested before first cleavage) had chromosomal aberrations. An aneuploidy rate of $35 \%$ was found in unfertilized oocytes. The results of this study explain some of the failures of fertilization and of post-fertilization development (Chapter II).

The application of fluorescent in situ hybridization (FISH) was considered to be an alternative for chromosome studies with the important advantage of no dividing cells being necessary. This method allows gametes and non-dividing zygotes and preembryos to be studied cytogenetically. Using chemically modified chromosome-specific DNA probes, visualization was obtained performing immunocytochemistry to achieve a fluorescent stain on specific hybrids. Using a chromosome 1specific DNA probe, almost all spermatozoa gave a positive result, i.e., one hybridization signal per cell could be observed. Furthermore, it was possible to identify sperm cells with two spots, suggesting nondisjunction. Using a Y-specific DNA probe the percentages positive spermatozoa from normal males varied between $48.1 \%$ and $49.1 \%$. In a preembryo with four grossly haploid chromosome sets, three fluorescent spots were obtained with the Y-specific DNA probe, indicating the penetration of three spermatozoa (Chapter III).

In a related study FISH was used to detect the presence of chromosome 1 in spermatozoa from 32 normal males. It was possible to obtain hybridization signals in all but one semen samples. Positive hybridization reactions varied from $40 \%$ to over $90 \%$ for the different samples. To make sperm cells accessible for the molecules applied during the FISH 
method, incubation with dithiotreitol (DTT) was necessary. Duration of DTT treatment seemed to be of importance since both morphologically unaltered (undertreated) and overtreated sperm heads gave no analyzable results. Disomy for chromosome 1 was found in $0.67 \%$ of all accessible sperm cells (Chapter IV).

To investigate (im)maturity and (aneu)ploidy of human oocytes obtained after two different ovarian stimulation protocols, a retrospective study was designed. Unfertilized oocytes of 143 patients, of whom 65 were stimulated with clomiphene citrate (CC)/ human menopausal gonadotropin (hMG) and 78 were stimulated with gonadotropin-releasing hormone agonist (GnRH-a)/hMG, were investigated. Stimulation with GnRH-a/hMG, as compared to $\mathrm{CC} / \mathrm{hMG}$ stimulation, resulted in larger numbers of oocytes, a higher fertilization rate, and oocyte retrieval at a later average cycle day. Cytogenetic findings of immaturity were observed significantly more often in unfertilized oocytes after $\mathrm{CC} / \mathrm{hMG}$ stimulation than after GnRH-a/hMG stimulation. Aneuploidy findings were the same for both groups (Chapter V).

Finally, tripronuclear zygotes were studied cytogenetically. Successful analysis was possible of 42 specimens at the zygote stage and of 21 preembryos after first or second cleavage division. In the majority of zygotes $(88 \%)$ the expected triploidy was confirmed, whereas only $14 \%$ of preembryos had solely triploid cells. Therefore it was concluded that after tripolar cleavage division, many different types of mosaicism may originate from irregular chromosome distributions. Since the findings in individual blastomeres in preembryos resulting from multipronuclear zygotes do not reflect the genetic content of the whole preembryo, these preembryos are less suitable in a model system for preimplantion diagnosis.

The distribution of the sex chromosomal types (XXX, XXY, and XYY) were in agreement with theoretical expectations. Since in abortion material or in liveborn triploidy cases the XYY karyotype is hardly ever observed, most likely the $69, \mathrm{XYY}$ karyotype has a very high preembryonic mortality (Chapter VI). 
Vanaf de introductie van in vitro fertilisatie in de klinische praktijk, is de kennis omtrent het verloop van de bevruchting en de ontwikkeling van het embryo tijdens de preimplantatiefase sterk toegenomen.

Hoewel de vrouwelijke voortplantingscellen in nauw contact worden gebracht met grote aantallen zaadcellen, is het succespercentage van de in vitro bevruchtingsmethode niet $100 \%$. Op het moment dat geen twee pronucleï zichtbaar worden, is de aanwezigheid van een bevruchtingsafwijking aannemelijk. Sommige bevruchtingsafwijkingen zouden het gevolg kunnen zijn van het mislukken van de penetratie van de oöcyt door de zaadcel, terwijl andere verband zouden kunnen houden met het afwijkend verlopen van de ontwikkeling direct na de bevruchting. Door IVF is het mogelijk geworden de chromosomale inhoud van mannelijke en vrouwelijke gameten cytogenetisch te bestuderen.

Het eerste onderzoek was erop gericht bepaalde aspecten van de zaadcelpenetratie, de bevruchting en chromosomale condensatie te onderzoeken in 150 oöcyten waarvan werd aangenomen dat ze onbevrucht waren gebleven na IVF. Bij fasecontrastmicroscopisch onderzoek toonden deze cellen geen pronucleï en waren er geen tekenen van klievingsdeling. Echter, na de Tarkowski prepareermethode, bleken er $46(30.7 \%)$ cytologische tekenen van bevruchting te vertonen. Tenminste een derde van de cellen met een ontwikkeling geblokkeerd voor de eerste klievingsdeling, vertoonde chromosomale afwijkingen. In de onbevruchte oöcyten werd $35 \%$ aneuploidie waargenomen. De resultaten van dit onderzoek kunnen een aantal problemen die waargenomen worden bij de bevruchting en de ontwikkeling na de zygotevorming verklaren (Hoofdstuk II).

De toepassing van fluorescentie in situ hybridisatie (FISH) werd beschouwd als een alternatief voor chromosomenonderzoek met het belangrijke voordeel dat geen delende cellen nodig zijn. Op deze manier zouden gameten, niet-delende zygoten en pre-embryo's cytogenetisch onderzocht kunnen worden. Door gebruik te maken van chemisch gemodificeerde chromosoom specifieke DNA probes kon met behulp van immunocytochemische technieken een fluorescentiemicroscopisch zichtbaar signaal worden verkregen op plaatsen met specifieke hybridisatie. Door een probe te gebruiken die specifiek is voor chromosoom Nr. 1, gaven bijna alle zaadcellen een positief resultaat, d.w.z. dat éen hybridisatie signaal per cel werd waargenomen. Er werden enkele zaadcellen met twee signalen waargenomen, hetgeen verklaard kan worden door nondisjunctie. Na gebruik van een Y chromosoom specifieke probe lag het percentage positieve zaadcellen van normale mannen tussen $48,1 \%$ en $49,1 \%$. In een pre-embryo met vier min- of meer haploide chromosoom complementen, werden drie fluorescentie signalen ver- 
kregen na gebruik van de Y-specifieke DNA probe, ten teken van de penetratie door drie zaadcellen (Hoofdstuk III).

In een ander onderzoek werd FISH toegepast om de aanwezigheid van chromosoom Nr. 1 in zaadcellen van 32 mannen te onderzoeken. In op eén na alle monsters lukte het hybridisatiesignalen te verkrijgen. Positieve hybridisatiereacties varieerden van $40 \%$ in het ene, tot boven de $90 \%$ in een andere monster. Om de zaadcellen toegankelijk te maken voor de moleculen die nodig zijn tijdens de FISH methode was een incubatie met dithiotreitol (DTT) noodzakelijk. De duur van de DTT behandeling bleek van invloed, aangezien zowel morfologisch onveranderde (onderbehandelde) als overbehandelde zaadcellen geen analyseerbare resultaten opleverden. Disomie voor chromosoom Nr. 1 werd gevonden in $0,67 \%$ van alle toegankelijke zaadcellen (Hoofdstuk IV).

Om de (on)rijpheid en (aneu)ploïdie van humane oöcyten verkregen na twee verschillende ovariële stimulatieprotocollen te onderzoeken werd een retrospectief onderzoek verricht. Onbevruchte oöcyten van 143 patiënten, van wie er 65 waren gestimuleerd met clomipheencitraat (CC)/humaan menopausaal gonadotropine (hMG) en 78 met gonadotropine releasing hormoon-agonist (GnRH-a)/hMG werden onderzocht. Stimulatie met GnRH-a/hMG resulteerde in vergelijking met $\mathrm{CC} / \mathrm{hMG}$ stimulering in grotere aantallen oöcyten, een hoger bevruchtingspercentage, en leidde tevens tot een oöcytafname op een later tijdstip in de menstruele cyclus. Cytogenetische aanwijzingen voor onrijpheid werden significant vaker waargenomen in onbevruchte oöcyten na $\mathrm{CC} / \mathrm{hMG}$-stimulatie dan na GnRH-a/hMG-stimulatie. Aneuplö̈die kwam even vaak voor in beide groepen (Hoofdstuk V).

Tenslotte werden tripronucleaire zygoten cytogenetisch bestudeerd. Een volledige analyse lukte bij 42 zygoten, terwijl 21 pre-embryo's na de eerste of tweede klievingsdeling onderzocht konden worden. In de meerderheid van de zygoten ( $88 \%$ ) kon de verwachte triploïdie bevestigd worden, terwijl slechts $14 \%$ van de pre-embryo's uitsluitend triploïde cellen bezat. Daarom kon worden geconcludeerd dat na een tripolaire klievingsdeling, door ongelijke verdeling van de chromosomen, veel verschillende typen mosaïcisme gevonden kunnen worden. Het feit dat de bevindingen van individuele blastomeren van pre-embryo's die ontstaan zijn uit multipronucleaire zygoten niet de genetische inhoud van het hele pre-embryo weerspiegelen, maakt dit materiaal minder goed bruikbaar als model voor preimplantatie diagnostiek.

De verdeling van de geslachtschromosomale typen (XXX, XXY en XYY) was in overeenstemming met de theoretische verwachtingen. Aangezien in abortus materiaal en bij levendgeborenen met triploïdie het XYY karyotype uiterst zelden wordt waargenomen, mag worden aangenomen dat het $69, \mathrm{XYY}$ karyotype een zeer hoge (pre)embryonale mortaliteit vertoont (Hoofdstuk VI). 


\section{Dankwoord}

Zonder de hulp van anderen was het niet mogelijk geweest om het onderzoek te doen welk heeft geleid tot publicatie van dit proefschrift. Dank aan allen die op enigerlei wijze een steentje hebben bijgedragen aan dit werk en met name diegenen die van dichtbij betrokken waren bij de totstandkoming van dit proefschrift:

Allereerst mijn promotores, Prof. Dr. J. Geraedts en Prof. Dr. J. Evers, die vanaf het begin net zo enthousiast waren over het onderzoek als de schrijver van dit boekje. Beiden wisten mij op hun eigen manier te motiveren en te stimuleren.

John Dumoulin, die op een plezierige manier vaak de juiste kritiek leverde op zowel de onderzoeksresultaten alsook op de manuscripten. Zijn suggesties en adviezen waren essentieel bij dit resultaat.

Petra Nederlof en Sylvia van der Flier, zij gaven mij veel praktische tips voor de uitvoering van in de in situ hybridisatie methode.

Henk Meyer was altijd behulpzaam als vraagbaak op het gebied van de moleculaire genetica.

Edith Coonen voor het verrichten van een groot gedeelte van de werkzaamheden van één van de hoofdstukken van dit proefschrift.

Marijke Bras, Wiel Debie, Rosie Ignoul-Vanvuchelen, Roselie Jongbloed en Frank Kornips van wie ik steun kreeg vanaf het prepareren tot aan het analyseren.

Francis van der Lubbe die zelfs de goede foto's nog iets beter maakte. De leden van de beoordelingscommissie, Prof. Dr. P.J. Brombacher, Prof. Dr. J.W. Arends, Prof. Dr. J. Drukker, Mw. Prof. Dr. C. Heyting en Prof. Dr. G.H. Zeilmaker, voor hun bereidheid het manuscript te beoordelen. Medewerkers bibliotheek Biomedisch Centrum voor de vaak snelle hulp bij geraadpleegde literatuur.

Medewerkers ICA Biomedisch Centrum, gelukkig hadden zij meer verstand van computers.

Lionne maakte het mij mogelijk zoveel tijd te investeren in het onderzoek als nodig was. Lieve Lionne, jouw hulp, geduld en steun op alle fronten waren onmisbaar. 



\section{Curriculum Vitae}

Math Pieters werd geboren op 29 november 1959 in Heer, thans gemeente Maastricht. Hij behaalde zijn diploma Atheneum-B in 1979 (St. Maartenscollege, Maastricht). Hij studeerde geneeskunde aan de Rijksuniversiteit Limburg. Het doktoraal examen werd afgelegd in januari 1985 en het arts-examen werd behaald in oktober van dat jaar.

Van september 1985 tot maart 1988 was hij in deeltijd werkzaam als universitair docent bij de vakgroep Genetica/Celbiologie (RL). Deze functie werd van november 1985 tot juli 1986 gecombineerd met een aanstelling bij de vakgroep Economie van de Gezondheidszorg (RL) (project: "in vitro fertilisatie technology assessment"). Van juli 1986 tot maart 1988 was hij tevens werkzaam als arts in algemene dienst bij de Stichting Klinische Genetica Limburg t.b.v. de prenatale diagnostiek. Vanaf maart 1988 is de schrijver als wetenschappelijk onderzoeker bij de vakgroep Genetica/Celbiologie (RL) werkzaam geweest als medewerker aan het door NWO gefinancierde project: "Genetisch onderzoek van humane oöcyten en pre-implantatie embryo's". 


\section{Papers}

Pieters MHEC, Geraedts JPM, Dumoulin JCM, Evers JLH, Bras M, Kornips FHAC, Menheere PPCA; Cytogenetic analysis of in vitro fertilization (IVF) failures. Human Genet 1989; Vol 81:367-370

Pieters MHEC, Geraedts JPM, Dumoulin JCM, Evers JLH, Offermans JPM; De bijdrage van chromosomale afwijkingen aan mislukte in vitro fertilisatie. Ned Tijdsch v Obstet Gynaecol 1989; Vol 102:394-398

Pieters MHEC, Geraedts JPM, Meyer H, Dumoulin JCM, Evers JLH, Jongbloed RJE, Nederlof PM, van der Flier S; Human gametes and zygotes studied by non-radioactive in situ hybridization. Cytogenet Cell Genet 1990; Vol 53:15-19

Madan K, Pieters MHEC, Kuyt LP, van Asperen C, de Pater JM, Hustinx ThWJ, Breed ASPM, Hamers G, Gerssen KJB, van Hemel JO; Paracentric inversion inv (11) $(\mathrm{q} 21 ; \mathrm{q} 23)$ : a Dutch inversion ? Human Genet 1990; Vol 85:15-20

Dumoulin JCM, Evers JLH, Offermans JPM, Bras M, Pieters MHEC, Geraedts JPM; Human in vitro fertilization using spermatozoa capacitated in hyperosmotic media. Gynecol Obstet Invest 1990; Vol $30: 165-168$

Coonen E, Pieters MHEC, Dumoulin JCM, Meyer H, Evers JLH, Ramaeckers FCS, Geraedts JPM; Non-isotopic in situ hybridization as a method for non-disjunction studies in human spermatozoa. Mol Reprod \& Dev 1991; Vol 28:18-22

Dumoulin JCM, Menheere PPCA, Evers JLH, Kleukers APG, Pieters MHEC, Bras M, Geraedts JPM; The effects of endotoxins on gametes and preimplantation embryos cultured in vitro. Human Reprod 1991, Vol $6: 730-734$

Enginsu ME, Dumoulin JCM, Pieters MHEC, Bras M, Evers JLH, Geraedts JPM; Evaluation of human sperm morphology using strict criteria after diff-quik staining: correlation of morphology with fertilization in vitro. Human Reprod 1991, Vol 6:854-858 
Pieters MHEC, Dumoulin JCM, Engelhart CM, Bras M, Evers JLH, Geraedts JPM; Immaturity and aneuploidy in human oocytes after different stimulation protocols. Fertil Steril 1991; Vol 56:306-310

Pieters MHEC, Dumoulin JCM, Ignoul-Vanvuchelen RCM, Bras $\mathrm{M}$, Evers JLH, Geraedts JPM; Triploidy after in vitro fertilization: cytogenetic analysis of human zygotes and embryos J IVF \& ET 1991, in press

Dumoulin JCM, Evers JLH, Bras M, Pieters MHEC, Geraedts JPM: Positive effect of taurine on preimplantation development of mouse embryos in vitro. $\mathrm{J}$ Reprod \& Fert, in press

\section{Abstracts}

Dumoulin JCM, Pieters MHEC, Geraedts JPM; Chromatide breaks in chromosomes of human oocytes which remained unfertilized after IVF. ESHRE congress, Brussels. Human Reprod 1986; Vol. 1, s198

Pieters MHEC, Bras M, Dumoulin JCM, Evers JLH, Geraedts JPM, Nederlof PM, van der Ploeg M; Chromosome studies in a human IVF programme. ESHRE congress, Barcelona. Human Reprod 1988; Vol. 3, s370

Pieters MHEC, Dumoulin JCM, Ignoul-Vanvuchelen RCM, Bras M, Evers JLH, Geraedts JPM: Cytogenetic studies of triploid human zygotes and embryos. ESHRE congress, Milaan. Human Reprod 1990; Vol. 5, s27

Pieters MHEC, Dumoulin JCM, Engelhart CM, Bras M, Evers JLH, Geraedts JPM; Hormonal influence on oocyte maturation; a cytogenetic investigation. IVF world congress, Parijs. Human Reprod 1991; Vol. 6, s550

Dumoulin JCM, Evers JLH, Land JL, Bras M, Pieters MHEC, Geraedts JPM; Taurine stimulates mouse embryonic development in vitro. IVF world congress, Parijs. Human Reprod 1991; Vol. 6, s154

Dumoulin JCM, Bras M, Land JL, Pieters MHEC, Enginsu ME, Evers JL; A high number of inseminating sperm in human in vitro fertilization is detrimental for the subsequent embryonic development in vitro. ESHRE congres, Parijs. Human Reprod 1991; Vol. 6, s77 